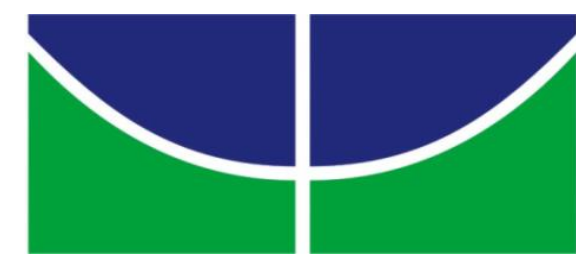

UNIVERSIDADE DE BRASÍLIA

Instituto de Ciências Biológicas

Instituto de Física

Instituto de Química

Faculdade UnB Planaltina

Programa de Pós-Graduação em Ensino de Ciências

Mestrado Profissional em Ensino de Ciências

ENSINO- APRENDIZAGEM DO CONCEITO DE "CÉLULA VIVA": PROPOSTA DE ESTRATÉGIA PARA O ENSINO FUNDAMENTAL.

JACQUELINE ALVES ARAÚJO FRANÇA

BRASÍLIA- DF 


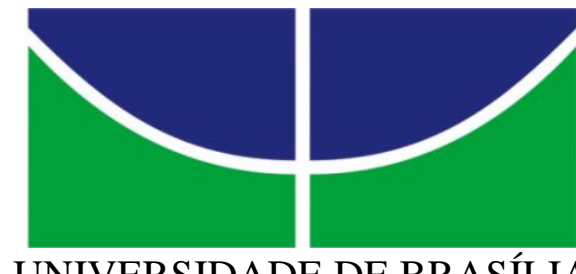

UNIVERSIDADE DE BRASÍLIA

Instituto de Ciências Biológicas

Instituto de Física

Instituto de Química

Faculdade UnB Planaltina

Programa de Pós-Graduação em Ensino de Ciências

Mestrado Profissional em Ensino de Ciências

\section{ENSINO- APRENDIZAGEM DO CONCEITO DE "CÉLULA VIVA": PROPOSTA DE ESTRATÉGIA PARA O ENSINO FUNDAMENTAL.}

JACQUELINE ALVES ARAÚJO FRANÇA

Dissertação sob a orientação da Prof. a Dra Maria Márcia Murta e apresentado à banca examinadora como requisito parcial à obtenção do Título de Mestre em Ensino de Ciências, pelo Programa de Pós-Graduação em Ensino de Ciências da Universidade de Brasília.

BRASÍLIA- DF

Junho

2015 


\section{FICHA CATALOGRÁFICA}

FRANÇA, Jacqueline A. Araújo.

ENSINO- APRENDIZAGEM DO CONCEITO DE "CÉLULA VIVA": PROPOSTA DE ESTRATÉGIA PARA O ENSINO FUNDAMENTAL/ UnB, Brasília, 2015.

136 P. (Dissertação)

Dissertação (Mestrado) - Universidade de Brasília. Instituto de Biologia/ Física/Química.

Programa de Pós-Graduação em Ensino de Ciências.

1. Célula viva. 2. Conceito Científico. 3. Concepções Prévias. 4. Pensamento Sistêmico. 5. Ensino de Ciências - Pesquisa - Teoria do Perfil do Conceitual 
FolHA de APROVAÇÃo

JACQUELINE ALVES ARAÚJO FRANÇA

\section{ENSINO- APRENDIZAGEM DO CONCEITO DE "CÉLULA VIVA": PROPOSTA DE ESTRATÉGIA PARA O ENSINO FUNDAMENTAL.}

Dissertação apresentada à banca examinadora como requisito parcial à obtenção do Título de Mestre em Ensino de Ciências pelo Programa de Pós-Graduação em Ensino de Ciências (PPGEC) da Universidade de Brasília (UnB).

Aprovada em 16 de junho de 2015.

BANCA EXAMINADORA

Prof. ${ }^{a}$ Dr. ${ }^{a}$ Maria Márcia Murta- IQ/UnB

(Presidente)

Prof. Dr. Marcelo Rodrigues dos Santos-UNIP

(Membro Titular)

Prof. Dr. ${ }^{a}$ Maria de Nazaré Klautau-IB/UnB

(Membro Titular)

Prof. Dr. Ricardo Gauche- IQ/ UnB

(Membro Suplente) 
Para meu esposo Marcos, meus filhos Bruno e Rafael, que entre tantas coisas, nunca me deixaram esquecer que o despertar para o conhecimento, mesmo quando precisamos (e queremos) fazer dissertação, jamais substituirá o prazer de estar com eles. 


\section{AGRADECIMENTOS}

A Prof. a Maria Márcia Murta, minha orientadora querida, por me apresentar nova $e$ significativa forma de olhar/conceber o processo de ensino-aprendizagem e pelas orientações lúcidas e precisas que me tornaram mais confiante perante o meu próprio modo de aprender.

Ao meu chefe imediato coronel José Nicolau Saad de Carvalho que facilitou e apoiou minha pesquisa no cotidiano escolar e ainda disponibilizou tempo para dialogar sobre inúmeras questões quando precisei

Aos colegas do 8 a ano, pelo carinho, interesse e compromisso demonstrados durante 0 percurso de minha pesquisa.

A equipe de professores do Programa de Pós-Graduação de Ensino de Ciências, pelas sugestões relevantes à pesquisa, pelo carinho demonstrado sempre, pela atitude acolhedora e por demonstrar que sempre há alternativas no ambiente profissional e na educação como um todo.

E por fim, a minha mãe que infelizmente partiu alguns dias antes que eu fizesse a seleção do mestrado, mas cujo legado de persistência, abnegação e encorajamento encontraram eco nessa pesquisa. 
Resumo

A pesquisa aqui apresentada buscou auxiliar professores do $8^{\circ}$ ano do ensino fundamental a perceber as dificuldades apresentadas pelos alunos na construção do conceito de célula viva com um olhar mais sistêmico, e teve como objetivo maior desenvolver uma estratégia de ensino nesse sentido. A perspectiva teórica adotada situou a trajetória da construção do conceito de célula pelo aluno do $8^{\circ}$ ano, à luz da Teoria do Perfil Conceitual. A teoria estabelece que um único conceito possa estar disperso entre vários tipos de concepções, sendo que o aluno não precisa abandonar as concepções trazidas da sua vivência. Quanto à perspectiva metodológica, foi construído um itinerário investigativo pautado na pesquisa qualitativa, legitimada por meio de observação e questionários. Os questionários buscaram explicitar as concepções prévias dos alunos sobre o conceito de célula e como alguns obstáculos podem inviabilizar a construção dos significados desses conceitos científicos coerentes com aquele aceito atualmente. A aplicação de questionários também tentou orientar o professor no sentido de avaliar se a estratégia de ensino aplicado tinha facilitado a apreensão de conceitos celulares. Já a observação transcorreu durante todo o processo. O universo pesquisado foi de 165 alunos do $8^{\circ}$ ano. A pesquisa centrou-se em um colégio público federal. Os resultados obtidos mostraram que as concepções prévias foram bem heterogêneas. Embora a maioria apresentasse algum potencial de compartilhamento social, os resultados também indicaram que as principais inconsistências encontradas foram quanto à morfologia, às funções e aos tipos de células, além do desconhecimento de conceitos básicos, dado o expressivo número de respostas em branco. Em função das constatações obtidas, foi elaborado um módulo didático de apoio ao docente do $8^{\circ}$ ano do ensino fundamental, no qual pudemos indicar alternativas ao professor de como melhor lidar com as dificuldades do aluno, na construção de conceitos tão essenciais ao estudo do corpo humano como a célula viva.

Palavras-chave: célula viva; conceito científico; concepções prévias; pensamento sistêmico, Teoria do Perfil Conceitual 


\begin{abstract}
The research presented here had the goal of helping eighth-grade teachers to perceive the difficulties experienced by students in building the concept of living cell with a more systemic approach, and had as an even higher goal to develop a corresponding teaching strategy. The theoretical framework considered the steps in the building of the concept of living cell by eighth-graders according to Conceptual Profile Theory. The theory establishes that one given concept may be found divided into various types of other concepts, and the students do not have to give up the concepts brought by their own experience. As to the methodology, an investigation was conducted based on qualitative research and supported by observation and questionnaires. The questionnaires aimed at highlighting students' previous ideas about the concept of cell, as well as how some obstacles may hinder the building of the meaning of such scientific concepts in relation to the concept currently accepted. The questionnaires also tried to help the teacher to decide whether the teaching strategy used had facilitated the understanding of cellular concepts. The observation was present throughout the whole process. The universe of the research was made up of 165 eighth-grade students, and the research was conducted in a federal public school. The results showed that previous concepts were very heterogeneous. Although the majority contained some potential for social sharing, the results also indicated that the main inconsistencies encountered concerned morphology, function and types of cells, as well as the ignorance of basic concepts, given the expressive number of blank answers. Based on the results of the research, a supporting learning module was constructed to help the eighth-grade teacher, pointing out alternatives as to how the teacher could best deal with students' difficulties in building concepts that are so essential to the study of the human body such as the living cell.
\end{abstract}

Key words: living cell, scientific concept, previous conceptions, systemic thinking, Conceptual Profile 


\section{LISTA DE ABREVIATURAS E SIGLAS}

$\begin{array}{ll}\text { AE } & \text { Avaliação de Estudo } \\ \text { CM } & \text { Colégio Militar } \\ \text { CMB } & \text { Colégio Militar de Brasília } \\ \text { CFB } & \text { Ciências Físicas e Biológicas } \\ \text { DECEx } & \text { Departamento de Ensino e Cultura do Exército } \\ \text { DCN } & \text { Diretrizes Curriculares Nacionais } \\ \text { EF } & \text { Ensino Fundamental } \\ \text { EM } & \text { Ensino médio } \\ \text { ENEM } & \text { Exame Nacional do Ensino Médio } \\ \text { IAP } & \text { Instrumento Parcial de Avaliação } \\ \text { LDBN } & \text { Lei de Diretrizes e Bases da Educação Nacional } \\ \text { LaBiSisMi } & \text { Laboratório de Biologia Sistêmica de Microrganismos } \\ \text { MEC } & \text { Ministério da Educação e Cultura } \\ \text { PSD } & \text { Plano de Sequência Didática } \\ \text { PPGEC } & \text { Programa de Pós-Graduação de Ensino de Ciências } \\ \text { QN } & \text { Questão Norteadora } \\ \text { SCMB } & \text { Sistema Colégio Militar do Brasil } \\ \text { SAEB } & \text { Sistema de Avaliação da Educação Básica } \\ \text { TPC } & \text { Teoria de Perfil Conceitual } \\ \text { USP } & \text { Universidade de São Paulo } \\ \text { UnB } & \text { Universidade de Brasília } \\ \end{array}$




\section{LISTA DE FIGURAS}

Figura 1- Interações moleculares para formação de um indivíduo complexo................ 24

Figura 2- Sistema de Endomembranas celular............................................................. 25

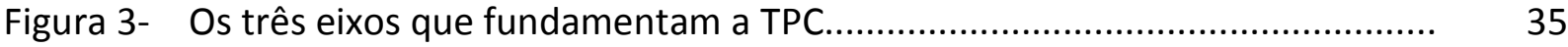

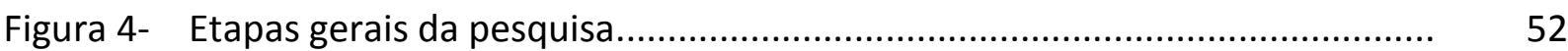

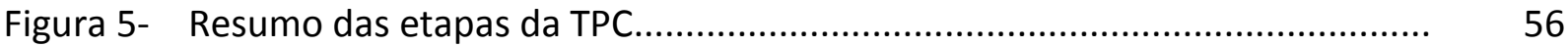




\section{LISTA DE QUADROS}

Quadro1- Conceitos avaliados........................................................................ 53

Quadro 2- Resumo do Percurso Metodológico........................................................ 58

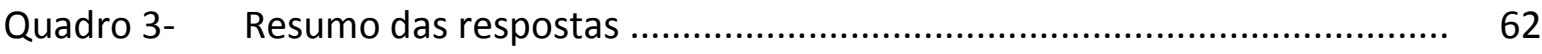

Quadro 4- Respostas dos alunos à primeira questão............................................. 63

Quadro 5- $\quad$ Respostas dos alunos à quinta questão.............................................. 67

Quadro 6- $\quad$ Linha do tempo mostrando a evolução dos conceitos celulares............... 74

Quadro 7- Respostas dos alunos a primeira questão do pós-teste......................... 77

Quadro 8- $\quad$ Respostas dos alunos a segunda questão do pós-teste......................... 78

Quadro 9- $\quad$ Respostas dos alunos a terceira questão do pós-teste........................... 79

Quadro 10 Resposta dos alunos a quarta questão do pós-teste............................... 80 


\section{SUMÁRIO}

INTRODUÇÃ

1 ITINERÁRIO DELINEADO PARA A PESQUISA................................................. 19

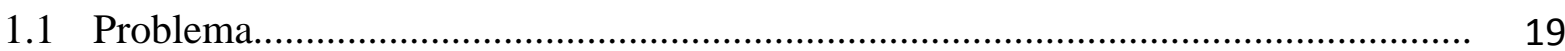

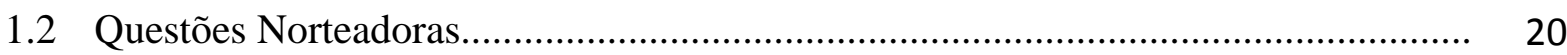

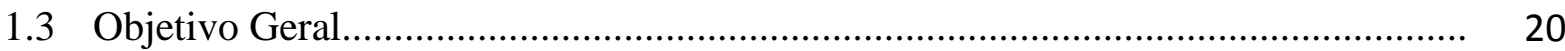

2 A CONSTRUÇÃO DO CONCEITO CIENTÍFICO SOBRE CÉLULA SOB A 21 PERSPECTIVA DA TEORIA DO PERFIL CONCEITUAL.

2.1 Desenvolvimento da Cognição Individual............................................................ 35

2.2 História e Filosofia da Ciência.......................................................................... 39

2.3 Desenvolvimento social das ideias em sala de aula............................................ 42

3 REFLEXÕES SOBRE O CONCEITO DE CÉLULA............................................ 47

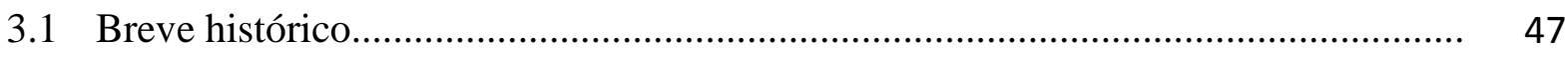

4 METODOLOGIA............................................................................................ 52

4.1 Local da pesquisa, população de estudo e procedimentos..................................... 56

4.2 Desenvolvimento em sala de aula................................................................... 58

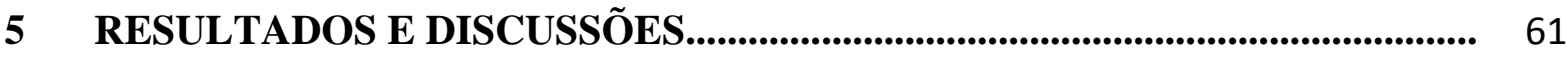

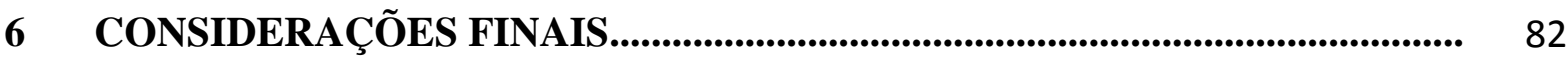

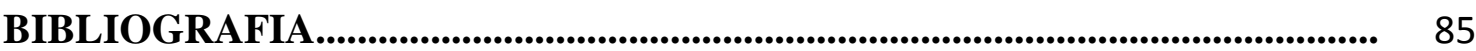

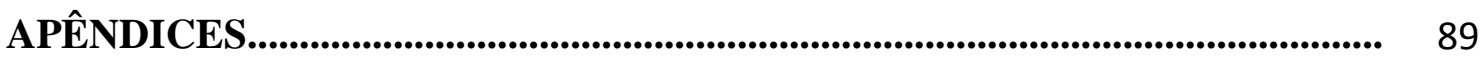

Apêndice 1- Termo de Consentimento livre e esclarecido....................................... 90

Apêndice 2- Pré-teste.................................................................................... 91

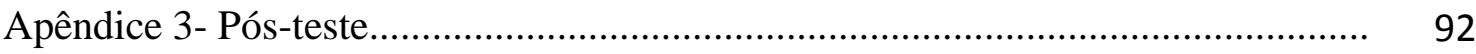

Apêndice 4- Proposta de Intervenção....................................................................... 93

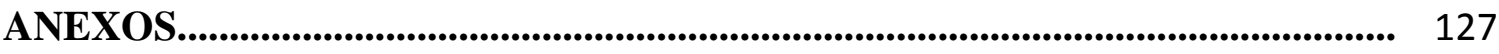

Anexo 1- Texto: Construindo conhecimento científico em sala de aula.................... 128 


\section{INTRODUÇÃO}

Algumas inquietações relacionadas ao processo ensino-aprendizagem surgiram após meu primeiro contato com alunos do $8^{\circ}$ ano do ensino fundamental (EF). A angústia mais presente era perceber a dificuldade dos estudantes em consolidar o entendimento de um conceito primordial para o estudo do corpo humano: a célula viva. Escolhemos trabalhar com essa temática no $8^{\circ}$ ano por ser a célula uma ponte ao estudo propriamente dito do corpo humano, embora o aluno já tenha tido alguma noção ao estudar o reino monera no 7oano do $\mathrm{EF}$, mas com a perspectiva geral dos reinos.

Embora reconheçamos o papel crucial das células mortas em diferentes tecidos vegetais e mesmo animais, como por exemplo, os esclerênquimas: formado por células mortas, com parede celular muito grossa e lignificada (fibrosa) e o suberoso: tecido protetor que se forma no caule e na raiz das plantas lenhosas a partir da morte da parte externa da epiderme, portanto, composta por células mortas, desprovidas de ar e com a parede impregnada de uma substância especial, a suberina, daremos mais ênfase ao estudo das células humanas vivas, por entender que são elas que realizam as funções fundamentais dos seres vivos, como reprodução, crescimento, alimentação, movimentação, reação a estímulos externos e respiração e por trabalharmos com corpo humano no $8^{\circ}$ ano.

Essas inquietações levaram-me a buscar a documentação legal que baliza o processo de ensino do Sistema Colégio Militar do Brasil (SCMB) ${ }^{1}$. Doze colégios ${ }^{2}$ fazem parte desse sistema, localizados em diferentes regiões do Brasil. Trabalhei em três deles, sempre no $8^{\text {o }}$ ano do Ensino Fundamental, intercalado com o $1^{\mathrm{o}}$ ano do ensino médio (EM), quando se estuda a morfologia e a fisiologia celular em um grau mais aprofundado.

Em meio a essas inquietações, tive contato com o Plano de Sequência Didática (PSD). O PSD apresenta, em sua estrutura documental, as competências, as habilidades e os descritores previstos para todo EF e EM do SCMB. A proposta filosófica da disciplina de Ciências exposta no documento diz que:

O estudo das Ciências Naturais, a partir do conhecimento científico-tecnológico historicamente acumulado pela humanidade, busca a compreensão dos fenômenos naturais. Dentro dessa perspectiva, as Ciências Físicas e Biológicas devem fornecer condições para o aluno reconstruir a relação ser humano/natureza visando ao desenvolvimento de uma consciência individual, social e planetária[...] (PLANO DE

\footnotetext{
${ }^{1}$ Os Colégios Militares supracitados seguem um rigoroso padrão de normas, de doutrinas e de regimentos uniformemente seguidos por todos os 12 Colégios.

${ }^{2} \mathrm{O}$ universo de alunos atualmente no sistema gira em torno de 15 mil estudantes.
} 
SEQUÊNCIAS DIDÁTICAS - $8^{\circ}$ ano / Ensino Fundamental Área: Ciências da Natureza e suas Tecnologias-2014, p. 2).

O PSD está fundamentado na Portaria $N^{0} 137$, de 28 de fevereiro de 2012, do Comando do Exército, cuja referência é a Lei Federal Ordinária n ${ }^{\circ}$ 9.394, de 20 de dezembro de 1996-Lei de Diretrizes e Bases do Ensino Nacional (LDBEN). As práticas didáticopedagógicas do SCMB subordinam-se às normas e prescrições do Sistema de Ensino do Exército e, ao mesmo tempo, obedecem à LDBEN (1996), principal referência que estabelece os princípios e as finalidades da educação no País. O PSD (2012, p. 8) explicita como competência C9, "Compreender a vida como a manifestação de sistemas organizados e integrados, reconhecendo-se como organismo..." E a habilidade H38 do mesmo documento é assim descrita: “Compreender a organização celular como estrutura básica de todos os seres vivos comparando a organização e o funcionamento de diferentes tipos de células".

Nesse sentido, o documento aponta uma preocupação em promover a compreensão de conteúdos conceituais como célula viva, estando em total consonância com os documentos oficiais em vigor, tais como as Diretrizes Curriculares Nacionais (DCN) de 2013, que citam a necessidade de se estabelecerem critérios para a seleção dos conteúdos, de acordo com os objetivos gerais da área e acrescenta que o século XXI presencia um intenso processo de criação científica, inigualáveis há tempos anteriores.

Nessa perspectiva, a associação entre ciência e tecnologia se estreita, assegurando a parceria em resultados, como por exemplo, a biotecnologia, capaz de modificar novas espécies vegetais e animais com características previamente estipuladas que alcançam a todos, ainda que, nem sempre, o leigo consiga entender sua amplitude.

Não podemos falar em engenharia genética, sem nos preocuparmos com a fundamentação de conhecimentos científicos como a célula- e acreditarmos que os conceitos construídos, ainda nos anos iniciais do EF, têm grandes perspectivas de sucesso, quando solicitados em anos posteriores, incluindo o ensino superior; evidentemente, respeitando o processo de amadurecimento intelectual e cronológico do aluno.

No currículo escolar dos colégios militares o estudo da célula acontece no início do ensino fundamental no $6^{-}$ano, de forma muito rudimentar, associado a doenças do meio ambiente e, a partir daí, a cada ano, os alunos têm a oportunidade de aprofundar os conhecimentos, visto que este assunto permeia todo o estudo de Ciências no Ensino Fundamental e de Biologia no Ensino Médio. De acordo com Palmero e Moreira (2001, p. 26): “A célula para o processo de ensino em Biologia é um conceito chave na organização do 
conhecimento biológico. No entanto para os alunos é uma entidade complexa e abstrata que se constrói em suas mentes”.

Hoje, o avanço dos estudos da anatomia humana, associada à fisiologia, possibilitounos enxergar as partes internas do corpo humano e também as relações entre essas partes. Sabe-se que cada órgão, cada sistema tem funções específicas, mas a capacidade de realizá-las depende da participação de outros sistemas. Essa dependência mostra a integração dos sistemas do corpo humano, tendo como base a própria célula. Bastos (1992, p. 67) afirma que "A aquisição de uma ideia significativa de célula exige que o aluno conheça os processos celulares fundamentais [...] e estabeleça relações entre estes processos e as propriedades diretamente observáveis do ser vivo" como tecidos e órgãos.

Nesse sentido, defendemos ainda a necessidade de o professor perceber a emergência do pensamento sistêmico em sua prática, compreender o conhecimento sob a perspectiva da complexidade, lançando seu olhar, não somente para a unidade celular isoladamente, mas também para o indivíduo como um todo, considerando o contexto e as relações aí estabelecidas, "relacionando os conteúdos da sala com questões mais amplas como sociais e ambientais" (MURTA, 2013, p.4).

As DCN (BRASIL, 2013, p.147) preconizam a necessidade do pensamento sistêmico em toda educação, quando afirma que a visão sistêmica implica "reconhecer as conexões intrínsecas entre Educação Básica e Educação Superior; entre formação humana, científica, cultural e profissionalização". Um exemplo desse pensamento direcionado especificamente à biologia é encontrado no texto do LaBiSisMi (Laboratório de Biologia Sistêmica de Microrganismos) da Universidade de São Paulo (USP) onde se lê que

\footnotetext{
A Biologia Sistêmica é o ramo da ciência que busca entender os organismos biológicos em todos os seus níveis, desde a caracterização de suas partes constituintes (genes, RNAs, proteínas, metabólitos), a elucidação das interconexões entre os distintos membros dessas redes de interações, até a compreensão do organismo como um todo.

Disponível em: <http://labisismi.fmrp.usp.br/index.php/br/biologiasistemica〉. Acesso em: 9 ago. 2014
}

Nosso interesse na pesquisa teve origem, justamente, nas observações das repetições com que os alunos utilizavam o conceito de célula, de forma fragmentada e desconexa ao estudo do corpo humano, por vezes numa linguagem pouco científica, como se células e organismo fossem entes dissociados. Percebemos que os estudantes, apesar de resolverem alguns problemas que envolviam conceitos celulares em momentos específicos, tendiam a apresentar dificuldades em generalizar explicações e buscar um referencial conceitual mais 
consolidado quando solicitados em outros momentos do ano letivo, na qual precisaram fazer alguma correlação com o que já haviam visto.

Segundo Mortimer (2006.p. 52) "uma estratégia de ensino...deveria auxiliar estudantes a superarem suas dificuldades de generalizações” Para o autor a grande dificuldade é que muitos estudantes não passam para o plano dos princípios e das explicações, em consequência ele não tentam generalizar as explicações para os fenômenos diversos.

O referencial teórico de escolha, para nortear nosso trabalho, foi a Teoria de Perfil Conceitual (TPC), desenvolvida por Mortimer (2006). Buscamos uma teoria que desse outro olhar à realidade educacional atual, ou seja, que pensasse o estudante em toda sua complexidade e, de forma prática, considerasse como esse aluno aprende melhor. Entendemos que a TPC aponta essa direção.

A TPC procura compreender a convivência, num mesmo indivíduo, de várias representações de um mesmo conceito, desde aquelas de senso comum até as científicas. Essa abordagem avalia as concepções prévias dos estudantes em sala de aula e pressupõe que essas concepções alternativas não sejam necessariamente abandonadas ao longo do processo de ensino em detrimento de aquisições de concepções científicas, mas sim que possam conviver com as anteriores, podendo ser utilizadas em contextos convenientes.

Mortimer (2006, p.30) faz uma revisão crítica dos pressupostos psicológicos e filosóficos das estratégias de ensino, para mudanças conceituais recorrentes na literatura (por exemplo, POSNER, 1982). Segundo ele o modelo de mudança conceitual parece ainda prevalecer em muitos artigos a respeito do tema, em que prepondera a expectativa de que as ideias do aluno deverão ser abandonadas e/ou subsumidas no processo de ensino.

Ainda criticando tais pressupostos, Mortimer (1996, p.37) aponta o grande número de estratégias de ensino-aprendizagem que se balizam na expectativa de que as ideias prévias dos estudantes devam ser abandonadas, para dar lugar a uma eventual superação da contradição (sejam ideias conflitantes sejam discrepantes).

A grande dificuldade dos professores apresentada por Mortimer (1996), em seus estudos, é o desconhecimento de que aprender ciências envolve a iniciação dos estudantes em uma nova maneira de pensar e explicar o mundo natural. É o que Driver (1999) chama em última análise de "enculturação 3 ".

\footnotetext{
${ }^{3}$ Mortimer (2006), Driver (1999) usam a palavra enculturação para exprimir o processo pelo qual uma pessoa entra numa cultura diferente da sua, adquirindo, por exemplo, conceitos, linguagens e certas práticas da cultura científica.
} 
Desde 2011, a rede de ensino, no qual exerço o magistério, fez a opção de direcionar seu projeto pedagógico para o ensino por competências. Todo o Sistema de Ensino do Departamento de Educação e Cultura do Exército (DECEx), órgão que cuida dos assuntos pertinentes ao ensino no âmbito do Exército, está baseado nessa premissa. Essa migração para o ensino por competências e habilidades se deu pelo entendimento de que há necessidade de adequação do ensino frente a um novo aluno recebido no próprio sistema, cujo perfil vem mudando nas últimas décadas.

Essa mudança, segundo o DECEx, se justifica por uma abordagem pedagógica mais alinhada com as grandes nações e com as teorias de aprendizagem mais atuais preconizadas pelo MEC. A TPC se adequa, perfeitamente, a essa visão. As políticas educacionais brasileiras para a educação básica priorizam as metodologias ativas; ou seja, aquelas que estimulam a crítica e reflexão no processo de ensino e aprendizagem. O DECEx está atento a isso, e também está alinhada com as importantes avaliações de larga escala para a educação no Brasil, entre elas o Sistema de Avaliação da Educação Básica (Saeb), a Prova Brasil e o Exame Nacional do Ensino Médio (ENEM). (BRASIL, 2013).

Esse trabalho apresenta um estudo realizado em um ambiente que utiliza os pressupostos presentes nessa teoria, acreditando que a partir dele, como instrumento de ensino, zonas conceituais sobre célula possam ser identificadas e trabalhadas em sala de aula, embora o aluno não necessariamente tenha de abandonar as suas concepções ao aprender novas ideias científicas, mas torná-las mais conscientes, ou seja, saber que o uso de determinadas concepções pode ser limitado em alguns contextos. Em outras palavras, ele pode apresentar uma forma de pensar não científica em seu dia a dia, mas sabendo que, em um contexto científico, aquela concepção pode ser insuficiente.

Essas percepções, associadas à necessidade de conhecer uma maneira de colaborar com a aprendizagem dos alunos, tomaram corpo na pesquisa iniciada no mestrado profissional do Programa de Pós-Graduação de Ensino de Ciências (PPGEC) da Universidade de Brasília.

Diante do exposto e da tendência curricular de dar um novo olhar para o aluno ao estudar ciências, preconizado por vários documentos oficiais, (BRASIL, 2013) e por toda documentação legal do SCMB, em que o currículo é organizado possibilitando uma interação entre a ciência e o cotidiano do aluno, a escolha da TPC pareceu muito apropriada.

Para tanto, no primeiro capítulo intitulado Itinerário Delineado para a Pesquisa, fizemos uma abordagem a cerca de alguns elementos que balizaram a escolha, entre eles $\underline{0}$ problema, as questões norteadoras, o objetivo geral da pesquisa. 
No segundo capítulo intitulado: A Construção do Conceito de Célula sob a Perspectiva da Teoria do Perfil Conceitual discutimos a relevância das ideias alternativas na construção do conhecimento, que não deixa de produzir saberes que, como os demais, servem para a compreensão de nosso mundo e de nossa sociedade, e para nela viver com o auxílio de explicações simples e cômodas (LAVILLE, 1999, p.19). Abordamos também os três eixos utilizados que fundamentam a TPC e o papel do professor nessa visão.

No terceiro capítulo, foi feita uma Breve Retrospectiva Histórica sobre o Conceito de Célula Viva, com algumas reflexões a respeito da importância da história da ciência e da microscopia na compreensão desses conceitos e trazendo as perspectivas mais atuais da utilização da célula.

O quarto capítulo trouxe o Percurso Metodológico da Pesquisa: local, delimitação do universo e procedimentos.

No quinto capítulo: Resultado e discussões, apresentamos os resultados, todavia à medida que foram analisados, tivemos a preocupação de estabelecer conexões entre os dados obtidos e o referencial teórico apresentado.

Por fim, as considerações finais, as referências bibliográficas, os apêndices, um texto anexo e a proposta de intervenção. 


\section{ITINERÁRIO DELINEADO PARA A PESQUISA}

Elegemos a pesquisa qualitativa para nortear a investigação, por entender que os dados gerados foram predominantemente descritivos, envolvendo em algum grau valores, fenômenos, crenças e outros; (MINAYO, 1994) utilizamos ainda a análise documental, a observação, diálogos e questionários (pré-testes e pós-testes). O pré-teste foi um conjunto de perguntas feitas aos participantes antes do início da estratégia, com a finalidade de explicitar as ideias dos alunos no que se refere a conceitos básicos celulares, enquanto o pós-teste apontou indicativos sobre quais conceitos foram melhores apreendidos e quais requereram tempo adicional; além dos recursos avaliativos do próprio Colégio Militar

Ressaltamos que as formulações delineadas para compor cada elemento, como o problema, as questões norteadoras e outros, foram se definindo e se constituindo a partir das interações da pesquisadora com o contexto da pesquisa, em um processo que culminou com a elaboração de um produto. O produto proposto constitui um módulo didático de apoio ao professor (a) que trabalha com conceitos celulares.

\subsection{Problema}

O problema de investigação deste estudo foi enunciado da seguinte forma:

Como contribuir para superação das dificuldades dos alunos do 8a ano do EF na apreensão do conceito de célula como fundamento para o estudo do corpo humano de forma integral e não fragmentada?

O estudo do problema permitiu

* identificar algumas dificuldades em se trabalhar com a construção desse conceito, em sala de aula, pelo aluno e pelo professor;

* compreender a importância de estudar um conceito, tão relevante como a célula, "a unidade constituinte dos seres vivos", visando a níveis mais elevados de organização como o próprio organismo. 


\subsection{Questões Norteadoras}

Procuramos elaborar questões claras dentro da temática escolhida e que fossem factíveis com nossa realidade profissional. A sua definição, formulação e análise tiveram origem na própria prática profissional da pesquisadora. As respostas foram ganhando contornos no transcorrer da pesquisa e obviamente poderão ser substituídas, de tempos em tempos, a partir do momento em que novas informações sejam geradas.

- É possível trabalhar o conceito de célula utilizando a TPC, no espaço de sala de aula?

- As ideias alternativas dos alunos são formas qualitativamente diferentes de se interpretar a realidade a sua volta? E essas ideias podem coadunar-se com os conhecimentos científicos?

- Quais as dificuldades apresentadas pelos alunos, quando estudam células no $8^{\circ}$ ano?

- Qual a importância de estudar célula, sob a perspectiva de uma visão mais sistêmica?

\subsection{Objetivo Geral}

Considerando-se a importância que a apreensão do conceito de célula tem no estudo do corpo humano, especificamente aos alunos do $8^{\circ}$ ano; como também no contexto do ensino de ciências, já que esse tema permeia todo ensino fundamental e médio, o objetivo geral do trabalho foi pautado na perspectiva de

- desenvolver uma estratégia de ensino- aprendizagem utilizando os pressupostos presentes na Teoria de Perfil Conceitual para alunos do $8^{\circ}$ ano do Ensino Fundamental sobre célula viva;

- $\quad$ produzir um material didático de apoio para o professor.

Pretendemos assim fornecer elementos que possam propiciar uma reflexão, visando a uma melhoria na prática de docentes. 


\section{A CONSTRUÇÃO do CONCEITO CIENTÍFICO A RESPEITO DE CÉLULA NA PERSPECTIVA DA TEORIA DO PERFIL CONCEITUAL}

A construção do conceito de célula está no centro de um conjunto de conhecimentos científicos importantes dentro da biologia e de grande vulto nos dias atuais, a qual não deixa de ser uma das condições para o exercício da cidadania, a fim de que a pessoa saiba se posicionar frente a processos e inovações que o afetam, como a engenharia genética que utiliza muito dos conceitos celulares.

As Ciências biológicas abrigam questões polêmicas de natureza filosófica, temas que envolvem "vida" e "morte" permeiam o imaginário de muitos. Por isso o conhecimento sobre como a natureza se comporta e a vida se processa contribui para o aluno se posicionar com mais fundamentos. Coutinho (2005) trabalhou com a formação de perfis conceituais sobre vida. Em nossa pesquisa não fizemos perfis de células "vivas", mas usamos alguns dos pressupostos para elaboração da estratégia que auxiliassem alunos na apropriação de saberes, a respeito das microscópicas estruturas de construção dos seres.

No $8^{\circ}$ ano trabalhamos com células eucariontes animais, embora reconheçamos algumas dificuldades dos alunos de olhar a célula para além do ser humano, percebidos tanto em nossa pesquisa, quanto em outros trabalhos na literatura. Procuramos, dentro das possibilidades do tempo letivo, salientar as diferenças entre procarioto e eucarioto (animal e vegetal). Escolhemos também enfatizar os conceitos e funções relativas a célula viva devido as várias conexões existentes nesse tipo de célula e entender que são essas conexões as bases biológicas para diferenciar célula viva de morta, Albert (2011).

Uma breve revisão na literatura deixa evidente como as pesquisas em ensino de ciências têm se ocupado com a análise das concepções alternativas dos alunos, uma vez que é observado que a aprendizagem escolar é influenciada pelo que o aluno já sabe. (MORTIMER, 2000); (OLIVEIRA, 2005); (AUSUBEL, 1980) A década de 1980 pode ser considerada como a época das “concepções alternativas”, apesar de Driver em 1973 já ter chamado a atenção sobre as concepções alternativas dos estudantes, na aprendizagem das ciências.

As concepções alternativas são construções que os estudantes elaboram para dar resposta às necessidades pessoais para interpretar fenômenos naturais, são construídas pelos próprios alunos através de experiências diárias do foro informal Essas resultam da interação com o outro nos cenários socioculturais, são pessoais, bastante estáveis e resistentes à mudança. (MORTIMER, 2006); (DRIVER, 1999) Para o autor "as ideias alternativas das 
crianças e adolescentes teriam sua origem na linguagem e em outras representações simbólicas disponíveis na cultura cotidiana".

A teoria dos perfis conceituais foi inicialmente desenvolvida por Mortimer (1994; 1995; 2000) como uma alternativa à mudança conceitual (POSNER, 1982) que preconiza "mudança conceitual" como o processo pelo qual uma pessoa muda de um conceito a outro, incompatível entre eles. Todavia, Mortimer (2006) ao realizar suas pesquisas acerca da gênese do modelo atomístico para explicar os estados físicos e as transformações da matéria percebeu que não houve uma supressão daquilo que os alunos traziam de sua vivência, "ao contrário, as várias concepções que os estudantes apresentam no início do processo de ensino não eram substituidas pelos conceitos novos, antes passavam a conviver com eles”. (MORTIMER 2006, p. 26)

Após uma fase de instrução, Mortimer (2006 p.42) considera que "o aumento de conhecimento só é efetivo quando o sistema cognitivo do estudante absorve as perturbações atingindo um novo estado de equilíbrio diferente e superior como algo dedutível”

A humanidade precisou das noções científicas de célula para produzir ciência e tecnologia, no entanto no dia a dia não precisamos saber, por exemplo, que muitas vitaminas são precursoras das coenzimas e estão presentes em várias reações químicas na célula; para entender que vitamina é benéfica à saúde, por isso precisamos de uma alimentação balanceada, não obstante, um dos papeis da escola é promover a "enculturação" das noções científicas.

O conceito sobre célula é, sem dúvida, a abordagem inicial e básica para o ensino em biologia. Trata-se de um conceito escolar a respeito da qual o aluno manifesta certo conhecimento trazido de sua vivência, embora nem sempre consiga fazer correlações entre células e o conjunto de músculos, de ossos, de vísceras, de reflexos e de sensações que compõe seu próprio corpo, tratando-os como conceitos desconexos.

Bastos (1992) investigando o conceito de célula de estudantes do $8^{\circ}$ ano verificou que como o objeto célula não possui atributos diretamente perceptíveis, a aprendizagem do conceito de célula se dá principalmente por meio da experiência escolar, no entanto, o ensino de célula apresenta dificuldades típicas de conceitos abstratos, por ser a célula "invisível" e não está no mesmo plano dos fenômenos diretamente observáveis.

Segundo o autor os alunos são influenciados por experiências extraescolares e que de alguma forma consideram as funções celulares numa perspectiva reducionista. Sheldrake (1942, p.54) criticando essa visão reducionista afirma que "quando os biólogos conseguirem reduzir os organismos ao nível molecular, eles passarão o bastão para os químicos e físicos". 
Neste sentido, faz-se necessária uma maior dedicação dos professores na teorização e na prática desse conteúdo, a fim de dar um contorno claro do que seja célula, mas, sem esquecer da visão sistêmica iniciada na minúscula célula chegando até os agrupamentos celulares ordenados que produz o todo que chamamos de organismo, tendo em vista que saber a respeito de células como unidades estruturais isoladamente, pode não ser suficiente para entender todas as suas propriedades ou o contrário.

Caldeira (2009 p. 34), criticando o caráter reducionista da biologia, aborda que embora possa parecer óbvio que o ensino de biologia deva ser centrado no organismo, de forma geral, este perdeu seu papel central nessa Ciência, devido à crescente ênfase aos aspectos moleculares, desatrelado do estudo do próprio corpo. A autora menciona a nova perspectiva da biologia do século XXI, quando afirma que:

\footnotetext{
Avanços recentes na Biologia Molecular e em outros campos que nasceram dela, como a genômica e a proteômica, têm levado a uma compreensão dos sistemas biológicos como redes informacionais complexas, que demandam, para sua compreensão, a adoção de uma perspectiva "sistêmica". (CALDEIRA, 2009, p.34)
}

Refletir que o corpo, feito a partir de trilhões de células, interage com o ambiente, como por exemplo, por meio dos alimentos que chegam até ele, a tecnologia que se conecta a nosso corpo (marca-passos, próteses de membros, próteses dentárias, sensores para recuperar visão ou audição, uma lente de óculos), disparando reações celulares que podem levar a uma descarga de adrenalina ou fazê-lo relaxar, enfim sofrendo a influência do meio. São exemplos de fatores que, por si só, extrapolam o ensino centrado na biologia celular somente e enxergam variáveis que demonstram a interatividade de todo organismo com a tecnologia e o meio externo.

Para Alberts (1997, p. 3), “as células ocupam um lugar intermediário na escala de complexidade biológica". Segundo esse autor, nós a estudamos para sabermos a dinâmica molecular com as quais as células são feitas e, por outro lado, como a cooperação intermolecular origina indivíduos complexos como o ser humano (Figura 1); que por sua vez, é um todo dinâmico que interage com o meio ambiente, tanto no que diz respeito à herança biológica, como as interações de ordem cultural, social e afetiva.

Alberts (2011) considera a célula viva um sistema químico dinâmico que opera distante do equilíbrio e que demanda energia livre e matérias primas adquiridos do ambiente. Murta (2014) chama a atenção para imprevisibilidade de sistemas termodinamicamente abertos como a célula, cuja dinâmica faz com que a célula cresça e se organize construindo estruturas, a partir de informações genéticas codificadas pelas moléculas. 
Segundo Alberts (2011) as moléculas e a energia, livres no ambiente, encontram-se em agitação termodinâmica desordenada. A organização proporcionada pela síntese das moléculas envolvidas confere ligações fortes o bastante para resistir a essa agitação. $\mathrm{O}$ autor afirma que

Na forma de sequência de DNA, por exemplo, as moléculas desses aglomerados em desordem devem ser capturadas, disposta em uma ordem definida por um molde preexistente, e unir-se de maneira estável. As ligações que mantêm as moléculas em seu devido lugar no molde e as une, devem ser fortes o suficiente para resistir a desordem da termodinâmica (ALBERTS, 2011, p. 8).

Para Bastos (1992) o ensino corrente a respeito de conceitos celulares torna-se inócuo quando repousa excessivamente no estudo de detalhes das estruturas e acaba deixando de ressaltar adequadamente aspectos centrais do conteúdo (grandes conceitos e princípios) com ênfase na dinâmica celular.

Figura 1: Interações Moleculares na Formação de um Indivíduo Complexo

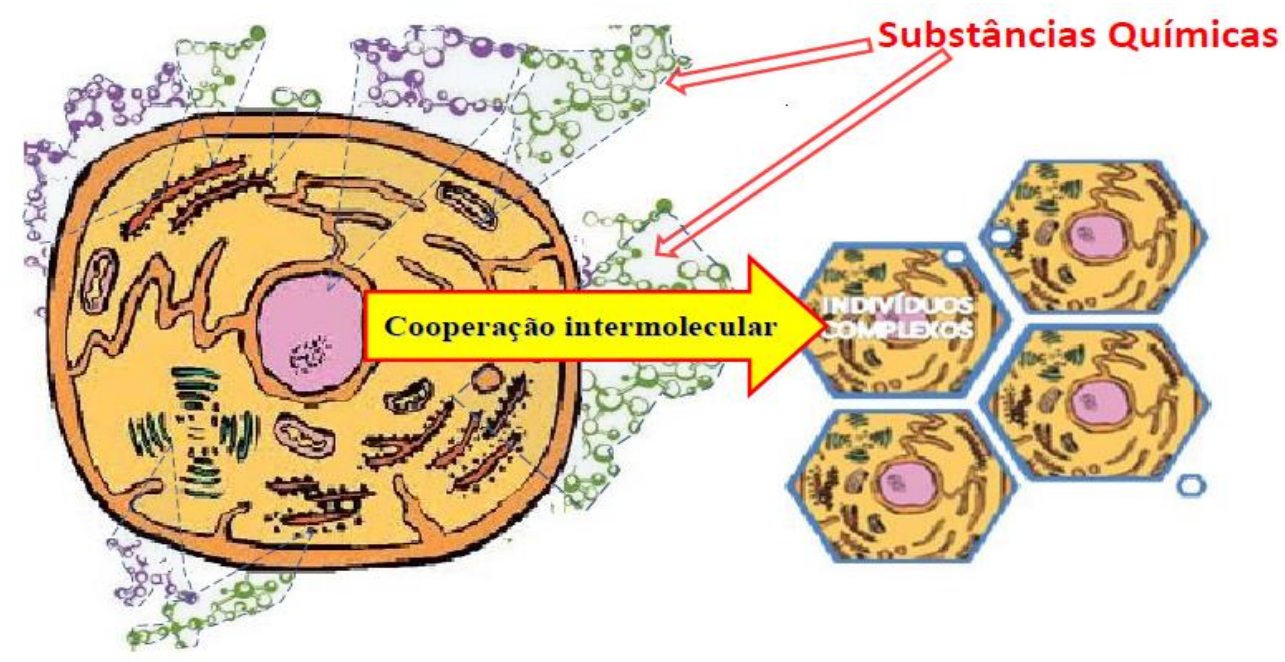

Fonte: Figura adaptada a partir do Google Imagem-2014

O estudo da célula também permite ao aluno fazer associações com outros seres vivos, principalmente considerando aqueles cujo organismo é a própria célula. No caso do ser humano, as células eucariontes realizam tarefas especializadas e estão ligadas por um intricado sistema de comunicações. O sistema de endomembranas é definido com mais precisão como o conjunto de membranas que formam uma única unidade funcional, está distribuída por todo o citoplasma e é formado por vários compartimentos. (Figura 2) Entre as organelas constituintes do Sistema de Endomembranas, destacam-se o retículo endoplasmático, o complexo de Golgi, o lisossomo, o endossomo, a membrana nuclear, os lisossomos e a própria membrana celular. (ALBERTS, 1997) 
Figura 2: Sistema de Endomembranas Celular

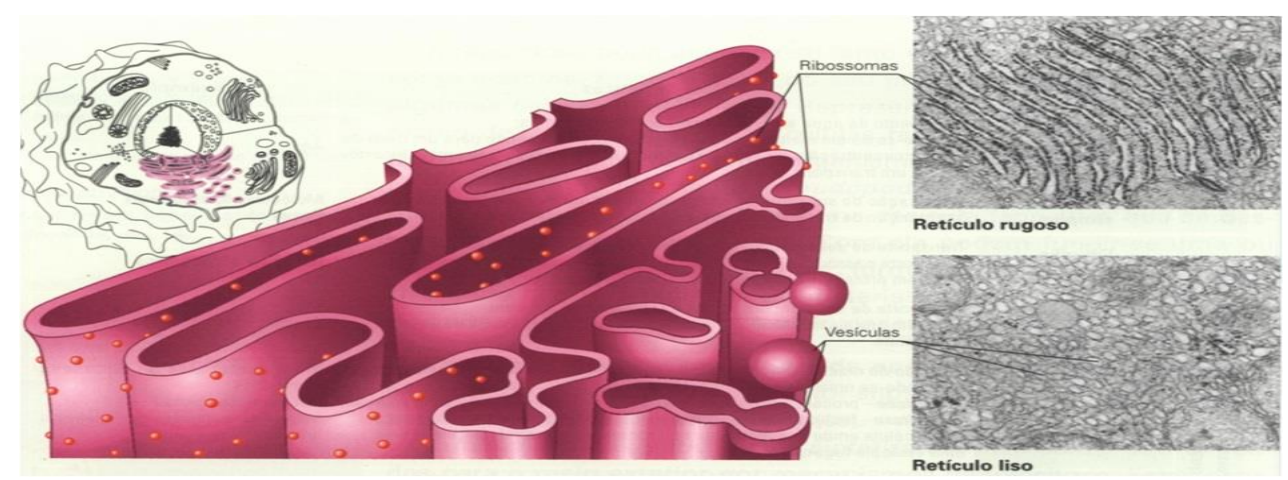

Fonte: Imagem disponível em: </http://biologiacelularufg.blogspot.com.br/2011/06/sistema-de-endomembranas/ >acesso em: 5 set. 2014 .

Existe uma necessidade de compreender bem os conceitos celulares, ao estudar o corpo humano, seus tipos, estruturas e funções; justamente por ser a célula uma unidade fundamental, a peça chave para a formação dos seres vivos. Entender a célula passa ser fundamental para entender o organismo inteiro.

Começando com a origem da primeira célula e como as propriedades de certas moléculas permitiram que a informação hereditária fosse transmitida e se expressasse em seus descendentes e, por conseguinte, no processo evolutivo: pequenas células semelhantes às bactérias até os seres vivos maiores e multicelulares, aos quais se especializaram em funções cooperativas para dar lugar hoje a órgãos intricados como o cérebro humano. (ALBERTS, 1997)

Durante sua pesquisa em Ensino de Biologia, Krasilchik (2004) verificou que a descrição das estruturas formadoras do ser vivo, nos diversos níveis celulares, são apresentadas aos alunos em níveis de organização - células, tecidos, sistemas - que o mecanismo que envolve os diferentes níveis são o metabolismo celular, a ventilação pulmonar e os processos da digestão. Tais conteúdos são demonstrados de forma fragmentada e sem relação com o cotidiano do estudante, logo, não há organização de uma rede de conceitos.

Krasilchik, (2004, p. 31) cita que "são apresentados e cobrados conhecimentos factuais e desconexos". É possível que o aluno não consiga perceber essas interações entre os conteúdos do corpo humano e que com o tempo essa condição contribua para o desinteresse pelos estudos. Em outro trabalho, a autora salienta que a dificuldade pode também estar na incompreensão do vocabulário técnico, existente na área de ciências da natureza, sobretudo nos termos biológicos. ( KRASILCHICK,1996)

Lewontin (2002) também faz referência a essa rede de interações, quando ele afirma que "por meio de uma série de divisões e diferenciações celulares e movimentações de 
tecidos, forma-se um organismo inteiro [...] com um conjunto de órgãos que interagem entre si de maneira complexa" (LEWONTIN, 2002, p. 10). Daí a necessidade de enfatizar a construção do conceito celular robusto, pois recorrentemente ele será necessário na continuação do estudo do corpo humano, sobretudo no $8^{\circ}$ ano do EF.

Uma tentativa de explicar a dificuldade no ensino de conceitos em biologia foi por meio da utilização do modelo de Johnstone (1999), nesse modelo foi proposto um nível sensorial ou perceptivo (nível macroscópico), um nível molecular ou exploratório (nível submicroscópico) e um terceiro nível, o representacional (nível simbólico). No campo macroscópico (corpo humano), o estudante faz muito pouco ou não consegue fazer nenhuma integração com o universo microscópico (células e moléculas) muitas vezes compreendidos como abstratos, devido ao fato de ocorrerem numa realidade não perceptível aos sentidos.

El Hani (2002) chama a atenção para a importância da aprendizagem ordenada e inteligível, caso contrário, ficará limitada ao acúmulo de informações fragmentadas, a semelhança de uma enciclopédia. O autor cita, por exemplo, que é fundamental que os alunos compreendam que em cada uma das etapas nas quais a energia armazenada na forma de ATP é disponibilizada para reações anabólicas das células. Obviamente, o aluno do $8^{\circ}$ ano não aprende vias metabólicas nesse grau de aprofundamento, mas o que se está preconizando é que, a despeito do grau de aprofundamento, o aprendizado terá sua utilidade e seu significado grandemente diminuídos na ausência de uma compreensão de conceitos centrais no pensamento biológico.

O aluno tem seu primeiro contato com o mundo celular já na primeira parte do ensino fundamental, $1^{\circ}$ e $2^{\circ}$ ciclos. Nessa fase ele constrói repertórios de imagens, de fatos e de noções, sendo que o estabelecimento dos conceitos científicos se configura nos ciclos finais. Todavia a dificuldade na sistematização desse conhecimento, por vezes, se arrasta até a universidade.

Quando se trata de biologia, observa-se que no imaginário de muitos, o conteúdo de biologia é difícil devido à enorme quantidade de nomes que precisam "decorar". Muitos não têm consciência de que, a despeito da linguagem técnica, eles trazem muitas ideias compatíveis ou muito próximas daquelas do universo próprio da biologia, a respeito do seu próprio corpo, dos seres vivos, da sexualidade, da saúde e até dos recursos do meio ambiente, só que verbalizada numa outra linguagem; aquela que Mortimer (1999, p. 29) chama de "linguagem da vida cotidiana" e é o modo pelo qual as pessoas percebem e entendem suas realidades. 
Para Montaigne (1972) até a natureza dos gestos corporais traz uma linguagem própria do cotidiano, que pode estar unida à valorização da ciência como conhecimento útil, quando ele afirma que:

Os amorosos brigam, reconciliam-se, imploram, agradecem, marcam encontros com
olhares: o próprio silêncio tem sua linguagem (...). E não nos exprimimos com as
mãos? Pedimos, prometemos, chamamos, despedimo-nos, ameaçamos, suplicamos,
rezamos, negamos, interrogamos, admiramos, recusamos, contamos, confessamos,
manifestamos nosso arrependimento, nossos temores, nossa vergonha, nossas
dúvidas (...). E que mais não externamos, unicamente com as mãos, cuja variedade
de movimentos nada fica a dever às inflexões da voz? (...). Não há gesto ou
movimento em nós que não fale, de uma maneira inteligível que não é ensinada e
que todos entendem. (Montaigne, 1972, p. 215)

A dificuldade é que algumas ideias que os alunos trazem, por vezes, são consideradas, pelo professor como vagas, pouco definidas, resistentes à alteração, incompatíveis e, por isso são deixadas de lado. Vários trabalhos já foram realizados com finalidade de detectar as ideias prévias dos alunos, mas poucos são os estudos que propõem estratégias para o seu aproveitamento. As ideias informais são, na maioria das vezes, perfeitamente adequadas para orientar o trabalho do professor, Driver (1999). A esse respeito Druzian (2004) afirma que:

[...] Um dos grandes desafios a serem tratados nas relações de ensino-aprendizagem é o ensino de conceitos em ciências, tendo em vista os obstáculos de ordem epistemológicos e ontológicos enfrentados tanto por alunos como também por professores, face às concepções ou ideias prévias sobre tais conceitos que os alunos trazem para sala de aula e que tendem a se manter inclusive após sua graduação. (DRUZIAN, 2004, p. 2)

Acreditamos que o professor tem a tarefa principal de mediar o crescimento cognitivo e o amadurecimento dos estudantes, "ajudando-os a conferir sentido pessoal a maneira como as asserções de conhecimento são geradas e validadas” (DRIVER, 1999, p. 33), contribuindo para a construção por parte de cada um de um conhecimento científico. E nessa linha de pensamento a construção não envolve, necessariamente, um afastamento das concepções e ideias que os alunos trazem consigo.

Gowdak e Martins (2009) afirmam que a aprendizagem acontece sempre que ocorre a vivência daquela situação que envolva tais conceitos, possibilitando a construção de generalizações que aos poucos e de forma gradativa, se tornarão mais abrangentes, culminando com a compreensão de conceitos com maior nível de abstração.

Nesse contexto, a maneira como o professor interfere é fundamental. A forma como problematiza, estimula a curiosidade, trabalhada com os recursos disponíveis, os grupos, as diferenças, a diversidade de pensamentos e outros. Faz-se necessário um professor atento a essas questões, tanto no que se refere ao domínio dos conhecimentos especializados daquilo 
que leciona, como a consciência que precisa ter de como os tópicos de um conteúdo estão relacionados entre si, em anos posteriores e em graus de profundidade, com aquilo que os estudantes já sabem. Segundo Ball (2008, p. 34) 'Ensinar exige conhecimento além daquele a ser ensinado aos alunos. Exige-se uma compreensão diferente, por exemplo, mais do que perceber e identificar um erro, o professor deverá saber a natureza do erro".

Como mediador, o professor também deve conseguir estabelecer conexões entre o que os estudantes já sabem e o novo conhecimento científico que pretende construir com eles, levando em consideração seus conhecimentos espontâneos. Para Hentz (1998)

$\mathrm{Na}$ educação escolar, o professor passa a ter a função de mediador entre o conhecimento historicamente acumulado e o aluno. Ser mediador, no entanto, implica também ter-se apropriado desse conhecimento. (HENTZ, 1998, p. 15).

As pesquisas de Mortimer (2006) têm mostrado que muitas vezes, conceitos espontâneos coexistem com conceitos científicos aprendidos na escola. Desde que o professor interfira adequadamente, o aluno pode ganhar consciência da coexistência de diferentes sistemas explicativos para o mesmo conjunto de fatos e de fenômenos. Isso ocorre porque a aprendizagem tem muito mais sentido à medida que o novo conteúdo é incorporado às estruturas de conhecimento do aluno e adquire sentido para ele, a partir da relação com seu conhecimento prévio, estando apto a reconhecer e a aplicar diferentes domínios de ideias em diferentes situações.

Daí a importância de o professor usar uma estratégia que acesse as ideias dos estudantes e as torne conhecida para o estudante. Mortimer (2006, p.57) afirma que "o processo de explicitação de ideias em sala de aula, mais do que possibilitar um aprendizado científico dá aos estudantes uma arma para enfrentar a ciência da vida: a crítica". Ganhar consciência da existência de diferentes fontes de explicação para as coisas da natureza e do mundo é tão importante quanto aprender conceitos científicos novos.

Acompanhando o dia a dia letivo da formação de conceitos novos, seja de célula viva seja de demais conceitos do corpo humano, percebe-se a necessidade de dar "vida" a esses conceitos, proporcionando-lhes uma visão mais ampla e promovendo condições de que o aluno, em algum momento, as correlacione ao seu próprio cotidiano, ao mesmo tempo em que os nossos próprios conceitos vão também ganhando formas diferentes, olhares e quem sabe, novas adequações. Se pudéssemos observar o processo interativo entre professor e aluno, poderíamos ter uma noção do complexo "vai-e-vem" de imaginação, de interpretação, de reformulação, de reinterpretação que permeiam cada movimento de uma pessoa e de cada 
pessoa e o "conjunto de anônimos", que forma a base da educação moderna. (MARTINS, 1998)

Muitas vezes percebia que após as aulas teóricas ou práticas sobre células, os alunos respondiam imediatamente aos questionamentos. No entanto, algum tempo depois, acerca do mesmo conteúdo ou em conteúdos correlatos, apareciam erros conceituais consideráveis. Por exemplo, quando falava a respeito do transporte e distribuição de gases pelo corpo, abordado no conteúdo do sistema circulatório, eles não associavam isso às hemácias, ou ainda, quando falava da necessidade das células produzirem energia para realizar suas atividades, questões diretamente ligadas ao estudo do sistema digestório e respiratório, os alunos apresentavam ideias difusas do conceito de célula, muitas vezes invertendo conceitos típicos de biomoléculas (DNA, proteínas, cromossomos etc.) ou órgãos, com aqueles de células propriamente ditas ou simplesmente não correlacionando respiração celular a nenhum sistema.

Particularmente, atribuía esse fato à falta de interesse e de motivação na aprendizagem, ou ainda, à ausência de "pré-requisitos". Mortimer (2006, p. 51) faz referência as "lacunas da aprendizagem" quando diz que: "a falta de informações para interpretar os resultados de um experimento pode ser um obstáculo maior que o conflito entre as ideias do estudante e os resultados apresentados".

Só com o passar dos anos, percebi que havia algo mais nas respostas dos alunos que fugia à simples explicação de "falta de interesse". Durante muito tempo, em nenhum momento, minha prática pedagógica considerou os conhecimentos, as impressões e as concepções que os alunos traziam com eles.

O aluno tem claro que 'respiramos' ritmicamente, pois desse movimento depende sua vida, mas em geral não associa que toda a indumentária anatômica de captação do ar que ele inspira (ventilação pulmonar) não é a atividade fisiológica fim e sim o meio para que o oxigênio chegue às células e realize a respiração celular. São vários conceitos que se conectam, mas o aluno nem sempre consegue generalizar as explicações para outros fenômenos. Segundo Bastos (1992)

\footnotetext{
Para que o aluno não desenvolva visões parciais ou distorcidas do papel da célula no organismo, é necessário que o professor identifique e discuta processos fisiológicos para cuja realização a atividade celular isolada é insuficiente, isto é, processos que só se realizam mediante a cooperação de diferentes células. (BASTOS, 1992, p.67).
}

Exemplificando a fala do autor, poderíamos dizer que do ponto de vista bioquímico, respiração celular é o processo de conversão das ligações químicas de moléculas ricas em 
energia que possa ser usada nos processos vitais, mas, que cada célula do sistema respiratório, tem um papel específico nessa engrenagem e que corroboram para o bem de todo processo, seja por meio de células endoteliais dos capilares alveolares, seja por pneumatócitos ou demais células do sistema respiratório.

Não obstante, é preciso considerar que o conhecimento formal, como o exemplificado anteriormente, pelo qual dialogamos com o aluno, foi construído em algum momento histórico, sendo resultado da construção de uma comunidade científica em relação à maneira de ver aquele determinado fenômeno, Driver (1999); e como tal, para cada conhecimento tornado público, existe uma história de como ele foi construído e interpretado. Para Machado (2002):

(...) o ser humano é o resultado do meio cultural em que foi socializado. Ele é
herdeiro de um longo processo acumulativo, que reflete o conhecimento e a
experiência adquirida pelas numerosas gerações que o antecedem. A manipulação
adequada e criativa desse patrimônio cultural permite as inovações e as invençôes.
Estas não são, pois, o produto de uma ação isolada, mas o resultado do esforço de
toda uma comunidade. (MACHADO, 2002, p.24).

Segundo Fourez (1995, p. 46) quando se quer definir algo, o ser humano utiliza sempre um esquema teórico admitido. Para o autor uma definição "é a releitura de um certo número de elementos do mundo, por meio de uma teoria[...]assim, a definição de uma célula em biologia, não é um ponto de partida, mas resultado de um processo interpretativo teórico". Para o autor o conhecimento científico é socialmente reconhecido e historicamente condicionado, ambos, extremamente eficazes para resolver inter-relações com o mundo. Os conceitos científicos não são dados, e sim construídos.

O DECEx, reconhecendo especialmente, a mediação do professor, a historicidade, os aspectos filosóficos implícitos e outras perspectivas que propiciem condições objetivas de apropriação do conhecimento, alterou os três pilares do ensino do SCMB: currículo, avaliação e didática, preconizando que as aulas devam ser balizadas por três temáticas: construtivismo, mediação e letramento.

O Construtivismo parte do pressuposto de que o saber não é algo que está concluído, terminado, e sim um processo em incessante construção e criação. Mortimer (1996) afirma que existem variadas abordagens e visões a respeito do construtivismo, mas há pelo menos duas características compartilhadas entre essas visões: a primeira diz respeito ao envolvimento ativo do aprendiz no processo de construção do saber e a segunda é a que leva em conta as teorias informais que as pessoas carregam sobre os fenômenos.

Mortimer (1999) aponta algumas dificuldades dos professores em sala de aula quando utilizam uma abordagem construtivista e que pode ser desfavorável, por exemplo, no 
momento que tentam simplesmente ampliar os conhecimentos que os estudantes já possuem dos fenômenos ou organizar o pensamento de senso-comum dos alunos e também, nos casos em que as ideias alternativas são claramente antagônicas ou conflitantes com os conceitos científicos e o professor tem dificuldade de lidar com essa situação. Segundo o autor "gastase muito tempo com poucos conceitos, e muitas vezes esse processo não resulta na construção de conceitos científicos".

O professor ao fazer a mediação do conhecimento precisa ter claro que conceitos cotidianos e científicos envolvem experiências e atitudes diferentes e se desenvolvem por caminhos diferentes, mas não necessariamente opostos, "a ausência de um sistema é a diferença psicológica principal que distingue os conceitos espontâneos dos conceitos científicos" (VYGOTSKY, 1999, p. 99). Ou seja, os sujeitos possuem dois sistemas de formação conceitual: um baseado em categorias difusas ou probabilísticas, relacionadas a contextos particulares, e o outro em conceitos clássicos, ou logicamente definidos. Um conceito espontâneo não possui uma organização consistente e sistemática, enquanto o conceito científico é sempre mediado por outros conceitos.

Para Driver (1999), a mediação entre esses sistemas na atividade elaborada em sala de aula requer do professor que ele consiga desafiar as concepções prévias do aluno, de modo a encoraja-lo e não substituí-lo. Mostrando ao aluno que as concepções prévias são as primeiras compreensões do mundo, herança de um grupo social e de experiências pessoais, mas apresentando-lhe uma nova abordagem cientifico-tecnológico a partir do conhecimento historicamente acumulado pela humanidade.

Para a autora, existe uma tradição dentro do construtivismo que descreve o "processo de construção do conhecimento como consequência da aculturação do aprendiz nos discursos científicos". Entende-se, assim, que o conhecimento é erguido por meio da ação de um aprendizado que é produto da conexão do ser com o contexto material e social em que vive, com os símbolos produzidos pelo indivíduo e com o universo das interações vivenciadas na sociedade. Nesse particular pode-se aferir que a biologia é uma ciência que apresenta intensas relações com as atividades desenvolvidas pelo ser humano, porém, apresenta também uma linguagem própria, que necessita maior atenção por parte de educandos e educadores no momento de inseri-lo no discurso científico.

Driver (1999) afirma que os objetos da ciência não são os fenômenos da natureza, mas as construções desenvolvidas pela comunidade científica. Nas DCN lemos que "educação consiste no processo de socialização da cultura da vida, no qual se constroem, se mantêm e se transformam saberes, conhecimentos e valores" (BRASIL, 2013, p. 18) e, segundo o mesmo 
documento, as fontes em que residem os conhecimentos escolares são as práticas socialmente construídas, que podem ser consideradas:

a) às instituições produtoras do conhecimento científico (universidades e centros de pesquisa);

b) ao mundo do trabalho;

c) aos desenvolvimentos tecnológicos;

d) às atividades desportivas e corporais;

e) à produção artística;

f) ao campo da saúde;

g) às formas diversas de exercício da cidadania;

h) aos movimentos sociais

Esse legado de conhecimento, construído, aceito e "comunicado através da cultura" como exemplifica Driver (1999, p. 9) é mediado pelo professor, o qual, a partir desses pressupostos é capaz de proporcionar um ambiente mais favorável ao aluno, não apenas para apreensão dos conhecimentos/entendimentos já estabelecidos pela humanidade, mas meios para que também os associe a sua própria realidade, a fim de que possa construir novos entendimentos e também aprofundar os conhecimentos existentes. Durante o processo de aprendizagem, tanto o aluno quanto o professor se dão conta de que as descobertas não são verdades inquestionáveis, mas sim conhecimentos provisórios sujeitos às contraposições e às validações por parte deles mesmos enquanto sociedade.

Sendo a célula considerada pela comunidade científica a unidade morfofisiológica da vida, deve-se despertar, no professor, apreciável empenho para mediar o entendimento de conceitos chave a respeito da sua composição, organização e comportamento. A apropriação de seus conceitos e procedimentos pode contribuir para a ampliação das explicações acerca dos fenômenos da natureza, para a compreensão e valoração dos modos de intervir na natureza e de utilizar seus recursos, contribui ainda para o aluno se posicionar com fundamentos acerca de questões polêmicas como a manipulação gênica. Todavia, a consolidação de um conceito não é algo simples. Segundo Vygotsky (2001):

Um conceito é mais do que a soma de certos vínculos associativos formados pela memória, é mais do que um simples hábito mental; é um ato real e complexo de pensamento que não pode ser aprendido por meio de simples memorização [...] (VYGOTSKY, 2001, p. 246). 
Vygotsky destaca que a complexidade a apreensão de conceitos envolve outras variáveis e não somente a capacidade biológica de captar, de analisar e de transformar estímulos em conhecimento que ocorre nas células nervosas, extrapolando, ou seja, envolve também a interação da coletividade (incluindo o professor), que por sua vez influencia a cognição individual do aluno e a sua própria cognição.

Considerando que nossa experiência social é diferente e multifacetada devida à cultura, à história, ao ambiente e a diversidade de significados estabilizados em diferentes linguagens sociais e com diferentes pesos, em diferentes épocas, podemos esperar, portanto, resultados diferentes. (MORTIMER; SCOTT; EL-HANI, 2011), por exemplo, se considerarmos que ao começarmos o magistério interagimos com um estudante de 13 anos de idade, (média de idade para alunos do $8^{-}$ano) após trinta anos seguidos continuaremos interagindo com um estudante de 13 anos, só que agora com três décadas de profundas transformações pessoais e coletivas impactando diretamente essa interação.

É possível que diante dessas questões, o professor se sinta intimidado a não despertar para novas abordagens de mediação, seja por medo, seja por falta de conhecimento, seja por acomodação. Mesmo o professor, que a despeito de todo empenho em seu planejamento de aula, do domínio do conhecimento científico da matéria que leciona, dos recursos adequados, entre outros, não é garantia plena do que e do quanto os alunos aprenderão. Conseguir identificar diferenças e conhecer o processo cultural nos quais os jovens se envolvem podem ser itens importantes, já que a relação entre professor e aluno inevitavelmente compreende um choque de gerações, valores e culturas.

É preciso que o professor perceba que outras variáveis interferem no processo de desenvolvimento do educando e que compõem as noções que eles trazem para sala de aula. Krasilchik (2004) cita alguns: sociais, econômicos, culturais, ambientais e o próprio senso comum, os quais conduzem, facilitam ou dificultam o desenvolvimento do aprendiz.

São inúmeros os exemplos presentes na vida social, construídos pelo "ouvi dizer", que formam uma visão de mundo fragmentada e assistemática. Mesmo assim, é uma forma usada pelo homem para tentar resolver seus problemas da vida cotidiana. Um estudante pode saber, por exemplo, que chá de boldo é usado para curar um mal-estar do fígado, sem conhecer os princípios ativos que regem a ação terapêutica nos hepatócitos - células do fígado.

É possível ainda que os alunos resolvam corretamente os problemas relacionados a conceitos de célula, obtendo até mesmo uma boa nota na avaliação. Porém, não quer dizer que isso represente uma efetiva compreensão do conteúdo de modo a internalizá-lo, atribuindo-lhe 
significados pois "a maior parte do saber científico, ensinado durante a escolaridade, é esquecida após alguns anos, algumas semanas até”... (GIORDAN; VECCHI, 1996, p. 9)

No entanto, investigações que Vygotsky (2000) e seus colaboradores conduziram com crianças em idade escolar mostraram que quando o currículo é apropriado, o desenvolvimento de conceitos espontâneos pode ser superado por conceitos científicos. Entenda-se "superação" como a capacidade de acessar e operar esse novo conceito. Ele admite que o problema se deva ao fato de o estudante ter dificuldade de associar situações do seu cotidiano ao novo conceito apresentado pela inconsciência de seu próprio arcabouço conceitual.

Nas DCN (BRASIL 2013, p. 20) essa abordagem foi contemplada quando se afirma que o arcabouço teórico dos currículos deve ser orientado pelo "pluralismo de ideias e de concepções" assim como pela "valorização da experiência extraescolar, e a vinculação entre a educação escolar, o trabalho e as práticas sociais”. Portanto, é salutar que o professor como mediador do processo busque o conhecimento prévio do aluno, ao introduzir um novo assunto, pois o cérebro responde positivamente a essas situações, ajudando a fixar não somente fatos, mas também conceitos e procedimentos.

É oportuno refletir a necessidade de buscar um equilíbrio, como professores de ciências, dos conceitos espontâneos e dos conceitos científicos, pois eles não estão em conflito, como em alguns momentos somos tentados a pensar, visto que se articulam dialeticamente e fazem parte do mesmo processo.

Teixeira (2006) faz menção à mesma ideia, quando afirma que é "preciso considerar que, o aprendizado de um novo conhecimento científico não requer o abandono de outros conhecimentos, quer seja de outra teoria científica ou de saberes de senso comum na cultura do indivíduo", devemos então equacionar esses conhecimentos a favor do aprendiz. Não ocorrem rupturas, o que acontece é que o indivíduo é apresentado a uma nova linguagem, novos parâmetros, novas formas de ver o mesmo fenômeno.

Ora, como então podemos entender os conhecimentos prévios dos alunos se em algum momento não explicitarmos isso? É fundamental trazermos essas discussões para a sala de aula (MORTIMER 2011, p. 171). Como podemos planejar uma aula sem considerar a possibilidade de o aluno carregar consigo outro modelo explicativo, resultante de sua vivência? Um adolescente do $8^{\circ}$ ano "apaixonado" pode explicar, no cotidiano, as questões amorosas simbolizadas como corações flutuantes, que causam frio na barriga, poético, romântico e na aula dizer que é o resultado de mecanismos fisiológicos, que envolvem hormônios e receptores cerebrais. 
A TPC foi fundamentada a partir de três eixos (Figura 3), que em linhas gerais podem ser assim descritos: Desenvolvimento da Cognição Individual; História e Filosofia da Ciência; Desenvolvimento social de ideias em sala de aula. Esse tipo de estudo já foi realizado em relação aos conceitos de reações químicas, átomo e de estados físicos dos materiais, calor, transformação e outros, ou seja, para alunos do EM e EF. Os três eixos, são dinâmicos e se articulam entre si. Passaremos a alinhavar algumas reflexões acerca deles.

FIGURA 3: OS TRÊS EIXOS QUE FUNDAMENTAM A TPC

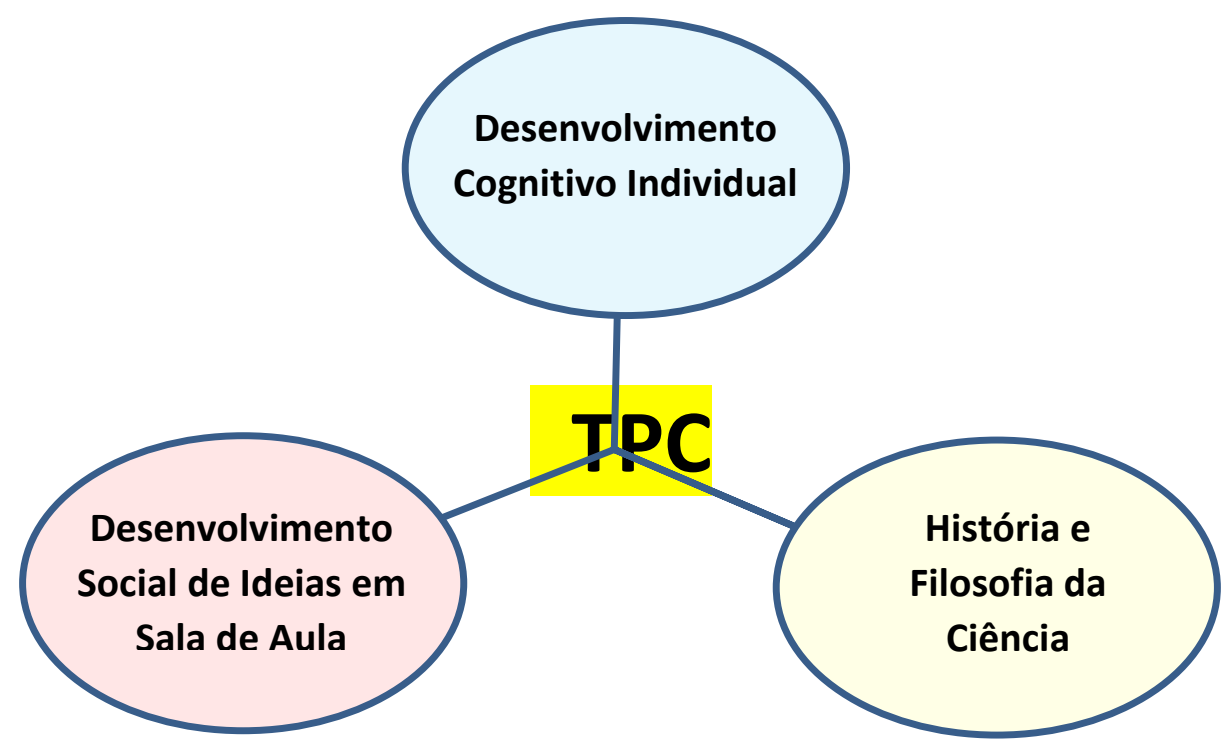

Fonte: Esquema da autora, 2014

\subsection{Desenvolvimento da Cognição Individual}

Mortimer (2006), ao descrever o eixo da cognição individual, utilizou como suporte teórico para proposta de ensino a teoria piagetiana de equilibração, as investigações sobre generalização e a revisão crítica das teorias sobre mudança conceitual, na qual faz críticas a alguns aspectos psicológicos e filosóficos dessas abordagens. Outro suporte teórico utilizado nesse eixo são as concepções alternativas que os alunos trazem consigo e a gênese dos conceitos.

De acordo com o modelo de "mudança conceitual" (POSNER. 1982) de ensino/aprendizagem, há a necessidade por parte dos estudantes de uma análise de seus próprios conceitos, a fim de que possam ser questionados e substituídos por novos. Seria esperado que o estudante abandonasse suas concepções prévias/alternativas, ao perceber suas limitações e incompatibilidade com o conceito científico, e substituísse pelo novo conhecimento construído. A base do referido modelo, portanto, é compreender como as 
concepções científicas mudam sob o impacto das novas ideias e informações. Porém, resultados dos estudos sobre mudança conceitual mostraram que estudantes não abandonam facilmente suas concepções prévias, mas elas persistem mesmo após os anos de escolaridade. (MORTIMER, 1996); (POZO, CRESPO, 1998); (SILVA; AMARAL, 2006)

O eixo de "Desenvolvimento da Cognição Individual" da TPC, em linhas gerais, trabalha com essa nova abordagem e propõe a convivência entre as concepções prévias dos alunos e as concepções científicas. Mortimer (2006) em sua pesquisa deixa claro que cada indivíduo, embora pertencente a uma mesma cultura, em decorrência das experiências distintas variadas, possui o seu próprio perfil correspondente a sua forma de entender a realidade, e que por isso qualquer pessoa pode possuir mais de uma forma de compreensão da realidade, o que lhe possibilita dialogar com várias referências, para a aquisição de um novo conceito.

O professor para trabalhar com essa pluralidade de experiências precisa ter claro que há dificuldades na aprendizagem não somente ligados aos conhecimentos prévios "inconsistentes cientificamente" dos alunos, mas que derivam, por exemplo, de dificuldades de manuseio da linguagem, ou mesmo à ignorância sobre determinado assunto, daí a importância de um suporte teórico que contribua nesta avaliação cuidadosa acerca do que está ensinando. $\mathrm{O}$ acesso as ideias do aluno é um primeiro passo, mas só terá validade como fonte de enriquecimento e possibilidade de avanço, se for observável pelo aluno.

O papel do professor nesse cenário é muito importante, não só em termos de organização do ambiente e disponibilização de materiais, mas principalmente no sentido de instigar, desafiar, informar e orientar os alunos. Além disso, ter claros os conteúdos que se deseja desenvolver (aqui entendidos os conteúdos não só como conceitos, mas também como procedimentos e atitudes).

Krasilchik citando (GUNSTONE, 1988 p. 31) traz à discussão outro argumento, quando afirma que todo aluno tem um acervo de conhecimento e que "trazem para a sala de aula ideias próprias, mas inadequadas, que influem fundamentalmente e criam dificuldades não só no aprendizado do conteúdo, mas também no de habilidades como a de observação, tão essencial em biologia"; ou seja, os alunos têm noções sobre seu corpo, só que carregada de uma lógica interna, própria dele. Todavia, é possível que se as ideias do aluno forem provocadas para explicar um determinado fenômeno, ele perceba os limites dessa noção e a 
necessidade de novas informações, sem a necessidade de abandonar as suas concepções prévias Mortimer (2006). Para Martins (1998)

O senso comum é comum não porque seja banal ou mero e exterior conhecimento. Mas porque é conhecimento compartilhado entre os sujeitos da relação sócia. Nela o significado a precede, pois é condição de seu estabelecimento e ocorrência. Sem significado compartilhado não há interação. Além disso, não há possibilidade de que os participantes da interação se imponham significados, já que o significado é reciprocamente experimentado pelos sujeitos. (MARTINS, 1998, pág. 3)

Segundo Coll (2006), quando o aluno se depara com o conteúdo a ser aprendido, sempre se apoia em conceitos, concepções, representações e conhecimentos já adquiridos de suas experiências anteriores, para então, poder organizar e estabelecer relações entre elas. Assim, uma aprendizagem com mais sentido para o aluno surge quando ele consegue estabelecer relações entre o que já conhece e o novo conteúdo que lhe é apresentado.

Vygotsky (2001) admite que a construção do conhecimento não exija uma ruptura com o senso comum, ele considera que é mesmo que os dois conceitos caminhem em direções opostas, é possível que aja um diálogo . Ele afirma:

[...] os conceitos quotidianos abrem caminho para os conceitos científicos e o seu desenvolvimento descendente... os conceitos científicos, por seu turno, fornecem estruturas para o desenvolvimento ascendente dos conceitos espontâneos da criança rumo à consciência e à utilização deliberada. (VYGOTSKY, 2001, p. 251-252).

Sforni e Galuch (2005) citam a importância da escola em tomar como ponto de partida os conhecimentos prévios, "envolvendo-os em problematizações cujas resoluções exijam novos e, por vezes, conhecimentos mais complexos do que os iniciais". Dessa forma a articulação entre o conteúdo e o cotidiano do aluno se faz de maneira mais efetiva, além de possibilitar um planejamento mais eficiente pelo professor.

O aluno constrói sua aprendizagem, seus conceitos, enfim seu arcabouço de conhecimentos, usando-os em diferentes circunstâncias até que se tornem propriedade sua, e podendo usá-los com autonomia. É papel da escola elaborar atividades, que demandem tempo ou não, que auxiliem na viabilização desse processo. Rosa (1997, p.48, apud SFORNI e GALUCH, 2005, p. 10) afirma que:

A escola por desconhecer os conhecimentos prévios dos estudantes, simplesmente justapõe novas informações às preexistentes sem chegar a transformá-las. O uso da nomenclatura técnica, por exemplo, pode encobrir campos conceituais desconhecidos de nossos alunos, impedindo a integração das novas explicações às estruturas explicativas pré-existentes (ROSA 1997, p.48, apud SFORNI e GALUCH, 2005, p. 10). 
Vygotsky (1991) faz referência à importância do professor nesse contexto, quando ele afirma que a experiência prática mostra que o ensino direto de conceitos é impossível e infrutífero.

Um professor que tenta fazer isso geralmente não obtém qualquer resultado, exceto o verbalismo vazio, uma repetição de palavras pela criança, semelhante à de um papagaio, que simula um conhecimento dos conceitos correspondentes, mas que na realidade oculta um vácuo. (VYGOTSKY, 1991, p. 72).

Portanto, embora na sala de aula, existam posições socialmente e tradicionalmente estabelecidas nas atividades singulares, onde a perspectiva é que ao professor caiba à tarefa de "transmitir conceitos novos" há sempre possibilidades de rupturas e produção de novos sentidos. O professor pode recorrer a experiências vivenciadas pelos alunos, com o propósito discursivo de favorecer a aprendizagem. As ideias explicativas dos alunos podem servir de "andaimes indispensáveis à construção de conhecimentos novos, com os quais os alunos ainda não estão familiarizados".

Considera-se que as concepções do mundo que o aluno tem são fundamentais na explicação do modelo que está sendo criado ou experimentado, pois ele precisa comparar o modelo ao mundo real para se certificar que suas concepções espontâneas a respeito do assunto que está sendo modelado têm fundamento ou não. $\mathrm{O}$ grande desafio e proporcionar aos alunos atividades que o aproximem do fazer ciências, enfrentando problemas reais e procurar soluções para eles, ou seja, partindo de seus conhecimentos prévios sejam capazes de utilizar conhecimentos científicos para explicar fatos que acontecem no seu cotidiano, incluindo a dinâmica do seu corpo.

No âmbito da sala de aula, percebemos que as fontes das relações interpessoais se referem a professores e alunos e, também, entre alunos e alunos, que muitas vezes é vista como reflexo da desordem na sala de aula. Todavia, como já abordado anteriormente, o aluno traz consigo as crenças, os valores, os seus modelos mentais acerca da sua realidade e constrói o seu repertório de conhecimentos. Por outro lado, sabemos que tais atividades construídas frente aos conteúdos escolares aparecem inseridas na trama das atividades sociais, portanto, coletivas, logicamente superando o aspecto individual, em outras palavras, o aluno constrói o seu conhecimento, porém nunca o faz sozinho. 


\subsection{História e Filosofia da Ciência}

A TPC considera relevante o papel da história da ciência na construção da proposta de ensino de um tema específico e igualmente importante o papel da filosofia. Considerando que conceitos elaborados pela ciência, sofrem explicita influências históricas, sociais, políticas e econômicas, pode-se aferir que a utilização da história da ciência tenha potencial de direcionar olhares para uma ressignificação dos conteúdos abordados nas aulas de biologia.

A compreensão das contribuições da filosofia e história da ciência, para minha prática pedagógica, só foi possível ao perceber a forma como eu mesma enxergava a ciência, ou seja, como um conjunto acabado e estático de verdades definitivas, fragmentada em pacotes fechados à argumentação e à dúvida. Foi preciso haver um reposicionamento de meus próprios paradigmas, para entender que o conhecimento científico não se faz de forma inerte, uma vez que sua evolução está relacionada tanto com as mudanças históricas quanto sociais.

Muitos pesquisadores em educação têm ressaltado que a utilização da história da ciência no ensino é meio eficaz ou mesmo fator imprescindível da melhoria do ensino de ciências [(GAGLIARDI, 1988); (MATTHEWS, 1990)], entre outros. Segundo Krasilchik (2004)

\footnotetext{
A inclusão da história e filosofia das ciências no currículo de biologia tem sido defendida, com argumentos de ordem pedagógica, por educadores e cientistas ao longo das transformações por que vem passando o currículo daquela disciplina (biologia) nos vários níveis de escolaridade. (KRASILCHIK ,2004, p. 33)
}

Sua importância epistemológica está calcada na construção de propostas para temas específicos. Os alunos poderão desenvolver a compreensão do modo como a ciência realmente se desenvolve, do caminho que conduziu à compreensão atual de tais ideias, dos papéis desempenhados por diferentes investigadores e da interação com a teoria ao longo do tempo. Segundo Fourez (1995):

Para ser um individuo autônomo e um cidadão participativo em uma sociedade altamente tecnicista deve-se ser científica e tecnologicamente alfabetizado... sem certas representações que permitam compreender o que está em jogo no discurso dos especialistas, as pessoas ariscam-se a se verem tão indefesas quantos os analfabetos em uma sociedade onde reina a escrita (FOUREZ, 1995, p. 222)

O conhecimento da história e filosofia pode servir também como um importante instrumento de comprometimento, ao trazer a luz os efeitos da ciência e da tecnologia na vida moderna de caráter ético, social ou ambiental e das vantagens ou não advindas dele, e uma análise histórica permitiria aos alunos compreenderem seu significado na linha do tempo e a 
visão de mundo implícita, de tal modo que, a introdução da história e filosofia da ciência influenciam a cidadania e a tomada de decisões e em última análise ao suporte da própria ciência (KRASILCHIK, 2004).

Muitos dos documentos oficiais, como as DCN (BRASIL, 2013), produzidos nas últimas décadas enfatizam a importância da Filosofia e da História da Ciência para a construção do conhecimento científico. As DCN (BRASIL, 2013 p.161), ao se referirem à ciência afirma que se trata de um: "conjunto de conhecimentos sistematizados, produzidos socialmente ao longo da história, na busca da compreensão e transformação da natureza e da sociedade". Em outras palavras, ao longo de sua história os seres humanos têm construído modelos da realidade como maneira de possibilitar a sua interação com essa realidade. A ciência é resulta da adoção de um modelo explicativo da realidade.

Um olhar mais aprofundado a respeito da importância da compreensão da historicidade do conhecimento científico, pode nos ajudar a ter uma postura menos preconceituosa, frente a tantas outras formas de conhecimento construídas a partir das experiências dos humanos e sua proximidade com a natureza. Essa percepção deve-se até mesmo ao caráter circunstancial e até provisória do conhecimento. Segundo Almeida (2006)

Todas as épocas têm seus sábios, mas nem todas as pessoas que produziram conhecimentos relevantes nas diversas culturas tiveram seus nomes divulgados, conhecidos. Na época de Isaac Newton, Galileu Galilei ou Nicolau Copérnico, certamente outros saberes estavam sendo construídos sobre os mesmos temas por eles estudados, mesmo que não saibamos onde e quem se dedicava a responder as mesmas perguntas formuladas por esses grandes homens da ciência. (ALMEIDA, 2006, p. 107).

Portanto, considerando que o conhecimento científico é atemporal e diretamente relacionado com o pensamento vigente em diferentes períodos históricos, é salutar que o professor compreenda como se processou a relação entre o sujeito e o objeto do conhecimento, isso só será possível se compreender como tais conceitos evoluíram durante os séculos até os dias atuais. Libâneo (2013) cita que o ensino tem como tarefa principal assegurar a difusão dos conhecimentos sistematizados e legados pela humanidade ao longo da história e, como tal, sofre influências diretas do contexto histórico.

Ao estudar a história da ciência, percebem-se como em cada época as abordagens se dividiram, foram contraditórias, sofreram questionamentos e que de uma forma ou de outra, orientou a evolução e construção do conhecimento, visto que a evolução do pensamento científico está intimamente ligada à evolução das ideias filosóficas e à própria cultura na qual ele foi gerado. (GIORDAN; VECCHI, 1996). Concordamos com El Hani (2009) quando ele afirma que: "não se trata somente de incluir uma abordagem dos processos de construção do 
conhecimento científico no Ensino de Ciências, mas de considerá-los no contexto histórico, filosófico e cultural em que a prática científica tem lugar (...)” (EL-HANI, 2009, p.4-5)

As pesquisas com células-tronco embrionárias, por exemplo, por vezes, esbarraram em questões éticas e religiosas. No Brasil o artigo $5^{\circ}$ da Lei de Biossegurança (Lei $\mathrm{n}^{\circ} 11.105$, de 24 de março de 2005) liberou, com restrições, a pesquisa com células-tronco de embriões obtidos por fertilização in vitro e congelados há mais de três anos, mas, em 29 de maio de 2008, o Superior Tribunal Federal, após vários embates, aprovou as pesquisas com célulastronco embrionárias, afirmando que "O Supremo Tribunal Federal decidiu que as pesquisas com células-tronco embrionárias não violam o direito à vida, tampouco a dignidade da pessoa humana", transformando o Brasil no primeiro país da América Latina e o $26^{\circ}$ no mundo a permitir esse tipo de pesquisa. Para Goulart (2005)

\begin{abstract}
A ciência não é apenas uma coleção de leis, um catálogo de fatos não relacionados entre si. É uma criação da mente humana, com seus conceitos e ideias livremente inventados. As teorias... tentam fomentar um quadro da realidade e estabelecer sua conexão com o amplo mundo das impressões sensoriais. Assim a única justificativa para as nossas estruturas mentais é se de que maneira as nossas teorias formam tais elos. (EINSTEIN e INFELD, 1976, p. 235, apud GOULART, 2005, p. 3-4).
\end{abstract}

É nessa perspectiva que Fourez (1995) afirma que assistimos nos últimos séculos a revelação da ciência como um instrumento extremamente poderoso de questionamentos ideológicos, que puseram em questão alguns abusos presentes em discursos éticos, religiosos e políticos; embora o autor admita que a ciência também parte de uma evolução sócio histórica, incapaz de apresentar uma verdade global em substituição aos discursos ideológicos de caráter "obscurantistas". Apesar dos muitos progressos científicos, continuamos a ser ignorantes e que muito falta por aprender.

Para Fourez (1995) o conhecimento não é neutro. Ele é construído no interior de um universo ético e cultural. No próximo capítulo foi feito uma breve retrospectiva da construção do conceito de célula e a partir de algumas reflexões pudemos concluir que o momento histórico em que um determinado conhecimento científico foi produzido é de especial importância no meio escolar. Pois, o professor pode a partir dele, inovar suas aulas, contribuir para o desenvolvimento do pensamento crítico em seus alunos, discutir com os mesmos que as teorias científicas não são definitivas e incontestáveis e não surgem do nada ou já vêm prontas nos livros didáticos.

Nos livros didáticos é dito, por exemplo, que foi o cientista inglês Robert Hooke o primeiro envolvido na visualização das células pela primeira vez, mas eles não dizem e muito provavelmente o professor não saiba quem foi Robert Hooke. O que ele queria quando 
colocou uma fina fatia de cortiça no microscópio? Conforme Prestes (1997), Hooke estava intrigado com o "fenômeno da cortiça", fenômeno este que a fazia ser leve, flutuar e possuir certa elasticidade. Então, esperava que o microscópio favorecesse a compreensão deste material e a elaboração de uma definição científica. Com as observações, ele pode concluir que a "flutuabilidade deve-se ao ar firmemente retido dentro de espaços diminutos e regulares-pequenas "celas", ou "células"”.

É provável que os estudantes não pensem cotidianamente sobre o contexto histórico em que o conhecimento foi produzido e, muito menos desconfiam de como algo antigo pode resolver os problemas de um tempo futuro ou está relacionado àquilo que estão aprendendo hoje e isso não lhe desperte a mínima preocupação. É um bom momento de o professor refletir com eles que o conhecimento científico não são verdades definitivas e incontestáveis e que o mundo está sendo interpretado e reinterpretado diferentemente a cada dia, em diferentes épocas. O mundo hoje é diferente do que era há mil anos. Do que era há cem anos. Do que era há dez anos. Até mesmo do que era há cinco anos, muito por causa da ciência, no entanto vivemos um paradoxo: as pessoas nunca usaram tanto a ciência (e a tecnologia), nunca foram tão dependentes da ciência e, ao mesmo tempo é algo distante para muitas pessoas.

\subsection{Desenvolvimento Social de Ideias em Sala de Aula}

O desenvolvimento social de ideias em sala de aula é basicamente um complemento do primeiro eixo. Mortimer (2006) parte do pressuposto que processos cognitivos individuais não esgotam a análise dos processos socais, sobretudo quando se considera o papel da linguagem. Coutinho (2007) citando Videira (2000) afirma que: "as mais importantes atividades da ciência é a elaboração de teorias - que podem ser entendidas como estruturas linguísticas que tornam possível interpretar aquilo que percebemos ou acreditamos existir no mundo dos fenômenos"

Mortimer (2006) chama à atenção para a sala de aula como um espaço em que pelo menos duas linguagens sociais interagem- a científica e a do senso comum-gerando novos significados, dialogicidade e polifonia (múltiplas vozes). O autor afirma que "para produzir novos significados na interação discursiva é necessário que o professor dialogue com os alunos, permitindo as contrapalavras, a interação entre diferentes vozes” (MORTMER, 2006, P. 162). Na concepção bakhtiniana de linguagem, todo discurso, por meio de várias 
direções ou em seu caminho até o objeto, encontra-se com outros discursos e participa com eles de uma interação viva e intensa. É, pois um fenômeno inerente a qualquer e todo discurso; (BAKHTIN, 1988, p.88) e, portanto, podendo ser aplicado às diferentes fases de aprendizagem incluindo ensino médio, formação inicial e continuada de professores.

A assunção de uma perspectiva dialógica do sujeito e da linguagem nos leva a considerar a multiplicidade de vozes que concorrem na produção do discurso de sala de aula, ou seja, o discurso de sala de aula só pode ser analisado no entrecruzamento de outros discursos que o constituem (o discurso da ciência, o discurso pedagógico, o discurso do aluno, por exemplo). A voz do conhecimento científico, ao se transmutar no discurso de sala de aula em objeto de ensino, o faz no diálogo com categorias de outras formações discursivas, que não apenas a do discurso da ciência (as categorias do senso comum, por exemplo).

Driver (1999) cita dois tipos de aprendizagem para ciência: a) a aprendizagem como atividade individual que considera a construção do conhecimento a partir de esquemas existentes no indivíduo e, b) a aprendizagem envolvendo processos sociais, onde aprender ciências é um processo que vai além da tentativa de ampliar o conhecimento dos jovens sobre os fenômenos e organizar o raciocínio do senso comum; e sim, apresentar e socializar as práticas da comunidade científica, como outra forma de enxergar o mundo.

Em outras palavras, aprender ciências envolve processos pessoais, mas da mesma forma envolve processos sociais. Isso quer dizer que o aluno deva ser introduzido aos conceitos, símbolos e convenções da comunidade científica; no entanto ele não consegue fazer isso sozinho, precisando muito da mediação do professor. Não obstante, a literatura aponta para uma das características mais focalizadas nos cursos de capacitação, na qual os professores entram neles com concepções, crenças e atitudes, tanto sobre o conteúdo do curso - conhecimentos e habilidades - quanto sobre a natureza e o propósito da aprendizagem, portanto é preciso que os professores formadores estejam atentos.

As Ciências Biológicas especificamente é uma área do conhecimento que se vale de muitos termos técnicos, possui linguagem própria que serve para atender ao rigor conceitual e destoar de ambiguidades e imprecisões, todavia, a opacidade dos termos empregados pelos cientistas decorre de se apresentarem carregados de teoria, por mais que pareçam fáceis de entender (MEADOWS, 1999, p. 54). É o caso da palavra fermentação, que, no uso cotidiano, tem um significado simples, entretanto, no âmbito da biologia, apresenta um sentido complexo, por estar relacionada a processos bioquímicos.

Mortimer (1998) explicita o abismo que há entre a linguagem cotidiana e a científica, como aparentemente não há correlação entre a realidade da vida diária e a teoria da ciência, o 
educando só entende o novo significado, que está sendo transmitido em sala de aula, se houver intermediação. É plenamente aceitável dizer, em linguagem coloquial: se não respirarmos oxigênio, morreremos. Usando a modalidade científica, a frase modifica-se: $\mathrm{Na}$ respiração celular, o oxigênio, sendo o aceptor final de elétrons liberados na degradação de moléculas orgânicas, irá formar moléculas de água, e se evitará a morte celular. (p.114-116)

O papel intermediador do professor é fundamental para reduzir dificuldades e apresentar ao estudante esse novo conjunto de símbolos e de linguagens. Encontramos nas DCN (2013) um apoio a esse padrão formal de conhecimento quando lemos que

\footnotetext{
Uma formação integral, não somente possibilita o acesso a conhecimentos científicos, mas também promove a reflexão crítica sobre os padrões culturais que se constituem normas de conduta de um grupo social, assim como a apropriação de referências e tendências que se manifestam em tempos e espaços históricos. (BRASIL, 2013, p. 162).
}

Numa concepção construtivista de educação, o professor não é, nem tampouco pode ser mero espectador da construção de conhecimentos dos alunos. Cabe a ele o papel de organizar as situações de aprendizagem, as intervenções pedagógicas que auxiliem os alunos em suas próprias construções, sem contar à afetividade que se estabelece. Uma das fontes motivacionais do ensino e da aprendizagem está no vínculo estabelecido entre educador e educando. O professor é um interlocutor fundamental para mediar os conhecimentos e os mecanismos pedagógicos, os históricos e os filosóficos envolvidos.

É comum o aluno questionar o professor dizendo: Por que estudar células? Para que preciso saber isso? Por que saber tantos nomes difíceis? Essas perguntas num primeiro momento parecem banais, mas ao contrário deveriam levar a uma reflexão profunda do professor sobre o porquê de realmente se estudar aquele novo conceito. É possível também que o próprio professor não tenha consciência da sua estrutura cognitiva, de que forma ela foi construída ao longo dos anos, sobre esse e outros conceitos que ele vislumbra construir junto ao aluno. Até que ponto essa relação com os alunos, a linguagem científica e outras variáveis interferem na modificação de seu arcabouço de conhecimento e de ver sua própria disciplina?

Quando indagada, costumo afirmar que somos seres vivos, necessitamos de alimentos, nascemos, crescemos, nos desenvolvemos, reproduzimos e morremos. Precisamos ter conhecimento sobre a natureza, de como ela se comporta e de como a vida se processa; afinal, necessitamos nos posicionar com fundamentos acerca de algumas questões que hoje dominam o mundo, entre elas a biotecnologia, que em muitos processos, utiliza células vivas, além da nossa sobrevivência como espécie. Mas, para responder a isso, antes precisei refletir sobre 
esses questionamentos também, enfim, construir o pensamento calcado no que é aceito hoje pela comunidade científica.

Essas perguntas surgem porque o pensamento do aluno sobre o dia a dia, segundo Driver (1999), é pragmático; ou seja, as ideias são julgadas por sua utilidade, associadas geralmente a um fim específico. Já o científico, tem um objetivo de construir um quadro geral e coerente acerca do mundo com modelos mais generalistas e com maior alcance.

Por um lado, os estudantes possuem um repertório de representações, de conhecimentos intuitivos, adquiridos pela vivência, pela cultura e pelo senso comum, acerca dos conceitos que serão ensinados na escola, é preciso considerar que o professor também carrega consigo muitas ideias de senso comum, ainda que tenha bem elaboradas as parcelas do conhecimento científico. Essas ideias, que foram sendo construídas ao longo de sua inserção no contexto escolar - enquanto aluno e fruto de sua história de vida pessoal. Pacca \& Villani (1996) são mais enfáticas e consideram que na fala imaginária de seus alunos, quase sempre estão presentes suas próprias dúvidas e concepções alternativas, que não têm coragem de expor publicamente.

Segundo Mortimer (2006), cada conceito é diferente para cada pessoa devido à influência de diferentes vivências que o indivíduo tem, as quais podem estar relacionadas, por exemplo, a aspectos culturais. Tomo como exemplo os alunos do $8^{\circ}$ ano, em minha prática como professora já presencie alunos que percebem o corpo humano, como o "habitat do espírito", ou como "objeto de desejo e prazer", outros como um "padrão estético de beleza" estipulado principalmente pela mídia. Cada percepção dessas, potencialmente sofreu influência da família, religiosidade, comunidade onde vive e outros

Mortimer (2006) acrescenta que se a ideia de univocidade não é completa num discurso em sala de aula e, se todo entendimento tem aspectos mais ou menos dialógicos, envolvendo sempre uma multiplicidade de vozes, por conseguinte não existem entendimentos únicos relacionados a determinados conceitos.

Se partirmos do pressuposto de que cada indivíduo é singular, ou seja, cada um possui suas próprias crenças, valores e ideologias em relação a tudo ao seu redor, concluímos que os tipos de processos sociais estabelecidos entre as pessoas irão depender de cada um. Esse pensamento encontra eco na própria DCN (2013), quando se esclarece que

A educação destina-se a múltiplos sujeitos e tem como objetivo a troca de saberes, a socialização e o confronto do conhecimento, segundo diferentes abordagens, exercido por pessoas de diferentes condições físicas, sensoriais, intelectuais e emocionais, classes sociais, crenças, etnias, gêneros, origens, contextos socioculturais, e da cidade, do campo e de aldeias. (BRASIL, 2013, p. 20). 
Fazendo uma correlação com esse ponto de vista, uma vez que se preconiza a escola como um espaço baseada no processo de interação, não se pode deixar de pensar acerca dos fenômenos histórico-sociais presentes na atividade profissional do professor, sua identidade ideológica, sua formação intelectual, como ele enxerga sua disciplina. Será que ele se vê um mero transmissor de conhecimentos ou como um mediador, como alguém capaz de articular as experiências dos alunos com o mundo, levando-os a refletir sobre seu entorno? As respostas a essas perguntas implicam ao professor pensar ou repensar o seu processo formativo e sua prática diária.

O ensino de biologia é visto por muitos como uma disciplina caracterizada pela dificuldade de compreensão de seus termos, muitos de origem grega e latina. No entanto, se o professor não tiver claro que o ensino deve fomentar nos alunos a capacidade de construir uma visão ordenada e integrada dessa ciência, ao invés de limitarem-se à compreensão e memorização de termos técnicos, o professor mesmo que involuntariamente, estará reforçando uma ideia equivocada dos termos da biologia, além de prejudicar o ensino da disciplina. 


\section{REFLEXÕES A RESPEITO DO CONCEITO DE CÉLULA}

“Todas as coisas vivas são formadas por células" (ALBERTS, 2011, p.2). Muitos seres vivos são constituídos de uma única célula isolada, como os protozoários. Os demais seres, entretanto, são pluricelulares (formados de muitas células). Eles também nascem de uma única célula, mas a célula inicial divide-se depois em várias outras, que também se subdividem. À medida que elas se multiplicam em diferentes etapas do desenvolvimento, as células resultantes vão se tornando diferentes umas das outras, formando tipos com funções específicas.

\subsection{Breve Histórico}

Desde tempos remotos conceitos rudimentares da célula já apareciam. "Os primeiros a escreverem sobre os seres vivos foram provavelmente os gregos”, (AMABIS, 1999, p.9). Para o filósofo grego Aristóteles (384-322 a.c), a matéria do universo, estando sujeita a um contínuo movimento, passava gradualmente da condição de amorfa e homogênea à de diferenciada e heterogênea, originando sucessivamente os seres minerais, vegetais, animais e, por fim, o homem (princípio da epigênese). Desse modo, seres vivos e não vivos eram formados pelos mesmos elementos básicos (água, terra, ar e fogo).

Segundo Aristóteles e outros pensadores da época: "todos os animais e vegetais, por mais complicados que sejam, estão constituídos por uns poucos elementos que se repetem em cada um deles", mas se diferenciavam quanto ao grau de organização de sua matéria constituinte - nos animais, por exemplo, a matéria estava organizada em níveis sucessivos de complexidade (os elementos básicos compunham tecidos; os tecidos compunham órgãos; os órgãos compunham o organismo). (BASTOS, 1992)

Esse pensamento referia-se às estruturas macroscópicas de um organismo, como as raízes, as folhas e as flores comuns aos diferentes vegetais e aos segmentos ou órgãos que se repetem no reino animal. Muitos séculos mais tarde é que foi descoberto que, por trás desta estrutura macroscópica, existe todo um mundo de dimensões microscópicas, associado ao desenvolvimento da microscopia. Hoje se sabe que a matéria que forma os organismos vivos, embora peculiar, é constituída por partículas semelhantes às que formam a matéria não viva e está sujeita às mesmas leis que regem o universo não vivo. 
Na matéria viva, no entanto, certos elementos químicos estão sempre presentes em grande proporção, como o carbono $(\mathrm{C})$, o hidrogênio $(\mathrm{H})$, o oxigênio $(\mathrm{O})$ e o nitrogênio $(\mathrm{N})$ que, junto com vários outros elementos, em menores quantidades, formam substâncias muito complexas, que constituem os seres vivos. Além de serem sistemas que se auto organizam, evoluindo com o tempo; com capacidade de produzirem energia para manutenção e reprodução.

A história da célula está intimamente relacionada com o desenvolvimento das lentes ópticas e a com a combinação delas para construir o microscópio composto. Sendo a célula de dimensões tão diminutas, o seu conhecimento esteve sempre na dependência do desenvolvimento de métodos apropriados de investigação e de instrumentos de observação que possibilitassem sua visualização. Hoje a microscopia tem aplicações em quase todas as especialidades científicas e em aplicações tecnológicas, o estudante de ciências bem informado deve ter um certo conhecimento do que é o equipamento, suas possibilidades e suas limitações.

(MOSLEY; LYNCE, 2010, p. 208) afirmam que "apesar da tecnologia limitada, Hooke teve êxito em desvelar um mundo desconhecido" Robert Hooke, inglês (1635-1703), criou o microscópio composto, isto é, com duas lentes. O nome célula (do grego kytos, célula; do latim cella, espaço vazio) foi empregado pela primeira vez por ele em 1665, ao observar a textura da cortiça utilizando lentes de aumento.

Nessa época, a Inglaterra passaria a considerá-lo o maior especialista no mundo microscópico. Foi a Hook que os membros da Royal Society recorreram quando chegou um misterioso pacote vindo da Holanda. Tratava-se de cartas e de desenhos de Anton Van Leeuwenhoek, um mercador de tecidos, com pouca conexão com o mundo científico. Ele alegava ter descoberto um mundo oculto, ao inspecionar os tecidos com lentes de aumento caseiras. Posteriormente escreveu para a Royal Society, revelando que havia visto animais minúsculos que ele chamou de "animálculos", observados em seu próprio sêmen (MOSLEY; LYNCE, 2010).

Nessa época, começava a delinear-se o primeiro conceito de célula. A princípio tratava-se de "compartimentos homogêneos e contentores de líquido". A microscopia veio revelar o até então desconhecido mundo dos microrganismos, fornecendo as bases para a teoria celular. Essa ideia foi aceita por muitos pesquisadores, incluindo o patologista R. Virchow. Esse cientista afirmou que toda célula surgia de outra preexistente e resumiu seu 
pensamento em uma frase bastante conhecida: "Omnis cellula ex cellula", que quer dizer "toda célula se origina de outra célula". Vale destacar, no entanto, que Virchow fez essa observação sem ter conhecimento a respeito dos processos de mitose

Em meados do século XIX Robert Brown (1831) estabeleceu que "o núcleo é um componente fundamental e constante da célula". Ele trouxe de uma expedição da Austrália amostras de orquídeas. Ao examiná-las ao microscópio, percebeu que havia algo diferente com coloração mais escura. Ele chamou essa área de núcleo, embora não fizesse a mínima ideia qual era sua função. (MOSLEY; LYNCE 2010)

Ainda no século XIX, um grupo de biólogos notou a importância crucial das células. Para Bastos (1992)

O debate das questões focalizadas pelos filósofos da natureza e o acúmulo de evidências favoráveis à natureza celular dos tecidos de animais e plantas conduziram à formulação de um conceito rudimentar de célula viva expresso primeiramente (1839) através da teoria celular de Schleiden e Schwann. (BASTOS, 1992, p.64)

Schleiden e Schwann promoveram as noções da célula como: $i$ ) a unidade básica do organismo; $i$ ) cada célula individual contém todas as características essenciais à vida, embora se tenham inicialmente oposto à ideia de que todas as células nascem a partir da divisão de outras células e Schwann descreveu os animais como uma iii) "cooperativa de células", cada uma agindo independentemente, mas ao mesmo tempo, trabalhando juntas em prol do todo. (MOSLEY; LYNCE, 2010, p.211).

Bastos (1992) afirma que a teoria celular foi objeto de grande controvérsia. Embora a generalização de que plantas e animais são compostos de células tenha sido relativamente bem aceita, não houve consenso possível a respeito da ideia de célula autônoma, contudo, graças ao posterior trabalho de Robert Remak e Rudolf Virchow, na década de 1860, estas três premissas eram já consensuais entre a comunidade científica e estariam na origem do que viria a ser a teoria celular.

Uma das primeiras generalizações feitas no estudo dos seres vivos diz que "todos os seres vivos são constituídos por células" e é considerada a mais ampla e fundamental de todas as generalizações biológicas Esse enunciado constitui a chamada Teoria Celular (Schwann, 1839). A teoria celular forneceu uma nova perspectiva sobre os pilares fundamentais da vida, estabelecendo que "cada célula se forma por divisão de outra célula".

Outros investigadores, como Purkinje, Von Mohl (1846) concentraram-se na descrição do conteúdo celular denominado de protoplasma. Assim, o conceito primitivo de célula 
transformou-se no de "uma massa de protoplasma, limitado no espaço por uma membrana celular e que possui um núcleo".

Em meados do século XIX, por volta de 1869, o interior do núcleo passou a atrair mais atenção, com a difusão da "teoria dos germes" e a crescente tese que os germes podiam matar. O bioquímico alemão Johann Friedrich Miescher (1844 - 1895) buscava determinar os componentes químicos do núcleo celular e usava os glóbulos brancos contidos no pus para suas pesquisas. Segundo Mosley e Lynce (2010) o pus era muito fácil de conseguir na época em ataduras usadas em ferimentos de guerra. Naquela época a Alemanha travava uma guerra contra a Prússia.

Analisando os núcleos, Miescher descobriu a presença de um composto de natureza ácida que era desconhecido até o momento. Esse composto rico em fósforo e em nitrogênio era desprovido de enxofre e resistente à ação da pepsina (enzima proteolítica); aparentemente era constituído de moléculas grandes, foi denominado, por Miescher, nucleína. Miescher começou a procurar em outras células, incluindo rãs e salmões. Nove anos depois, Richard Altmann (1852 - 1900), que era aluno de Miescher, obteve a nucleína com alto grau de pureza, comprovando sua natureza ácida e dando-lhe, então, o nome de ácido nucléico (MOSLEY; LYNCE, 2010, p. 216)

A disciplina citologia nasceu dos trabalhos dos cientistas do século XVII cujos estudos ficaram por conta da morfologia e da divisão celular que foram progredindo por meio de investigações. Tais eventos possibilitaram originar, a partir de 1930, uma nova disciplina - a biologia celular - impulsionada desde então pelas descobertas da bioquímica. Com o progresso da bioquímica, foi demonstrado que existem semelhanças fundamentais na composição química e atividades metabólicas de todas as células. Também foi reconhecido que o funcionamento de um organismo como um todo resulta da soma de atividades e das interações das unidades celulares.

Alberts et al. (2011, p. 4) nos dias de hoje, descreve algumas características conceituais sobre células que estão em vigor. Ele afirma, por exemplo, que

a) todas as células guardam sua informação hereditária no mesmo código químico linear (DNA);

b) todas as células replicam sua informação hereditária por polimerização a partir de um molde;

c) todas as células transcrevem partes de informação hereditária em uma mesma forma intermediária (RNA);

d) todas as células usam proteínas como catalisadores; 
e) todas as células traduzem o RNA em proteínas da mesma maneira

f) todas as células são envoltas por uma membrana plasmática através da qual devem passar nutrientes e material descartáveis;

g) uma célula viva pode existir com menos de 500 genes.

As pesquisas sobre células avançam, Alberts (2011) cita, por exemplo, como os avanços da ciência na tentativa de combater o câncer levaram a várias descobertas. $\mathrm{O}$ autor salienta a importância dessas descobertas, por serem fundamentais na biologia das células, pelo fato de as células cancerosas violarem as regras básicas de comportamento pelos quais organismos multicelulares são construídos e mantidos. Não raro, células cancerosas estão associadas a anomalias de proteínas, dentre elas aquelas envolvidas no reparo do DNA, na sinalização celular, no ciclo e no crescimento celular, na morte programada e na arquitetura tecidual.

O avanço dos estudos da célula sempre esteve atrelado ao avanço da microscopia. Em 2014 a revista Pesquisa Fapesp informou que dois norte-americanos e um alemão ganharam o Nobel de Química por permitirem que microscópios enxerguem estruturas minúsculas dentro de células vivas. Desde o século XVII, microscópios ópticos viabilizaram o estudo de microrganismos, mas só até certo ponto. A microscopia óptica convencional tem uma limitação física para a luz visível, esse limite é de 0,2 mícron (milésimo de milímetro)

Segundo a revista, a barreira do 0,2 mícron persiste, mas os três cientistas encontraram uma maneira de driblar seus efeitos. Isso graças à capacidade de marcar as moléculas biológicas, acoplando-as a uma proteína, chamada GFP, que em certas condições se torna fluorescente. As descobertas de Betzig, Moerner e Hell transformaram a microscopia em nanoscopia. 


\section{METODOLOGIA}

A presente pesquisa foi dividida em três momentos: um anterior à utilização da estratégia de ensino, que ocorreu com aplicação de um questionário com questões abertas, que foi chamado de pré-teste (Apêndice 2); o segundo imediatamente após a aplicação do préteste, definido como estratégia de ensino e o terceiro momento, próximo ao final do ano letivo, denominado pós-teste. (Apêndice 3), as etapas estão resumidas na figura:

Figura 4: Etapas gerais da pesquisa

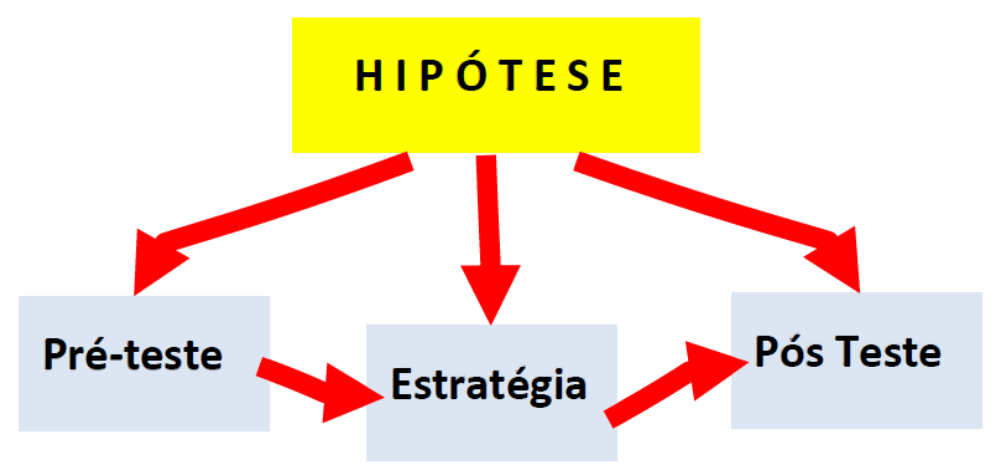

No pré-teste um questionário foi preenchido pelo aluno, no qual foram colocados cinco itens abertos a respeito de célula, sendo respondido na presença da pesquisadora, sem que os alunos fizessem qualquer consulta aos colegas ou ao material. Cada questionamento apresentava uma exposição verbal explicativa feita pela professora para facilitar a compreensão e o preenchimento do pesquisado, de modo que o aluno ficasse o mais independente possível.

Foi disponibilizado um tempo de aula de 45 minutos para que os alunos respondessem às questões e também foi orientado que não se preocupassem com o gabarito. A intenção era convidá-los a demonstrar seu conhecimento a respeito do assunto e tentar entender qual a visão deles sobre o tema. Também foi dito que eles podiam se expressar a vontade (escrevendo, desenhando, esquematizando, fazendo modelos).

É importante ressaltar que não havia nenhum gabarito ou modelo para definir se as respostas estavam certas ou erradas. Assim, os critérios utilizados na avaliação das respostas foram os seguintes: se as ideias do aluno se aproximavam da resposta cientificamente aceita atualmente para aquela pergunta e a explicitação das ideias dos estudantes em relação ao conceito de célula, sejam os oriundos da percepção do professor, seja aqueles já identificados 
em pesquisas anteriores, embora para cada questão indiquemos conceitos básicos que foram considerados adequados para cada questão (quadro 1).

Quadro 1: Conceitos avaliados

\begin{tabular}{|c|l|}
\hline Questões & \multicolumn{1}{c|}{ Conceitos Avaliados } \\
\hline 1 & $\begin{array}{l}\text { Conhecimentos a respeito da célula como unidade fundamental de todos os } \\
\text { seres vivos - Teoria Celular. }\end{array}$ \\
\hline 2 & $\begin{array}{l}\text { Conhecimentos a respeito de crescimento, de multiplicação, de divisão } \\
\text { celular. }\end{array}$ \\
\hline 3 & $\begin{array}{l}\text { Conhecimentos a respeito de diferenciação celular, de forma, de tamanho, de } \\
\text { especialização. }\end{array}$ \\
\hline 4 & $\begin{array}{l}\text { Conhecimentos a respeito do agrupamento das partes menores da célula que } \\
\text { irão constituir as estruturas mais complexas-pensamento sistêmico }\end{array}$ \\
\hline 5 & $\begin{array}{l}\text { Conhecimentos a respeito de termos científicos /informais/espontâneos } \\
\text { associados a células }\end{array}$ \\
\hline
\end{tabular}

\section{Questões de estudo (pré-teste)}

Para confecção das questões, partiu-se da premissa que aquilo que o aprendiz já conhece influencia sua aprendizagem, por isso a importância de descobrir o que ele sabe, ou seja, suas concepções prévias e basear a mediação da aprendizagem (MORTIMER, 2006). Identificaram-se os conhecimentos prévios dos alunos a respeito de células por meio da aplicação de um questionário para que eles expressassem o que achavam de que biologicamente somos feitos; se todos os seres vivos têm o mesmo número de células; se as células são todas iguais. Também foram elencados alguns termos: DNA, célula, gene, cromossomo, organismo e núcleo, e eles tinham que colocar a sequência das estruturas pelo tamanho (partindo do maior para o menor) que julgassem mais corretos e por fim associassem o termo célula a duas palavras.

Mortimer (2006) destaca a aplicação de um questionário exploratório, como expediente importante para revelar possíveis obstáculos, que deverão ser discutidos no processo de ensino. Os obstáculos aqui mencionados podem ser entendidos como aqueles que de algum modo interferem no processo de ensino-aprendizagem. Como afirmam Roza e Schnezler (1998): "a luz da epistemologia bachelardiana, as concepções alternativas ou prévias que os 
alunos apresentam no processo de ensino podem ser vistos como obstáculos epistemológicos".

Respeitando as orientações do PSD e seguindo a metodologia de ensino proposta pela TPC, as aulas foram planejadas, selecionando-se problemas que correspondessem a situações a interpretar a partir das respostas dos alunos e utilizando diferentes métodos ativos (como discussões, textos, comparação de informações, esquemas produzidos pelos alunos, laboratório entre outros).

Libâneo (2013), salientando a importância do planejamento das aulas, afirma que " $a$ aula é a forma didática básica de organização do processo de ensino”, o autor acrescenta que ela não se aplica apenas à aula expositiva, mas a todas as formas didáticas e às estratégias organizadas e dirigidas, tendo em vista realizar o ensino e a aprendizagem. Pode parecer em um primeiro momento que utilizar uma aula para aplicar um teste exploratório acerca das ideias dos alunos sobre o fenômeno em questão possa ser "perda de tempo", mas no decorrer do processo mostrou ser um instrumento eficaz.

Na segunda aula, os alunos foram separados em grupos. A partir daí, foi enfatizado a importância de cada aluno conhecer as respostas dos colegas para que pudessem eleger qual das respostas do questionário aplicado eles consideravam mais coerente. MORTIMER, 2006 O objetivo dessa estratégia era explicitar a visão dos alunos. $\mathrm{O}$ aluno então era convidado e reconhecer suas definições em meio a outras e conhecer as definições dos seus pares. A partir daí houve uma redução do mosaico de ideias. Num processo de identificação de concepções espontâneas, onde 165 alunos responderam o questionário, agrupamos uma média de concepções mais convergentes

Na terceira aula, o professor de posse dos esquemas previamente selecionados pelos próprios alunos pôde verificar com mais clareza onde estavam os erros conceituais mais expressivos, a influência das concepções espontâneas e quais respostas apresentava um padrão de repetições mais comum. O trabalho original da Teoria do perfil Conceitual (TPC) investigou o fenômeno de transformação da matéria, onde os alunos foram requisitados a desenhar modelos para um sistema antes e depois da transformação. Na nossa pesquisa, no entanto, trabalhamos com células, não objetivamos a verificação de nenhum processo de transformação celular, como ocorrem, por exemplo, em células cancerosas ou em 
manipulações gênicas. Consideramos a célula em interfase ${ }^{4}$ somente. Todavia, nos apropriamos da abordagem da TPC e de igual modo solicitamos que os estudantes pensassem o modelo de uma célula ou a descrevesse como se estivessem vendo através de poderosas lentes de aumento, porém, evitamos solicitações do tipo "imagine como seria a célula", a fim de, não reforçar respostas sensorialistas, já que célula representa modelos construídos cientificamente, ao mesmo tempo em que se preservou o objetivo de suscitar as intuições dos estudantes sobre células. MORTIMER, 2006

Nas aulas subsequentes, os passos didáticos escolhidos, com base na TPC, podem ser assim generalizados:

I) a própria preparação do professor, buscando conhecer a história pela qual o conceito de célula foi construído, além de assegurar que o tempo e aplicação da estratégia fossem cumpridos.

II) introdução do conteúdo de célula, onde foi feito o entrelaçamento com o que os alunos já conheciam a respeito, sempre explicitando ao máximo as ideias que eles trouxeram;

III) tratamento da matéria nova, a qual teve como objetivo ajudar os alunos a tomar consciência de novas alternativas conceituais, sistematiza-las e como destaca Coutinho (2005): “o sucesso no ensino de uma ciência, como a biologia, deve ser medido pela capacidade do estudante de construir uma visão integrada e ordenada das redes de significados e práticas que constituem aquela ciência”. Buscávamos que o aluno conseguisse no $8^{\circ}$ ano, especificamente integrar o conceito de célula ao estudo do corpo humano.

IV) consolidação e aprimoramento dos conhecimentos. Não estávamos preocupados em realizar uma ruptura com as concepções prévias dos alunos, mas um enriquecimento de seus perfis conceituais, acompanhado por uma demarcação clara dos domínios de aplicação de cada modo de pensar e de falar. (COUTINHO, 2005). Era preciso que os conhecimentos novos fossem organizados, a fim de que estivessem disponíveis para orientá-los nas situações concretas de estudo e de vida.

Recorremos a todos os meios didáticos disponíveis (exercícios, modelos de células, aula de microscopia, estudo dirigido, trabalhos em grupos, internet). Sempre buscando que o aluno estabelecesse comparações entre o estudo com os fatos da vida real. Pedimos por exemplo, que o aluno com o auxílio do livro didático ou da internet montasse um glossário

\footnotetext{
${ }^{4}$ Amabis e Martho (1999) definem interfase como o intervalo entre duas divisões celulares.
} 
com as palavras: célula, unicelular, pluricelular, eucarionte, procarionte e outros. Ao final da pesquisa foi elaborado uma proposta de intervenção, onde detalhamos mais os meios utilizados.

V) controle e avaliação, aqui foi o momento de buscar observar se eles eram capazes de utilizar autonomamente conhecimentos e habilidades adquiridos, embora conscientes de que essa medida é um componente abstrato de difícil percepção. Para Mortimer (2006)

é fundamental que o aluno seja capaz não só de usar as novas ideias em situações conhecidas, mas também se a generaliza em situações novas e as utiliza para resolver um problema potencialmente perturbador o que indicaria certo grau de estabilidade da nova concepção. (MORTIMER, 2006, p.177)

Utilizamos alguns instrumentos de avaliação próprios do CMB: Instrumento Parcial de Avaliação (IAP), cujo caráter é mais imediato e a Avaliação de Estudo (AE) aplicado ao final do bimestre, além do pós-teste que será abordado no quinto capítulo (Resultados e Discussões), buscando sempre que possível acompanhar a capacidade de generalização dos alunos, a respeito dos conceitos celulares cientificamente aceitos hoje.

Figura 5: Resumo das etapas da TPC

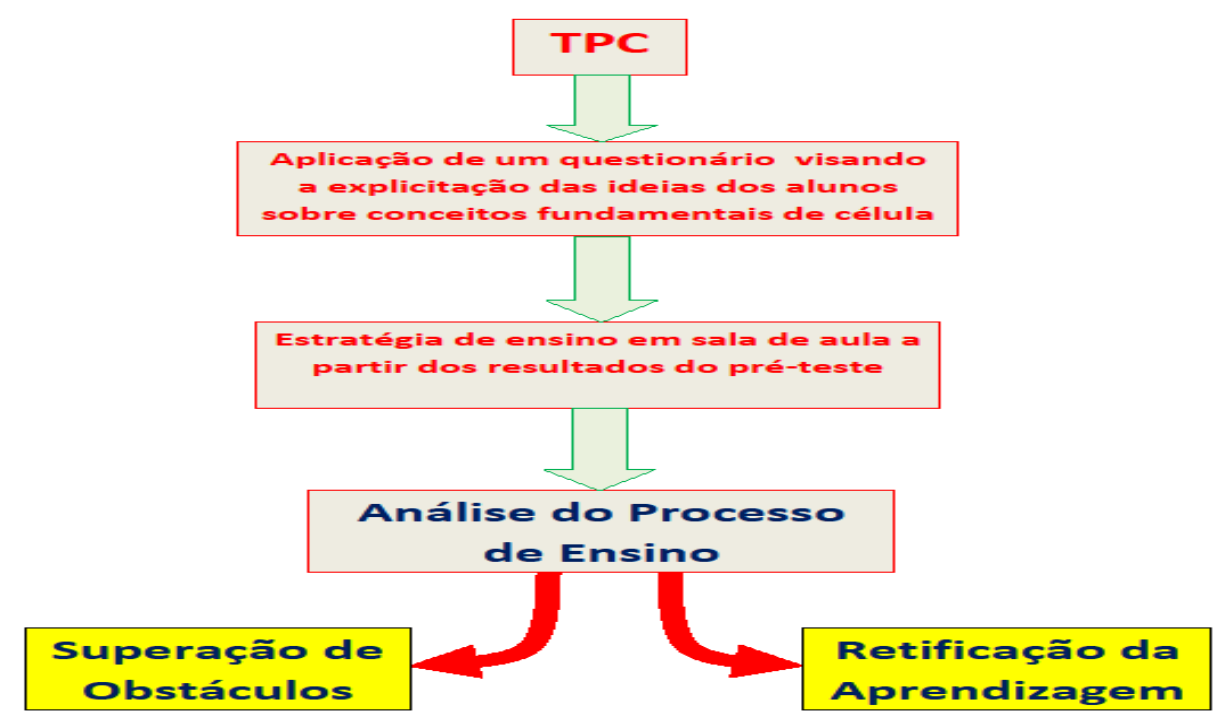

4.1 Local de pesquisa, delimitação do universo e procedimentos.

A pesquisa ocorreu em cinco salas de aula do $8^{\circ}$ ano do Colégio Militar de Brasília (CMB). O CMB é uma instituição que tem uma infraestrutura relativamente equipada, quando comparada com outras instituições públicas do país: são 12 salas de aulas destinadas ao $8^{\circ}$ 
ano, uma biblioteca muito bem estruturada, não somente pelo prédio em si, mas também pelo seu acervo, com livros de literatura, didáticos, além de outros meios de comunicação como jornais e revistas, sendo algumas produzidas pela própria Instituição (revista "O Saber" e" Garança Poética"), na qual todo e qualquer material pode ser utilizado tanto pelo aluno quanto pelo professor; um laboratório de informática amplo.

O CMB também possui laboratório de Ciências e um laboratório de Biologia equipados com microscópios e modelos do corpo humano, que podem ser utilizados na sala de aula ou no próprio laboratório, incluindo modelos de células animais e vegetais.

Deve-se salientar a influência da diversidade no ambiente escolar, pois muitos desses alunos são oriundos de outros colégios militares, outras escolas públicas, particulares e até mesmo do ensino a distância do próprio SCMB, no caso daqueles cujos pais servem na fronteira ou estão em missões de paz. Assim, o propósito geral nessa pesquisa também contempla uma metodologia de investigação que dá ênfase à descrição e ao estudo das percepções dos sujeitos envolvidos na pesquisa. Portanto, ao valorizar os aspectos descritivos e as percepções pessoais, a pesquisa qualitativa nos oferece maiores possibilidades de compreender os fenômenos, a partir do contexto em que estes se encontram e com especial atenção as especificidades típicas das escolas que compõe a referida rede.

Para a pesquisa foi elencado um universo composto por 165 alunos, com idades que variavam entre 12 e 150 anos. A maioria dos alunos vieram de diferentes regiões do país, devido ao processo de transferência típico da atividade militar dos pais. Outro aspecto importante a ser destacado é o fato de atuar nessa instituição, facilitando, assim, o acesso à pesquisa. $\mathrm{O}$ CMB oferece ensino fundamental e médio, nos períodos matutino e vespertino. Possuo licenciatura plena em Ciências Biológicas e especialização em Biotecnologia. Atuo como professora de Biologia na rede pública há 16 anos, sendo 11 no próprio SCMB.O Quadro 2 resume o percurso metodológico: 
Quadro 2: Resumo do percurso metodológico

\begin{tabular}{|c|c|c|c|c|}
\hline & Etapas & \multicolumn{2}{|c|}{ Planejamento / Execução } & Universo \\
\hline \multirow{7}{*}{$\begin{array}{l}\text { Percurso } \\
\text { metodológico }\end{array}$} & \multirow{5}{*}{$\begin{array}{c}1^{\mathrm{a}} \\
\text { Etapa }\end{array}$} & $\begin{array}{l}\text { Conscientização do } \\
\text { problema: A dificuldade dos } \\
\text { alunos do } 8^{\text {o }} \text { ano na apreensã } \\
\text { do conceito de célula viva }\end{array}$ & \multirow{5}{*}{$\begin{array}{l}\text { Implicações da pesquisa: } \\
\text { a) Conhecer os eventuais obstáculos } \\
\text { que dificultam a aprendizagem dos } \\
\text { conhecimentos científicos } \\
\text { especificamente sobre células no } \\
\text { estudo do corpo humano. } \\
\text { b) A partir daí elaborar uma } \\
\text { proposta que auxilie professores no } \\
\text { estudo a respeito da célula. } \\
\text { Obs. As discussões em sala foram } \\
\text { uma constante. }\end{array}$} & \\
\hline & & $\begin{array}{l}\text { Importância: A necessidade } \\
\text { de consolidar um conceito } \\
\text { chave no estudo do corpo } \\
\text { humano. }\end{array}$ & & $\begin{array}{c}165 \\
\text { participantes }\end{array}$ \\
\hline & & $\begin{array}{l}\text { Objetivo: Desenvolver uma } \\
\text { estratégia de ensino, a partir } \\
\text { dos pressupostos da Teoria } \\
\text { do Perfil Conceitual }\end{array}$ & & \\
\hline & & $\begin{array}{l}\text { Questionário Exploratório- } \\
\text { Pré-teste }\end{array}$ & & \\
\hline & & $\begin{array}{l}\text { Explicitação de ideias dos } \\
\text { alunos a respeito de célula } \\
\text { viva }\end{array}$ & & \\
\hline & $\begin{array}{c}2^{\mathrm{a}} \\
\text { Etapa }\end{array}$ & $\begin{array}{l}\text { - Analisar a apreensão de } \\
\text { conceitos sobre célula } \\
\text { viva antes e após a } \\
\text { mediação pedagógica. } \\
\text { - Atividades para o ensino } \\
\text { de conceitos celulares } \\
\text { em decorrência da } \\
\text { aplicação da teoria. }\end{array}$ & $\begin{array}{l}\text { Testando a hipótese } \\
\text { a) Observações do comportamento } \\
\text { dos alunos nas aulas; } \\
\text { b) Resultados dos Instrumentos de } \\
\text { medidas do IFE (IAP, AE) }\end{array}$ & $\begin{array}{c}165 \\
\text { participantes }\end{array}$ \\
\hline & $\begin{array}{c}3^{\mathrm{a}} \\
\text { Etapa }\end{array}$ & $\begin{array}{l}\text { Os resultados do pós-teste- } \\
\text { As ideias dos alunos acerca } \\
\text { de conceitos celulares após o } \\
\text { ensino e sua estabilidade }\end{array}$ & $\begin{array}{l}\text { Conclusões } \\
\text { Elaboração de uma proposta de } \\
\text { intervenção didática para } \\
\text { professores do } 8^{\circ} \text { ano. }\end{array}$ & $\begin{array}{c}132^{6} \\
\text { participantes }\end{array}$ \\
\hline
\end{tabular}

Fonte: Resumo feito a partir de modelo adaptado do livro A construção do saber de Christian Laville (página 84)

4.3 Procedimentos em sala de aula

As aulas de ciências na CMB estão sob a tutela da disciplina denominada Ciências Físicas e Biológicas (CFB) e acontece três vezes por semana com duração de 45 minutos cada aula. Segundo os pressupostos dos trabalhos de Mortimer (2006), para o desenvolvimento da

\footnotetext{
${ }^{5}$ IAP (Instrumento parcial de avaliação), AE (avaliação de Estudo). A AE acontece no fim de cada bimestre. Ambos foram adaptados para servirem de avaliação das estratégias aplicadas.

${ }^{6}$ Um aluno mudou para outra sala fora da pesquisa, o outro acompanhou o pai transferido para Inglaterra e um terceiro foi transferido ao longo do bimestre e no quarto bimestre uma turma passou para outro professor.
} 
estratégia foi considerado, já na primeira aula, a aplicação do pré-teste a cinco turmas do $8^{\circ}$ ano.

$\mathrm{Na}$ segunda aula, a turma foi organizada em grupos na sala, pois isso facilitou a condução de trabalhos e promoveu maior interação entre os alunos. De acordo com Piletti (1997, pág. 115) "o trabalho em grupo oferece a oportunidade de estabelecer troca de ideias e opiniões, desenvolvendo as habilidades necessárias à prática da convivência com as pessoas". Utilizando a perspectiva de Mortimer (2011, pág. 170) várias ideias mais representativas que apareceram no pré-teste foram selecionadas. Alguns alunos fizeram modelos esquemáticos de células (6), a maioria respondeu em forma de texto (159).

Havia em média, por sala, seis grupos com aproximadamente cinco alunos em cada um. A formação dos grupos foi espontânea. Os resultados foram distribuídos e os alunos eram convidados a reconhecer seu próprio questionário. Foi sugerido que voluntários do grupo lessem sua resposta para os demais do grupo.

Durante todo período das aulas havia uma interação do professor com cada grupo, seja respondendo questionamentos, dialogando ou apenas com a presença, observando as trocas de ideias entre os membros do grupo. Segundo Pilette

$\mathrm{O}$ ato pedagógico não pode ser simplesmente o ato de uma incitação intelectual ao conhecimento; é também uma forte relação afetiva entre o professor e os alunos, relação afetiva que deve ser vivida com todas as dificuldades que pressupõe (PILETTE, 1997, p. 234).

Nessa linha de pensamento, Sepulveda (2010) afirma que num primeiro momento esse modelo foi desenvolvido para verificar a evolução conceitual do aprendiz ao longo do tempo, mas passou a abranger também a interação dos alunos entre si, num espaço social como a sala de aula e entre esses e o professor.

Ainda na segunda aula, as atividades foram conduzidas no sentido de fazer com que os alunos decidissem qual o melhor modelo para explicar o fenômeno em questão. Cada grupo deveria chegar a um consenso. (MORTIMER, 2011) Duas das cinco turmas tinham tempos de aula dupla. Então essa etapa pôde ser concluída facilmente e ser iniciada a próxima fase. As outras três turmas precisaram de mais tempo de aula.

A terceira etapa foi a mais longa e requereu mais habilidade na condução das atividades, como a capacidade do professor em identificar os alunos mais tímidos, cujas ideias também precisaram ser explicitadas, aqueles alunos mais ativos que demonstram uma grande variedade de interesses e curiosidades, enfim, habilidade para reconhecer e responder à diversidade, acolher as diferentes potencialidades (alguns alunos se expressam com mais 
clareza) e habilidade para fazer as conexões necessárias do senso comum ao conhecimento científico.

Essa fase foi caracterizada por uma discussão geral com a classe, com as respectivas conclusões parciais alcançadas, ou seja, qual o modelo escolhido se aproximava mais do conceito científico e onde o foco deveria ser maior. Mortimer (2011) reporta a necessidade de o professor fazer referência explícita aos obstáculos percebidos, pois esses podem representar justamente a dificuldade que impede a aceitação da nova ideia. Bachelar (1996) já mostrava preocupação com essas dificuldades e a necessidade do professor está ciente disso. 


\section{Resultados e Discussões}

A finalidade do primeiro questionário foi de investigar os conhecimentos prévios a respeito do tema proposto para as aulas: a Célula. Finalizadas as aulas, aplicou-se novamente o questionário para se determinar em que medida houve ampliação dos conhecimentos científicos ou como esses novos conhecimentos conviviam com os conceitos alternativos trazidos por eles. Para efeito didático, à medida que analisarmos os resultados do pré-teste, paralelamente faremos as discussões e ao final do capítulo retomaremos aos resultados do pós-teste.

A explicitação das concepções alternativas, segundo a TPC não objetiva mudá-las e sim ampliar as explicações acerca dos fenômenos da natureza por meio de outros modelos explicativos, por exemplo, ao apreender o conceito de célula, é possível que paralelamente o aluno compreenda melhor a microscopia, já que a evolução desse conceito caminhou junto com o recurso tecnológico, tendo assim mais embasamento para a reflexões sobre questões éticas implícitas nas relações entre Ciência, Sociedade e Tecnologia.

Durante o amadurecimento da pesquisa e no próprio dinamismo da utilização da metodologia percebemos que algumas perguntas que não foram feitas, seriam mais esclarecedoras ou mais complementares que outras, por exemplo: "O que você acha que seja célula" ou ainda " para você qual a diferença entre célula viva e célula morta". Pela falta de oportunidade não foram feitas formalmente no pré-teste e sim no decorrer das aulas. Outro aspecto ratificado durante a pesquisa e que se configurou relevante na prática pedagógica foi o olhar sistêmico ao conceituar células, na qual envolve não somente os conceitos propriamente ditos, mas a estrutura, a função, a reprodução e o ciclo celular e suas conexões com tecidos e órgãos, obviamente respeitando o amadurecimento cronológico do aluno e o currículo do $8^{\circ}$ ano.

As respostas dadas foram de forma geral bem heterogêneas, todavia, apenas algumas foram selecionadas e separadas em categorias, por apresentarem um padrão de repetições maior que as outras. O objetivo dessa categorização foi observar as concepções a respeito de células mais comuns e fazer um balanço das ideias cognitivas encontradas, verificando assim, a possibilidade de que aquela concepção possa ser ou não a causa da dificuldade. (MORTIMER, 2006) Já Giordan e Vecchi (1996) afirmam que nem todos os obstáculos são reais, pois alguns o aluno "pode apoiar-se nele para dar um passo na construção do saber". 
O resultado das definições dos alunos da 80 série foi agrupado considerando a mesma natureza das respostas e o tipo de pergunta. Os resultados demonstraram alguma insegurança ou falta de conhecimento acerca do tema, observado devido ao grande número de questões sem respostas, além de vários erros conceituais e outros que podem ser considerados obstáculos à construção de significado do conceito científico. As respostas foram analisadas e classificadas em quatro classes: respostas corretas; respostas incorretas; respostas incompreensíveis e questões não respondidas ou incompletas conforme apresentado no quadro 3:

Quadro 3: Resumo das respostas

\begin{tabular}{|c|c|c|c|c|c|}
\hline Itens & Corretas & Incorretas & Incompreensíveis & $\begin{array}{l}\text { Não respondidas/ } \\
\text { Incompletas }\end{array}$ & \% de Acertos \\
\hline 1 & 53 & 15 & 09 & 88 & 32,12 \\
\hline 2 & 36 & 58 & 04 & 67 & 21,81 \\
\hline 3 & 112 & 27 & 02 & 24 & 67,88 \\
\hline 4 & 11 & 138 & 00 & 16 & 6,67 \\
\hline
\end{tabular}

Como a quinta questão era de livre associação de palavras não foi mensurada na tabela

Para efeito de comparação, foi feito um levantamento dos perfis já verificados na literatura em pesquisas sobre perfil conceitual do conceito de "vida" e de "adaptação". A partir daí foram elencadas três categorias que possivelmente abarquem as respostas dadas pelos estudantes.

1) A categoria "essencialismo" segundo Coutinho (2006) "é aquela que se baseia em listar propriedades, entendidas como condições necessárias e suficientes para que algo possa ser nomeado como vivo" Em seus trabalhos ele ainda categorizou dois tipos de essencialismo: a macroscópica e a microscópica.

2) O "realismo" que segundo Mortimer (1996), "é basicamente o pensamento do senso comum". Foram observadas, por exemplo, algumas respostas que traziam implicitamente uma conotação de crenças e de dogmas, que se mostram menos susceptíveis à intervenção. Quando por exemplo o aluno respondeu que "viemos do pó" ou "somos feitos de carne e osso"

3) O "racionalista" Para esta zona, consideramos concepções que se enquadram em um nível racional de compreensão do conceito. "somos feitos de células"

A primeira questão - "Biologicamente, do que você acha que somos feitos?" - É uma questão de natureza aberta, objetivou suscitar uma diversidade significativa de respostas, mas 
esperávamos especificamente que os alunos associassem o termo "biologicamente" à célula e respondessem que somos feitos de células. Seguem as respostas da primeira questão no quadro 4:

Quadro 4: Respostas dos estudantes a primeira questão

\begin{tabular}{|c|c|c|c|}
\hline \multicolumn{2}{|c|}{ Categorias } & $\begin{array}{c}\text { Forma que os alunos expressaram } \\
\text { suas ideias }\end{array}$ & Percentual \% \\
\hline \multicolumn{2}{|l|}{ Realismo } & $\begin{array}{l}\text { "somos feitos de carne e osso" "do pó } \\
\text { da terra" }\end{array}$ & 14,55 \\
\hline \multirow{2}{*}{ Essencialismo } & Macroscópico & $\begin{array}{l}\text { de órgãos e sistemas" "de muitos } \\
\text { órgãos" }\end{array}$ & 35,15 \\
\hline & Microscópico & $\begin{array}{l}\text { "de genes", "de microrganismos" "de } \\
\text { matéria orgânica" "de DNA" }\end{array}$ & 7,88 \\
\hline \multicolumn{2}{|c|}{ Resposta objetiva-Racional } & "somos feitos de células" & 32,12 \\
\hline
\end{tabular}

Algumas respostas não apresentavam padrão e aparentemente não formaram categorias ou pelo menos não conseguimos detectar nenhuma tendência, mas devido a sua natureza sui generis destacamos alguns fragmentos para demonstrar a diversidade de pensamentos em apenas uma questão:

“somos feitos de organismos” (4 alunos) Há uma confusão nos níveis de organização dos seres vivos

“ nosso corpo é feito de milhões de microrganismos” (6 alunos)

“ nosso corpo é feito de milhões de bactérias" (3 aluno) É possível que o aluno saiba que bactérias são células, mas utiliza uma linguagem imprópria ao se referir ao corpo humano.

"somos feitos de massa" (1 aluno)

"somos feitos de muitos espermatozoides" (1 aluna)

No quesito incompleto/ não respondido, embora os alunos tenham respondido que somos feitos de células, confundiram conceitos de células com tecidos e órgãos. Por exemplo, responderam que somos feitos de "células e neurônios" ou de "células, órgãos, pele e ossos". Como se ossos e pele não fossem órgãos feitos de tecidos celulares ou como se neurônio não fosse célula.

A segunda questão- " Você acha que todos os seres vivos têm o mesmo número de células?" A ideia era verificar as concepções dos estudantes em relação a um dos fundamentos da biologia, de que todos os seres vivos são formados por células: apenas uma nos organismos unicelulares, muitíssimas nos pluricelulares. 
A maioria das respostas atendeu a nossa perspectiva quanto à natureza pluricelular dos seres vivos, todavia ao justificar as respostas outros aspectos foram explicitados com relação à diferenciação e divisão celular. As respostas faziam alusão à célula como componente independente do corpo. Selecionamos algumas respostas que apareceram com maior frequência de maneira incorreta:

“...assim como nós, as células vão morrendo” o aluno dissocia células do próprio organismo.

"quando você cresce as células dentro de você também crescem”

"todos os dias algumas células do nosso corpo morrem, mas depois elas nascem de novo”. Novamente o aluno dissocia células do próprio organismo.

"à medida que ficamos mais velhos, as células aumentam ou diminuem de tamanho”. A célula como estrutura estática, no que se refere a divisão celular e apoptose.

"todo mundo é igual por dentro"

"existem pessoas com quantidade de massa menor"

"tem pessoas que já nascem sem algumas células"

"quando envelhecem algumas células param de funcionar e não contam”

"a cada dia todo ser humano vai adquirindo mais células"

"a célula pode procriar e nem sempre dão a mesma quantidade de crias"

“com o tempo vai aparecendo mais células, é só o bebê esperar”.

“não, por que os genes são diferentes”.

A terceira questão- "As células são todas iguais"?. O objetivo era verificar a percepção que o aluno tem a respeito da diversidade de formas, funções e tamanhos das células. Tratando-se de célula, vale ressaltar que, por ser microscópica, sua presença e observação não são tão óbvias para os alunos. Mesmo com a utilização de inúmeros livros de biologia, que contêm representações em formas de fotografias, de desenhos e de esquemas representando toda a gama imaginável de escalas, secções e idealizações de organelas de suas estruturas e seus componentes, os alunos possuem dificuldades na hora de interpretar ou desenhar suas observações.

As respostas de um modo geral atenderam a expectativa quanto ao conceito avaliado. A maioria respondeu que "não, pois as células têm funções diferentes, por isso são diferentes”. Essa diferença repousa essencialmente na forma e na função. Uma resposta recorrente diz que: "sim, pois todas as células são redondas”. A padronização de um único 
tipo de célula é relativamente comum no imaginário do aluno, como se todas fossem iguais com relação a forma, não associando, por exemplo, neurônios e miócitos como células.

Tendo em vista, pela TPC, que aluno aprende na interação com outras pessoas ao escutar o outro e perceber pontos de vista diferenciados, a resposta do aluno foi separada e analisada pelos outros alunos, no momento de escolher o melhor modelo explicativo. Posteriormente nas aulas utilizamos diversos modelos de células enfatizando às diferenças. Atentamos também para célula vegetal, pois eles demonstraram dificuldade em associar estruturas celulares aos vegetais, mesmo já tendo estudado vegetais no ano anterior. $\mathrm{Na}$ intervenção procuramos destacar essas diferenças por meio de imagens, modelos e mesmo na aula prática quando o aluno observou uma lâmina com tecido vegetal de cebola. Utilizamos também modelos de neurônios, células sanguíneas e outras. Outras respostas que apareceram:

$$
\begin{aligned}
& \text { “sim, pois todas as células possuem o mesmo produto dentro” } \\
& \text { “sim, todas as células possuem o mesmo DNA, por isso são iguais”. } \\
& \text { “não, porque os homens têm células diferentes das mulheres” (2 alunos) }
\end{aligned}
$$

Nesse último exemplo, deduzimos que o aluno provavelmente tem noção das diferenças quanto à aparência (características sexuais secundárias), no entanto ele atribuiu as diferenças as células, provavelmente por desconhecer o papel hormonal.

$$
\begin{aligned}
& \text { “as pessoas são diferentes, por isso as células são diferentes". } \\
& \text { "existem células que servem para pele e outras que servem para órgãos", }
\end{aligned}
$$

Percebemos nessa resposta que o aluno tem noção da diferenciação celular e funções, só que envolta em uma linguagem própria. Para Mortimer (2006) "as ideias alternativas das crianças e adolescentes teriam sua origem na linguagem e em outras representações simbólicas disponíveis na cultura cotidiana”. A intervenção precisou considerar essa visão do aluno para apresentar a noção científica.

"cada célula tem uma função e elas precisam se adaptar para exercer tais funções, por exemplo, a hemoglobina é uma célula do sangue, por isso ela não pode ser uma célula da pele”.

A aluna confundiu ou não estava claro ainda no seu arcabouço conceitual, os conceitos de moléculas e células. Ela chama hemoglobina de célula, é fato que somente no primeiro ano 
do EM o aluno estuda célula num grau mais aprofundado em nível molecular. Procuramos dar ênfase que a célula representa a menor porção de matéria viva e é bem mais complexa do que qualquer molécula, enquanto que as moléculas são constituídas por átomos.

A quarta questão- "Dado os termos: DNA, célula, gene, organismo e núcleo. Procure colocar a sequência das estruturas pelo tamanho (partindo do maior para o menor) que você julgar mais correto:" essa foi à questão na qual ocorreram mais erros. O objetivo era mensurar até onde os alunos conseguiam perceber os diferentes níveis propostos, já que é expressiva a confusão que é feita do que seja molécula, átomos, células e até mesmo organismo, no caso dos protozoários e aqueles do Reino moneras. Partimos da perspectiva da DCN (2013, p 161) que afirma que: “A compreensão do real como totalidade exige que se conheçam as partes e as relações entre elas".

Era esperado dificuldades para sequenciar os termos gene e DNA, por eles ainda não terem visto esses conceitos no ensino formal, por isso consideramos satisfatórias as respostas que ordenassem até o nível de núcleo (organismo-célula-núcleo), 16 dos 165 alunos responderam dessa forma, mas tínhamos a perspectiva que alguns alunos já tivessem "ouvido falar" em DNA, gene ou cromossomos e quisemos aferir se eles tinham a noção da localização dessas moléculas, 11 alunos conseguiram a sequência correta, no entanto a maioria absoluta fez grande confusão nas respostas, considerando até mesmo organismo menor que o DNA.

Consideramos a possibilidade dos alunos, cujas respostas estavam completamente corretas, tê-lo feito, pelo fato de termos oferecido os nomes, quando eles teriam apenas que ordenar, ou seja, havia probabilidade de acertos involuntários, por "chute". Conversando posteriormente durante as aulas, essa pergunta foi novamente refeita, só que agora pedindo que os alunos esclarecessem como sabiam das sequências. Os alunos responderam que

a) já conheciam os termos, pois haviam visto em vídeos na internet ou em documentários na televisão.

b) outros falaram que haviam feito extração de DNA usando células vegetais para feira de ciências.

Embora estivéssemos mais preocupados em enfatizar que o conceito de célula está relacionado a sistemas biológicos, como o organismo humano e não ao estudo mais 
aprofundado das biomoléculas, previsto somente para o primeiro ano do EM, aproveitamos a questão para entender a origem da diversidade de respostas e até mesmo o acesso as mídias.

No diálogo ficou implícito que o primeiro grupo de alunos mostrou alguma familiaridade com os termos, sobretudo DNA, provavelmente por estar na mídia. Algumas vezes atrelado à propaganda de cosméticos, de medicamentos, de filmes policiais e até em programas de auditório. A influência dos meios de comunicação na popularização da ciência é incontestável, e a mídia contemporânea vem dando grande ênfase a assuntos ligados à genética molecular e suas várias implicações (biologia reprodutiva, melhoramento genético, transgênicos, clonagem de animais, testes de paternidade, sequenciamento de genomas). No entanto, cabe observar uma tendência, de jornais e de revistas, a apresentar superficialmente informações técnico-científicas, com ênfase nos fatos e acontecimentos de interesse conjuntural, sem compromisso com orientações educativas. Segundo as DCN (BRASIL, 2013):

Apesar da importância que ganham esses novos mecanismos de aquisição de
informações, é importante destacar que informação não pode ser confundida com
conhecimento. O fato dessas novas tecnologias se aproximarem da escola, onde os
alunos, às vezes, chegam com muitas informações, reforça o papel dos professores no
tocante às formas de sistematização dos conteúdos e de estabelecimento de valores. (DCN 2013, p.163).

A quinta questão- "Associe o termo célula a duas palavras:"- nós nos baseamos nos trabalhos de Bastos (1992) que trabalhou com conceitos celulares e usou o método da livre associação de ideias. O objetivo era de que o aluno fizesse alguma associação com organelas ou com partes da célula, como a membrana plasmática ou núcleo. Fizemos uma categorização baseado nas associações mais frequentes que apareceram e estão resumidas na tabela 5, algumas respostas pertenciam a categorias diferentes.

Quadro 5: Respostas dos alunos da quinta questão do questionário

\begin{tabular}{|c|l|c|}
\hline Categorias & \multicolumn{1}{|c|}{ Palavras citadas } & $\begin{array}{c}\text { Quantidade de } \\
\text { alunos }\end{array}$ \\
\hline Microscópica & $\begin{array}{l}\text { Pequeno, menor, invisível, minúscula, micro parte, } \\
\text { partícula. }\end{array}$ & 30 \\
\hline Órgãos ou tecidos & Sangue, pele, pulmão, coração. & 36 \\
\hline Ser humano & Corpo, organismo, humano, ser humano & 26 \\
\hline Vida & $\begin{array}{l}\text { Essencial, saúde, elemento da vida, ser vivo, energia } \\
\text { vital, origem da vida. }\end{array}$ & 13 \\
\hline Moléculas & Gene, cromossomos, DNA, proteínas & 14 \\
\hline
\end{tabular}




\begin{tabular}{|c|l|c|}
\hline Categorias & \multicolumn{1}{|c|}{ Palavras citadas } & $\begin{array}{c}\text { Quantidade de } \\
\text { alunos }\end{array}$ \\
\hline $\begin{array}{c}\text { Constituintes da } \\
\text { célula }\end{array}$ & $\begin{array}{l}\text { Membrana, citoplasma, núcleo, mitocôndrias, } \\
\text { nucléolo. }\end{array}$ & 21 \\
\hline
\end{tabular}

A questão não buscou estabelecer relações entre os termos e sim acessar o imaginário do aluno para conhecer o que ele pensa quando a palavra "célula" foi citada e a partir de aí verificar se aquela palavra exposta tem alguma ligação com o conceito. Categorizamos as palavras mais recorrentes em seis grupos. Na categoria "órgãos e tecidos", por exemplo, verificamos um maior número de palavras que associaram células a algum tipo de tecido. $\mathrm{Na}$ intervenção debatemos com eles que apesar de todas as células apresentarem a mesma informação genética, dado que se formaram a partir do zigoto por mitose, a ordem pela qual se processa a utilização dessa informação difere, conduzindo à especialização.

Bastos (1992) já havia investigado o conceito de célula com alunos do 3o ano do EM, ele utilizou entrevistas que seguiu em grande parte as sugestões de Posner e Gertzog (1982). Uma de suas conclusões foi o caráter antropomórfico das ideias dos alunos ao associar o termo célula a "vida" e "humano". Na nossa pesquisa pudemos perceber, conforme resultados do quadro 4, o mesmo padrão de respostas. Os alunos em nenhum momento atrelaram o termo célula a outros organismos, sejam vegetais, sejam animais de outras espécies. Igualmente como observado nos trabalhos de Bastos (1992), os alunos confundiram célula com o conceito de átomo e molécula ao associar a carbono ou DNA. Associações do termo célula a DNA, gene e cromossomo nos faz conjecturar que as concepções trazidas pelos alunos podem estar influenciadas pela mídia, mas que não necessariamente garante que estejam embasadas por conhecimento científico consistente.

A investigação de perfis de diversos conceitos está descrita na literatura. Por exemplo, Amaral e Mortimer (2001) investigaram o perfil do conceito de calor em química, Santos e Domènech (2005) examinaram o conceito de massa em física, Coutinho, Mortimer e El-Hani (2007) examinaram o perfil conceitual de vida em biologia e Nicolli e Mortimer (2009), o perfil conceitual de morte.

É oportuno esclarecer que o objetivo do presente trabalho não foi de fazer o perfil conceitual sobre célula viva. Mas sim propor uma estratégia de ensino, à luz da TPC, para professores que ensinam no $8^{\circ}$ ano do ensino fundamental, a partir de um levantamento prévio de informações coletadas e analisadas, num contexto de sala de aula dentro de estudos na 
área. Por considerarmos essa teoria como fundamento para nossa estratégia, inferimos que conhecendo as concepções alternativas dos alunos sobre célula viva ficaria mais fácil entendermos os supostos obstáculos que dificultam a sua aprendizagem para uma linguagem científica.

Uma vez explicitadas as ideias dos alunos (presentes nas respostas do pré-teste), elas serviram como base para a proposição das atividades experimentais. Após essas etapas a estratégia de ensino pode ser direcionada objetivando a superação das dificuldades. Por exemplo, nas aulas de CFB do 80 ano, observou-se a confusão que alguns alunos fazem ao não saberem distinguir uma célula animal da vegetal ou de um eucarionte e procarionte, situações já vistas no ano anterior. Para esse trabalho, consideramos utilizar como estratégia o desenvolvimento histórico do conceito de célula e seus significados.

Portanto, nas atividades de sala de aula, uma discussão a respeito desses vários significados foi feita, com o objetivo de evidenciar que existem diferentes formas de compreender célula. Utilizamos, por exemplo, uma aula de microscopia para explorar processos históricos envolvido na formação dos conceitos celulares, além da visualização da célula propriamente dita. Após apresentação da linha histórica e da visão microscópica da célula avançamos para uma ação mais lúdica, como a atividade a seguir:

Passos utilizados:

a) trazer diversas imagens prévias de células, animal e vegetal

b) a seguir, conduzimos a pergunta: $O$ que a célula tem? São apresentados os passos para a montagem de um modelo de célula animal, que depois será transformada em uma célula vegetal.

c) cada aluno foi montando seu modelo de célula, utilizando seu kit de montagem de modelo de célula individual (que é uma versão impressa da internet), onde ele recortou cada organela e estrutura celulares. Conforme cada uma e sua função correspondente foram sendo apresentadas pelo professor, o aluno as recortou de seu kit de montagem de modelo de célula, posicionando, corretamente, cada uma dentro da figura do citoplasma, colorindo e colando posteriormente.

d) começando como uma célula procarionte, avançando para uma eucarionte, todas as organelas e estruturas foram sendo incluídas no citoplasma passo a passo, até a finalização do modelo. 
e) completado o modelo de célula animal, o aluno precisou transformá-lo num modelo de célula vegetal, com a inclusão de cloroplastos e vacúolos no citoplasma e com a célula montada sendo colada dentro da figura que representa a parede celular.

A ideia de propor um perfil conceitual a respeito de célula viva para que os estudantes se utilizem diferentes conjuntos de conceitos, ou "modelos", visando organizar suas concepções referentes à célula, ainda não foi proposto na literatura. Todavia, utilizamos o trabalho realizado por Claudia de Alencar Serra e Sepúlveda da Universidade Federal da Bahia, em sua tese de doutorado a respeito de Perfil Conceitual de Adaptação: Uma ferramenta para a análise de discurso de salas de aula de biologia em contextos de ensino, e os trabalhos de Coutinho, Mortimer e El-Hani (2007) sobre o perfil conceitual de vida em Biologia, para embasar a discussão dos resultados obtidos buscando discutir e categorizar, sempre que possível, as concepções sobre células em termos do perfil.

Os trabalhos de Coutinho, de Mortimer e de El-Hani (2007) buscaram construir um perfil conceitual de "vida", utilizando pelo menos três domínios genéticos: o domínio sociocultural, por meio de uma revisão bibliográfica acerca do conceito de vida e sua história; o ontogenético, por meio da compilação de estudos sobre concepções alternativas de estudantes sobre o conceito de vida; e o microgenético, por meio da coleta de dados empíricos empregando questionários. No presente trabalho não foi possível analisar as concepções alternativas à luz da literatura disponível e mesmo os livros didáticos, devido à ausência de informações. Isso significa dizer que categorias sugeridas estarão associadas aos estudos de Coutinho (2006) e Bastos (1992), fazendo sempre as devidas adequações.

Os estudos de natureza epistemológica e histórica em relação à célula encontrados na literatura também serviram de base para analisar as respostas dos alunos. Para a delimitação do trabalho de coleta de dados, escolhemos as cinco turmas do $8^{\circ}$ ano. Foi ventilada a possibilidade de verificação de coleta de dados em outra série, como o $9^{\text {o }}$ ano do ensino fundamental, mas nessa série não se estuda célula e sim fundamentos introdutórios de química e de física, de acordo com o programa. Os alunos só voltam a ter contato o assunto novamente no ensino médio.

Um aspecto que consideramos importante e que foi percebido durante o desenvolvimento do trabalho foi a heterogeneidade das ideias dos alunos acerca do conceito de célula, evidenciadas tanto no questionário aplicado (pré-teste), quanto nas abordagens durante as aulas. Entendemos que o acesso do professor a essa gama de ideias que os alunos 
trazem em sua bagagem, poderá lhe dar base para se apropriar de alguns recursos didáticos disponíveis e com isso auxiliar os alunos na compreensão desse conteúdo; sempre os levando à construção de conceitos científicos a partir daquilo que eles já trazem, ou seja, por meio dos conceitos espontâneos.

Nem todas as situações são previstas num cenário de sala de aula, mas o fato de analisar os perfis possíveis ajuda muito no planejamento da aula, pois auxilia o professor a preparar os argumentos e contra-argumentos. Não podemos desprezar a capacidade dos alunos de defenderem suas ideias, no entanto, até essa variável pode ser usada para dinamizar a aula.

O aluno chega a escola respondendo que "somos feitos de carne e osso" como apareceu no pré-teste, porque esse é o pensamento do senso comum, essa é a linguagem ouvida no seu cotidiano. A partir daí o professor pode leva-lo a pensar de que é feito essa "carne" e "osso"? será o osso apenas uma estrutura de sustentação da "carne"? ou possui outras funções? É feito apenas de uma estrutura mineralizada ou também possui células? qual a relação entre essas partes e outros tecidos do corpo humano? será que o músculo experimenta certos processos de natureza bioquímica e biofísica, a ponto de se diferenciar de suas características originais, passando a ser considerado "carne"? Segundo a TPC é possível o aluno manter esse pensamento, mas adquirir contornos explicativos mais amplos e usa-los nos momentos oportunos cada um deles.

Giordan e Vecchi (1996) enumeram o que eles chamam de "obstáculos à apropriação do saber", caracterizados como estruturais. Citam por exemplo, as múltiplas reformas do ensino, questiona a falta de unidade e de continuidade, o baixo número de horas dedicadas às ciências e o despreparo do professor, no que tange ao domínio da própria disciplina que leciona e os métodos didáticos disponíveis. Segundo os autores, há profissionais que sequer "ouviram falar da epistemologia das ciências", no entanto, eles também citam os obstáculos epistemológicos que consideram mais delicado, pois nesse caso o ensino científico deixa de levar em consideração o que é o aluno.

Passarei a alinhavar os obstáculos, com relação à apropriação do conceito de célula, percebidos ao longo das aulas durante o semestre:

I) a natureza microscópica da célula;

II) as figuras de células no livro didático (figuras estanques como se todas as células fossem iguais); 
III) assimilações inadequadas ou incompletas, adquiridas até na escola, tais como TODA célula é constituída de Membrana plasmática, citoplasma e núcleo;

IV) dificuldade com o vocabulário técnico.

Com relação ao item II supracitado, o Colégio Militar adota um livro didático específico proposto pelo MEC, que em alguns aspectos estão alinhados com a TPC, como por exemplo, a qualidade dos textos, o embasamento dos conteúdos, os exercícios propostos e reflexões sobre problemas do cotidiano, mas seria necessário um apoio maior quando se trata de imagens de células, algumas comparativas de células animais e vegetais, eucarioto e procarioto e também mais informações históricas, que é a base do segundo eixo da teoria: História e Filosofia da Ciência.

Uma atividade para complementar essa lacuna foi a visualização de vários tipos de células em sites da internet (atividade em casa), onde foi pedido ao aluno que trouxessem figuras de células as mais variadas possíveis, sejam animais (espermatozoides, ovócitos, neurônios, hemácias etc) sejam vegetais e moneras. Durante a aula em grupo eles tentaram agrupar as similaridades e diferenças encontradas, ao final foi feito uma sistematização expositiva com as principais características.

De que forma o professor pode mediar à superação de tais obstáculos? O professor precisa antes de tudo refletir continuamente a respeito de suas práticas de ensino. Paulo Freire (1980) afirma que "o utópico não é o irrealizável" ou seja, é preciso acreditar na mudança, na inovação da forma de ensinar. Uma característica fundamental na postura do professor é a maleabilidade frente às situações que ocorrem durante a aprendizagem, não há respostas prontas, acabadas, mas sim um processo recursivo e contínuo de aprender.

Segundo as DCN (BRASIL,2013 P. 16): “as sociedades abertas não têm os caminhos traçados para um percurso inflexível e estável. Trata-se de enfrentar o acaso, a volatilidade e a imprevisibilidade, e não programas sustentados em certezas". Portanto, é preciso que o professor assuma uma posição de reflexão para mudanças de paradigmas quando for preciso, fomentado tanto pela escola como pela conscientização do próprio professor. O SCMB é um exemplo de Instituição que segue um padrão filosófico, no entanto, é possível uma pluralidade de caminhos mesmo dentro da agenda fixa, sem alterar seu projeto político pedagógico.

Mortimer (2006) aponta como uma alternativa para a superação de obstáculos epistemológicos auxiliar os alunos a reconhecerem similaridades na diversidade aparente, eles podem ser levados a reconhecer características comuns nos modelos aparentemente diferentes que descreveram. O autor também chama a atenção da sala de aula como um espaço de enculturação, onde cabe ao professor explicitar os obstáculos epistemológicos e ontológicos 
que contradizem os conceitos científicos, além de dar oportunidade para que o estudante reflita sobre suas próprias ideias e generalize as novas por si só.

Giordan e Vecchi (1996) apontam o despreparo intelectual dos professores como uma dificuldade em lidar com obstáculos da aprendizagem, tanto no domínio do próprio conteúdo, quanto no atendimento a gerações muito dessemelhantes entre si e mais ainda quando as discussões adentram outras áreas do conhecimento, como humanas e históricas. O DCN (2013) se reporta a esse professor dizendo que é "preciso o adequado domínio dos diferentes saberes disciplinares do campo específico de sua área de conhecimento, para poder fazer escolhas relevantes dos conteúdos”. (DCN 2013, p. 251). Durante toda pesquisa precisei buscar conhecimento a respeito dos aspectos históricos sobre cada conceito celular.

Krasilchik (2004), abordando as diferenças entre professores de biologia e alunos em sala de aula, cita a importância de reduzir as diferenças na compreensão dos códigos e valores peculiares dos dois grupos. Segundo a autora,

a) o uso muito acentuado de questões objetivas do tipo múltipla escolha dificulta para o aluno pensar de forma lógica e coerente e fazer ligações com outros assuntos. A autora defende que as questões que valorizam a exposição de ideias sejam mais utilizadas;

b) a ênfase excessiva a terminologias técnicas, fazendo com que o aluno pense que célula é um conjunto de nomes e substâncias que eles precisam decorar sem, no entanto, fazer sentido para ele. A autora cita que os usos de termos em uma aula de célula saltam em média, de seis para onze novos termos, em detrimento da análise dos próprios processos metabólicos;

c) a falta de interação do professor com o aluno. A autora defende a substituição das aulas expositivas que ocupem muito tempo com preleções por aulas que estimulem a discussão de ideias. Intensificando a participação dos alunos.

Com relação ao tópico "c" supracitado, entendemos que, de acordo com a TPC, é preciso dar mais espaço para o aluno explicitar suas ideias a respeito do conceito de célula mesmo que, por vezes, demonstrem uma visão um pouco frágil em relação ao conceito esperado, utilizando explicações diferentes daquelas que seriam aceitáveis cientificamente. As ideias prévias podem evidenciar pontos importantes de onde estejam as dificuldades. Selecionar as concepções mais frequentes e, a partir desse entendimento, fazer o planejamento pode ser um modo de enfrentar as dificuldades na apreensão dos conceitos científicos e, desse modo, a aula expositiva centrada apenas no professor possa ser transformada em "exposições dialogadas", centradas nos três atores do processo: o aluno como indivíduo, o professor e os alunos como coletivo. 
Analisando os resultados percebemos, por exemplo, a recorrente ideia que células e organismo são entes distintos. Frases do tipo: “Assim como nós, as células vão morrendo" nos sugere que na visão do aluno, "nós" e "células" são dissociados, mas isso só foi possível porque tivemos acesso ao pensamento deles e eles mesmos puderam verificar que compartilhavam ideias parecidas. No planejamento, portanto, precisei aprimorar e enfatizar a escala dos níveis de organização dos seres vivos.

\section{Átomos $\Rightarrow$ Moléculas $\Rightarrow$ Organelas $\Rightarrow$ Cálulas $\Rightarrow$ Tecidos $\Rightarrow$ Órgăos $\Rightarrow$ Sistemas Organismo $\Rightarrow$ Populaçăo $\Rightarrow$ Comunidade $\Rightarrow$ Ecossistema $\Rightarrow$ Blosfera}

Uma atividade que envolva realmente os alunos provoca a busca de novas informações para a resolução ou entendimento de outras situações, a concentração, a cooperação entre colegas e a necessidade de organização. Tem como objetivo dar oportunidade ou mesmo provocar os alunos a organizar o pensamento e expressá-lo oralmente ou graficamente, expor seus conceitos e crenças e confrontá-los com os dos demais colegas e com a argumentação do professor, numa dinâmica proativa.

Outro aspecto importante é a utilização da história e filosofia da ciência como um dos possíveis caminhos para a melhoria do ensino de ciências (MORTIMER, 2006), seja como conteúdo em si, seja como estratégia didática facilitadora da compreensão de conceitos. Matheus (1995) salienta a importância de fazer com que o aluno estabeleça parâmetros entre o passado e presente. Abaixo (quadro 6) um exemplo de uma linha do tempo retirado de um material de apoio da USP, a respeito da evolução dos conhecimentos acumulados da célula e da microscopia. Esse é um modelo geral, na aula utilizei só alguns recortes históricos.

Quadro 6: Linha do Tempo mostrando a evolução dos conceitos de célula

$\underline{1665}$ - Robert Hooke - Publica os primeiros desenhos de células observadas ao microscópio: células mortas de cortiça.

1831 - Robert Brown - Estudando partes das plantas ao microscópio descobre o núcleo das células.

$\underline{1865}$ - Gregor Mendel - Demonstra a existência de elementos individuais e auto-replicáveis, posteriormente chamados de genes, responsáveis pela manifestação das características hereditárias.

1869 - Friedrich Miescher - Encontra uma nova substância orgânica, isolada de núcleos de células de pus humano, denominada nucleína. Vinte anos mais tarde foi chamada de ácido nucléico.

1879 - Walther Flemming - Descreve o comportamento dos cromossomos durante a divisão celular.

1915 - Thomas Morgan - Estabelece a relação entre genes e cromossomos, e formula a teoria cromossômica da 
herança.

1923 - Robert Feulgen - Pelo método de coloração DNA-específico, fortalece a teoria de que os genes estão localizados nos cromossomos.

1929 - Phoebus Levene - Descreve a composição química dos ácidos nucléicos.

1944 - Oswald Avery - Comprova, após alterar a descendência de uma bactéria com o DNA de outra, que esta substância é o material genético, abolindo de vez a tese de que as informações hereditárias estariam guardadas nas proteínas.

1950 - Erwin Chargaff - Verifica que existe uma proporção aproximada de 1:1 entre as bases nitrogenadas adenina (A) e timina $(\mathrm{T})$ e 1:1 entre citosina $(\mathrm{C})$ e guanina $(\mathrm{G})$.

Início da década de 50 - Alexander Todd - Estuda minuciosamente os nucleosídeos (base nitrogenada ligada a um açúcar) e conclui que estes estão ligados a grupos fosfatos das moléculas de desoxirribose, o açúcar do DNA.

1952 - Rosalind Franklin - Descobre, entre outras características, que os grupos fosfatos do DNA estão situados na parte externa da molécula e que esta é formada por cadeias antiparalelas. Estas informações oferecem fortes indícios de qual seria a conformação espacial da estrutura da molécula de DNA.

1953 - Francis Crick e James Watson - Desvendam a estrutura da molécula de DNA, constituída por uma dupla hélice.

$\underline{1977}$ - Frederick Sanger - Elabora uma técnica capaz de determinar a ordem sequencial das bases nitrogenadas do DNA de qualquer organismo vivo.

1983 - Kary Mullis - Idealiza uma técnica experimental que permite obter múltiplas cópias de um fragmento qualquer de DNA.

1985 - Alec Jeffreys - Desenvolve a técnica precursora do teste de paternidade e com a qual é possível identificar cada pessoa por meio do que, segundo o próprio pesquisador, seria um "código de barras" humano.

1996 - Ian Wilmut - Nasce o primeiro clone de um mamífero adulto, a ovelha Dolly, obtido por a partir de uma célula da glândula mamária.

$\underline{2000}$ - Pesquisadores paulistas - Sequenciamento do genoma da bactéria Xylella fastidiosa, causadora da doença do amarelinho em cítricos.

2001 - A empresa Celera Genomics e um consórcio de laboratórios internacionais (Organização do Genoma Humano) - Rascunho do mapeamento do genoma humano, revelando que este é formado por aproximadamente 30 mil genes, e não 100 mil, como era até então estimado.

Fonte: Espaço interativo de Ciências: Disponível em http://cbme.usp.br/index.php/material-de-apoio/145linhadotempo.html. Acesso em 10 mar 2015 
Resultado do Pós-teste

Para Mortimer (2006), é necessário considerar que após a aplicação da instrução, os resultados não poderiam ser analisados apenas a luz das categorias do pré-teste. Ele chama atenção das lacunas apresentadas até mesmo pelos alunos cujos modelos se aproximam muito do esperado para aquele conceito científico em destaque. É de se esperar que o novo conceito faça sentido para os estudantes e desenvolva neles uma forma de conhecimento flexível que possa ser ampliado durante a formação de outros saberes numa constante "rede" de significados.

De um modo geral, ao analisarmos os rendimentos dos alunos do $8^{\circ}$ ano pôde-se perceber um incremento na aprendizagem, tanto em função da análise dos resultados obtidos no pós-teste, bem como a perspectiva de que a abordagem metodológica e recursos de ensino utilizados, para trabalhar os conteúdos curriculares ajudaram na apropriação do conceito de célula.

Não poderíamos deixar de mencionar uma dificuldade que é citada por colegas professores e encontra eco na literatura e que apareceu também na pesquisa- a dificuldade de interpretar textos- no caso específico os questionamentos. Vygotsky (1987, p.86), afirma que a criança “ pode não adquirir novas formas gramaticais ou sintáticas na escola, mas, graças ao aprendizado da gramática e da escrita, realmente torna-se consciente do que está fazendo e aprende a usar as habilidades conscientemente”. Considerando que o ato de interpretar tex to é uma habilidade desenvolvida desde a infância e não acontece de uma hora para outra procuramos minimizar o problema fazendo algumas recomendações, tais como: leia as perguntas, procurando ter uma visão geral do assunto; se encontrar palavras desconhecidas, não interrompa a leitura; leia as perguntas pelo menos duas vezes; verifique, com atenção e cuidado o enunciado de cada questão.

O primeiro questionamento proposto continha a seguinte pergunta: 1)Tanto os organismos unicelulares como as células dos vários tecidos dos pluricelulares são muito diferentes entre si. Apesar dessa enorme variedade, quais os três componentes básicos da maioria das células animais eucariontes? Separamos as respostas conforme o quadro 7 abaixo: 
Quadro 7- Respostas dos alunos a primeira questão do pós-teste

\begin{tabular}{|c|c|c|}
\hline Categorias & Respostas & Percentual (\%) \\
\hline Não responderam & 7 & 5,30 \\
Resposta incompletas & 10 & 7,57 \\
Erradas & 12 & 9,09 \\
Corretas & 103 & 78,03 \\
\hline
\end{tabular}

Esperávamos que os estudantes discorressem sobre as três partes básicas da célula eucarionte (Membrana plasmática, citoplasma e núcleo), lembrando que já havíamos limitado o objeto de estudo, focando no conteúdo do $8^{\circ}$ ano (corpo humano). Foram listadas como "incompletas" todas aquelas que consideraram apenas um ou dois dos três componentes. As consideradas "incorretas" foram aquelas que apontaram parede celular na célula animal

Percebendo que a dificuldade pudesse estar na nomenclatura ao confundir parede celular com membrana plasmática, novamente "decompomos" a célula eucarionte, só que dessa vez dedique mais tempo para explorar a grafia correta de cada parte da célula. E comparei uma célula animal com uma célula vegetal. Por meio de perguntas com respostas imediatas do tipo: Cite uma diferença entre os dois modelos a frente? O aluno respondeu que a célula vegetal tinha parede celular e membrana plasmática, enquanto a animal não tinha parede celular.

Durante as aulas além de trabalharmos com os níveis de organização dos seres vivos, levamos modelos celulares para que eles percebessem a correlação espacial entre organelas, DNA e cromossomos, pois havia sido mencionado no pré-teste quando pedíamos o sequenciamento dos termos.

$\mathrm{Na}$ intervenção precisamos tratar da natureza química e invisível do DNA e paralelamente procuramos dialogar a respeito dos pontos mais importantes que pavimentaram a formação histórica do seu conceito até o momento. Mesmo assim, após a intervenção alguns alunos $(9,09 \%)$ não estabeleceram uma relação correta, ainda considerando DNA como uma organela citoplasmática, o que pode sugerir que estes alunos se valeram de respostas memorizadas nas avaliações formais do CMB ainda no primeiro bimestre e que exteriorizaram o erro no pós-teste. Aqui cabe uma reflexão sobre a necessidade de pensar numa abordagem complementar a fim de chegar a esses alunos, ao aplicar a metodologia futuramente. 
O segundo questionamento foi assim descrito: 2) A palavra célula foi usada pela primeira vez em 1665, pelo cientista inglês Robert Hooke. Com um microscópio muito simples, ele observou pedacinhos de cortiça. Hooke percebeu que a cortiça era formada por numerosos compartimentos vazios. O termo célula (do latim Cellula = compartimento vazio) foi introduzido na linguagem científica a partir da observação de material vegetal morto em microscópio rudimentar. Agora, suponha que Robert Hooke tivesse observado células vivas ao microscópio, e não células mortas de cortiça. Baseado nos seus conhecimentos sobre estrutura celular atual, o nome célula seria o mais adequado? Por quê?

O objetivo era fazer uma triangulação entre a História da Ciência, incluindo a microscopia, já que foi muito recorrente na aula e os conceitos celulares atuais discutidos em sala, seja célula morta/viva e animal/vegetal, tentando perceber a tomada de posição do aluno frente a essas questões. Obtivemos os seguintes resultados:

Quadro8: Respostas dos alunos a segunda questão do pós-teste

\begin{tabular}{|l|l|l|}
\hline Categorias & Respostas & Percentual (\%) \\
\hline Erradas & 9 & 6,8 \\
\hline Com erros conceituais & 12 & 9,0 \\
\hline Não responderam & 9 & 6,8 \\
\hline Corretas & 102 & 77,3 \\
\hline
\end{tabular}

Nessa questão observamos que a maior parte dos alunos conseguiu expressar suas ideias acerca da estrutura celular (77,3\%), suas organelas, além das limitações do instrumento de medida da época e outros. Os alunos explicitaram nas respostas que os Eucariontes (com envoltório nuclear) apresentam uma organização mais complexa com estruturas chamadas de organelas, bem diferentes do que Hooke havia observado no passado, "pois ele não tinha um microscópio tão bom", por isso não poderia ser chamado de célula.

Observamos ainda a dificuldade persistente dos alunos com a linguagem científica. Frases tais como: "o nome está incorreto, pois dentro da célula há várias coisinhas" ou " a célula não é um ser vazio, pois dentro dela tem algo nesse espaço que fazem coisas" (grifo da autora); percebemos que o aluno nesse caso, ampliou seu arcabouço conceitual ao reconhecer que há partes na célula responsável pela produção de energia e pela síntese de proteínas, mas continuaram chamando as organelas de "coisas", "algo" e até "seres". Aferimos uma 
resistência das concepções que ele tinha antes da intervenção e que permaneceu, no que se refere ao uso da linguagem científica, o aluno permaneceu com a linguagem do senso comum.

Assim como fizemos o glossário de termos técnicos no início do ano, a princípio com palavras mais gerais (procarionte, eucarionte, unicelular, pluricelular) aumentamos o alcance para palavras do universo intracelular (mitocôndrias, retículos endoplasmáticos, centríolos, ribossomos)

O terceiro problema: $O$ encéfalo humano é um dos órgãos que apresenta maior irrigação sanguínea. Isto está relacionado ao fato de suas células demandarem grande quantidade de energia. Explique de que maneira o grande volume de sangue contribui para a produção de energia nas células do encéfalo humano?

Essa questão buscou avaliar, dentro da perspectiva da TPC, alguma evidência do alcance de generalização do aluno, pois sendo uma questão feita já ao final do ano letivo, esperávamos que o aluno explicitasse noções de órgãos (encéfalo), tecidos (sanguíneo) e metabolismo energético. “...propriedades essenciais ou sistêmicas (todo) não se encontram nas partes isoladas, só no conjunto, surgem das relações de organização" (CAPRA, 1996, p.46). Queríamos aferir algum potencial de visão sistêmica. O resultado ficou evidenciado no quadro 9:

Quadro 9: Respostas dos alunos a terceira questão do pós-teste

\begin{tabular}{|c|c|c|c|c|}
\hline \multicolumn{2}{|c|}{ Categorias } & Respostas & Exemplos & Percentual $(\%)$ \\
\hline \multirow[t]{2}{*}{ Corretas } & Complexas & 32 & $\begin{array}{l}\text { "o encéfalo é uma região importante que } \\
\text { necessita de grande quantidade de glicose } \\
\text { e oxigênio trazidos pelo sangue" } \\
\text { "as hemácias do sangue transportam } \\
\text { oxigênio e o plasma transporta nutrientes } \\
\text { necessários para produção de energia no } \\
\text { encéfalo" }\end{array}$ & 42,0 \\
\hline & Simples & 68 & "o sangue é um tecido transportador" & 21,8 \\
\hline \multicolumn{2}{|c|}{ Não responderam } & 23 & XXXXX & 17,4 \\
\hline \multicolumn{2}{|c|}{$\begin{array}{l}\text { Erradas ou sem } \\
\text { entendimento }\end{array}$} & 9 & $\begin{array}{l}\text { "devido à grande quantidade de } \\
\text { mitocôndrias soltas no sangue" }\end{array}$ & 6,8 \\
\hline
\end{tabular}

Subdividimos a categoria correta em "complexa" e "simples", por consideramos que algumas respostas demonstravam um nível de generalização maior, com uma visão mais 
sistêmica do corpo humano (complexas) levamos em consideração as respostas que, utilizando-se de vários campos do conhecimento a respeito do corpo, conseguiram integrá-los e sintetizá-los. Já outras (as simples) traziam maior objetividade, mas estavam igualmente corretas.

A quarta e última questão do pós-teste: Defina com suas palavras, a partir dos conhecimentos adquiridos, o que é célula? Buscamos uma resposta com caráter mais direto no que diz respeito a Teoria celular. Esperávamos que o aluno respondesse que a célula é a menor parte dos seres vivos com formas e funções definidas. O resultado foi compilado no quadro 10 abaixo:

Quadro 10: Resultado das respostas dos alunos a questão 4 do pós-teste

\begin{tabular}{|l|c|c|}
\hline \multicolumn{1}{|c|}{ Categorias } & Respostas & Percentual (\%) \\
\hline Não sabiam ou em Branco & 8 & 6,0 \\
\hline $\begin{array}{l}\text { Erradas ou com falhas } \\
\text { conceituais }\end{array}$ & 28 & 21,2 \\
\hline Corretas & 96 & 72,7 \\
\hline
\end{tabular}

Todo trabalho foi feito considerando a TPC e como tal não foi possível observar a evolução das ideias do aluno individualmente, mas a consequência da interação social entre vários indivíduos no mesmo grupo ou com a sala inteira. (MORTIMER, 2006, p.193)

Analisando a evolução conceitual dos alunos, verificamos que o primeiro dado que chamou a atenção foi a definição espontânea de célula como um "ser", ou "microrganismo". No pré-teste essas definições estavam mais presentes. Muitos alunos consideravam a célula como anexo ao corpo humano e não como parte dele. É possível que o motivo para este fato seja que a informação da importância vital da célula estivesse desassociada do conceito de que a célula, por excelência, é a unidade formadora de todos os seres vivos.No pós-teste os alunos se posicionaram com mais clareza quanto a natureza da célula. Na última questão do pós-teste $72,7 \%$ já externaram que célula é a menor parte que compõe o ser vivo.

Mortimer (2006) chama a atenção que o abandono de uma visão para outra, por vezes acontece pela argumentação racional, a autoridade do professor e a pressão social do grupo em favor das ideias científicas. Mas é possível que o aluno permaneça com as mesmas visões anteriores as instruções, mas naquele momento não as exteriorize para não enfrentarem a 
"pressão social". O que não quer dizer que em outro momento, individualmente, ele não o faça.

Ao longo da pesquisa percebemos que precisamos trabalhar os conceitos científicos, sem desconsiderar os conceitos alternativos dos alunos. É através da interação dos dois conceitos (científico e espontâneo) que se dá à evolução real do pensamento. Entender os conceitos prévios dos alunos possibilita que estes, por meio da reflexão e da atividade, propiciem a interação com o conceito construído cientificamente.

Ao final do ano letivo busquei verificar o feedback da aplicação da metodologia, perguntando aos alunos se eles gostaram de trabalhar da forma prevista no TPC. As respostas apontaram que sim. Foram citados por eles como "muito bom" a linha do tempo, a aula em que montaram a célula, a aula prática do laboratório e as discussões nos grupos. Considerando também que uma particularidade prevista nos eixos de sustentação da teoria preconiza uma "mudança na própria visão do professor de enxergar o conceito" posso atestar na prática que essa premissa é verdadeira. Uma experiência construída em parceria com os alunos, na qual ambos foram coautores da aprendizagem. 


\section{CONSIDERAÇÕES FINAIS}

Para a construção de conceitos relacionados à célula, os alunos por vezes, recorrerem a algum modo de abstração e de relação com outras informações, como átomo, molécula, fotossíntese, respiração, síntese de proteínas, multiplicação celular, entre outras. Várias informações permeiam o imaginário, algumas vezes eivados de concepções do senso comum. Nem sempre é fácil fazer essas correlações, já que a célula é invisível, muito menos enxergar que o "invisível" faça parte do todo visível: o corpo humano, no entanto, baseados nos resultados obtidos, por meios de observações em aula, avaliações formais ao longo dos bimestres e o pós-teste, pudemos concluir que a metodologia aplicada atingiu a maioria dos alunos no que diz respeito à ampliação do arcabouço conceitual. Embora reconheçamos que muitas dúvidas permaneceram e que são necessárias mais situações práticas de aprendizagem objetivando melhorar cada vez mais o entendimento da aplicação da metodologia presente na TPC.

À medida que a pesquisa foi se desenvolvendo, verificamos que a nossa percepção dos conceitos também ia mudando, não apenas pelas novas informações que iam se incorporando, mas pelas reflexões históricas, políticas e filosóficas que nos eram confrontadas. Percebemos, por exemplo, a grande correlação entre os avanços dos conhecimentos da célula e a evolução da tecnologia, sobretudo a microscopia e foi por meio dele que a ciência começou a revelar à humanidade o mundo minúsculo das células e dos microrganismos. Os estudos continuaram e os microscópios foram sendo gradativamente aperfeiçoados. Com isso, obtiveram-se imagens cada vez mais nítidas do mundo microscópico, que permitiram observações e descrições mais rigorosas até os dias atuais.

Também pudemos verificar que quando utilizamos exemplos ou situações que fazem parte do cotidiano, os alunos conseguem se inserir e compreender melhor os conceitos trabalhados. Sendo assim, fez-se necessário utilizarmos uma metodologia prática como a TPC, na qual a interação professor-aluno, alunos-alunos é fundamental.

Seria ingênuo pensar que qualquer mudança estrutural seja simples, há sempre resistências, medos, inexperiências, mas é salutar buscarmos propostas de aulas diferenciadas. A TPC não propõe rupturas e pode tranquilamente coexistir com as propostas de ensino do Exército Brasileiro e de outras Instituições de Ensino e somar ainda mais na perspectiva de melhoria da aprendizagem dos estudantes e de nossas próprias práticas pedagógicas. 
O grande diferencial da Teoria do Perfil Conceitual é enfatizar que o indivíduo não necessariamente muda conceitos, mas adquire novos conceitos. Mesmo dentro da visão científica escolhemos os melhores modelos para explicar um fenômeno ou resolver problemas, mas no cotidiano não abandonamos nossas concepções de senso comum. Portanto, como professores não podemos esperar que os alunos utilizem aquele novo conceito em todas as situações da vida, se nós mesmos não fazemos. O importante é que no momento oportuno ele saiba usar.

Obviamente foi um desafio por ser algo novo na minha prática profissional, na qual o tempo e a agenda dos demais conteúdos exerciam pressão o tempo todo, não obstante, os trabalhos em equipe, as discussões e as explicitações das ideias alternativas ocuparam lugar de destaque, a busca pelo olhar sistêmico também pôde ser testada durante o ano: a célula como fundamento para entender o corpo humano, o homem como ser social e ambiental interagindo com outras espécies, cujas células com suas especificidades constituem também seus corpos.

Trabalhamos com alguns fatores que contribuíram diretamente para a nossa conscientização e compreensão das dificuldades apresentada pelos alunos na apreensão do conceito de célula viva, a partir da perspectiva da TPC, além dos trabalhos de DRIVER (1999) e de observações pessoais. Entre esses fatores destacamos: a não valorização das ideias do senso comum por muitos professores, ou seja, a consciência que eles são esquemas interpretativos dos fenômenos, por isso não podem ser relegados a um segundo plano; o desconhecimento da natureza do conhecimento científico, que é simbólico e socialmente negociado; a importância que o ensino da célula tem como uma unidade relevante na biologia, a qual tem suas raízes na própria história da ciência; a aprendizagem de conceitos celulares pautada na fragmentação de conteúdos, sem uma visão sistêmica, entre outros.

Fazendo algumas reflexões após a finalização da pesquisa e na busca pelo aprimoramento do processo, algumas atitudes didáticas eu redefiniria para próximos trabalhos, entre elas destaco o período em que foi aplicado o pós-teste. Como foi aplicado no quarto bimestre, devido a meu entendimento de que teria mais tempo para intervenção, não consegui aferir com mais acuidade a evolução das ideias dos alunos, embora tenha utilizado outros instrumentos formais de avaliação do CMB e as observações pessoais. Assim aplicaria o pós-teste para o final do segundo bimestre.

Outra atitude seria diminuir o número de conceitos avaliados, fixando-me mais na teoria celular, a fim de me aprofundar um pouco mais na evolução do pensamento do aluno, 
primeiro pela limitação do tempo letivo e também pelo currículo impositivo, ao qual estou subordinada.

Com relação aos recursos utilizados na intervenção, entendemos que a avaliação mais precisa dos materiais didáticos deva ser feita pelo aluno, público a quem são destinados. $\mathrm{O}$ aluno durante o processo de aprendizagem consegue diagnosticar de maneira mais legítima as dificuldades de uso; todavia dialogando com os alunos a respeito dos recursos e da maneira como foram conduzidos os trabalhos, eles afirmaram que gostaram do formato de trabalhar em grupo e participar das decisões de escolher do melhor modelo, além da aula prática, da história da célula, das imagens e outros.

Não obstante, minha leitura é que os resultados poderiam ser melhores se fossem mudadas algumas sequências de aplicação, como por exemplo, o glossário, aplicando-o desde o início da intervenção. O glossário auxiliou à medida que usamos termos cujo significado não era ambíguo, familiarizou os termos, indicou as propriedades definidoras e não demandou tempo em sala, já que era uma atividade extraclasse.

À medida que íamos caminhando em nossa pesquisa, as discussões provocadas pela análise dos dados coletados revelavam limite de tempo, pois os estudantes demonstraram grande interesse e envolvimento nas atividades realizadas quando explorávamos a história das descobertas celulares, trazendo-nos surpresa na eficiência desse recurso. Possivelmente se tivéssemos mais tempo para explorar a História da Ciência e nos aprofundássemos nela, obteríamos melhores resultados.

Chamou-nos a atenção que certos padrões de fala dos alunos antes ou durante a instrução caracterizaram-se pela interação de múltiplas vozes. Mas, no decorrer do processo a maioria dos alunos foi se apropriando da voz do professor, se apropriando da linguagem científica e internalizando-a (MORTIMER, 2006, p. 258). A sala de aula pôde ser vista como um espaço de enculturação, sendo o professor o agente que dar oportunidades ao estudante de refletir sobre suas ideias e compará-las com as ideias científicas.

Nesse sentido, acreditamos que um Módulo Didático para professores do $8^{\circ}$ ano pode contribuir para melhorar o Ensino de Ciências nos anos iniciais do Ensino Fundamental. Sendo assim, a nossa intenção com a proposta de intervenção que será apresentada a seguir, além da respectiva contribuição, é a de que sua leitura e aplicação possa ser ressignificada sempre, pois o ensino precisa ser visto como algo dinâmico e em constante construção. 


\section{BIBLIOGRAFIA}

AUSUBEL, D.; NOVAK, J. D.; HANESIAN, H. Psicologia educacional. Rio de Janeiro: Interamericana, 1980.

AMABIS, J.M; MARTHO,G.R-Biologia das Células. São Paulo, Editora Moderna, 1999.

ALMEIDA, M. da C. de. Uma Ciência perto da natureza. In: ALMEIDA, Maria da Conceição de \& PEREIRA, Wani Fernandes (Orgs). Lagoa do Piató: fragmentos de uma história. $2^{\mathrm{a}}$ ed., revista e ampliada. Natal-RN: 2006.

ALBERTS, B.; Johnson, Alexander; Lewis, Julian; Raff, Martin; Roberts, Keith; Walter, Peter. Biologia Molecular da Célula. 5 ed. Porto Alegre: Artmed, 2011.

ALBERTS, B. Biologia Molecular da Célula. 3 ed. Porto Alegre: Artes Médicas, 1997

BALL, D., THAMES, M., \& PHELPs, G. Content Knowledge for Teaching: What Makes It Special? Journal of Teacher Education, p. 34, 2008

BASTOS, F. (1992). O conceito de célula viva entre os alunos de segundo grau. Em Aberto, ano11, número 55, 63-69.

BACHELARD, G. La Philosophie du Non, PUF, Paris, 1940 (trad.: A Filosofia do Não: Filosofia do Novo Espírito Científico, Lisboa: Presença, 1991).

BAKHTIN, Mikhail. Questões de literatura e estética. São Paulo: HUCITEC, 1988.

FARACO, Carlos Emílio; MOURA, Francisco Marto. Literatura Brasileira. 15 ed. rev. ampl. São Paulo: Ática, 1998.

BORBA, F.S. Introdução aos estudos linguísticos. 11 ed. Campinas: Pontes, 1991.

BRASIL. Diretrizes Curriculares Nacionais Gerais da Educação Básica / Ministério da Educação. Secretaria de Educação Básica. Diretoria de Currículos e Educação Integral. Brasília, DF, 2013.

CAPRA, F. A teia da vida: uma nova compreensão científica dos sistemas vivos. São Paulo: Pensamento; CULTRIX, 1996.

COUTINHO, F.A; EL-HANI,C.N.; MORTIMER.E.F. Construção De Um Perfil Para O Conceito Biológico De Vida- Investigações em Ensino de Ciências - V12(1), pp.115-137, 2007

COUTINHO, F. A. Construção de um perfil conceitual de vida. Belo Horizonte: Faculdade de Educação da UFMG. (Tese de Doutorado), 2005.

COLL, C. et al. O construtivismo na sala de aula. São Paulo Ática, 2006.

DRIVE, R;ASOKO, H;LEACH, J; MORTIMER, E.F; SCOTT,P. Construindo conhecimento científico em sala de aula- química Nova na escola n ${ }^{\circ}$ 9, maio 1999.

Do LED azul ao GPS cerebral-Edição de 2014 do Prêmio Nobel destaca avanços em microscopia,neurociência e óptica:Disponívelem:http://revistapesquisa.fapesp.br/2014/11/18/led-azul-ao-gps-cerebra. Acesso em 15 Fev 2015 
DRUZIAN, A.; BRÜCKMANN, IADES A.; SANTOS, R. P. dos. Construção de um Teste através de um Inventário do Conceito de Energia. in: Atas do V ENPEC - Encontro Nacional de Pesquisa em Ensino de Ciências, Bauru/SP, ABRAPEC, 28 de Outubro a 2 de Dezembro de 2005, Bauru: Associação Brasileira de Pesquisa em Ensino de Ciências - ABRAPEC, 2005. Disponível em: http://www.fisica-interessante.com/teste-de-energia.html

EL - HANI, C. N.; BIZZO, N. M. V. Formas de construtivismo: mudança conceitual e construtivismo contextual. In: Encontro De Pesquisa Em Educação Em Ciências, 3, 1999, Valinhos - SP. Anais... São Paulo: ABRAPEC, 1999, p. 1-25.

EL-HANI, C. N. Notas sobre o ensino de história e filosofia da ciência na educação científica de nível superior. In: Estudos de história e filosofia das ciências: subsídios para aplicação no ensino. São Paulo: Editora Livraria da Física, 2006.

FOUREZ,G. A construção das ciências: Introdução à Filosofia e a Ética das Ciências. São Paulo: Editora da Universidade de São Paulo, 1995.

GALUCH, M. T. B. e SFORNI, M. S. F. Aprendizagem conceitual nas séries inicias do ensino fundamental. In II Segundo Congresso Internacional e VII Semana de Psicologia Psicologia: Sociedade e Saberes em transformação, 2005, Maringá. ANAIS - II Segundo Congresso Internacional e VII Semana de Psicologia -

GIORDAN, A.; VECCHI, G. de (1996). As origens do saber: das concepções dos aprendentes aos conceitos científicos. 2. ed. Porto Alegre: Artes Médicas.

GOWDAK, D. M. E.-. Ciência: novo pensar / Corpo Humano, $8^{\mathrm{a}}$ Série, -- $2^{\mathrm{a}}$ ed., renovadaSão Paulo, FTD, 2009.

GOULART, M. S. História da Ciência: Elo da dimensão transdisciplinar no processo de formação de professores de Ciências. LIBANEO, J.C \& Santos, AKIKO (org.). Campinas, SP: Alínea, 2005.

HENTZ, P. Eixos norteadores da proposta curricular. In: Proposta curricular de Santa Catarina: educação infantil, ensino fundamental e médio: temas multidisciplinares. Florianópolis: COGEN, 1998.

KRASILCHIK, M. Prática de ensino de Biologia. 2. ed. São Paulo Harper \& Row, 1986. 195p.

KRASILCHIK, M. Prática de ensino de biologia. São Paulo: Editora da Universidade de São Paulo, 2004.

LAVILLE, C.; DIONNE, J. A construção do saber: manual de metodologia da pesquisa em ciências humanas, tradução H. Monteiro e F. Settineri. Porto Alegre: Artmed; Belo Horizonte: Editora UFMG, 1999, p.342.

LEWONTIN, R. (2002) A tripla hélice. São Paulo: Companhia das Letras.

LaBiSisMi. Biologia Sistêmica. Disponível em: http://labisismi.fmrp.usp.br/index.php/br/ . Acesso em: 9 ago. 2014

MARTINS, J.S. O senso comum e a vida cotidiana. Tempo Social; Rev. Sociol. USP, S. Paulo, 10(1): 1-8, maio de 1998.

MACHADO, C. G.. Multiculturalismo: muito além da riqueza e da diferença. Rio de Janeiro: DP\&A, 2002. 
MATTHEWS, M. Construtivismo E O Ensino De Ciências: Uma Avaliação Cad.Cat.Ens.Fís., v.17, n.3: p.270-294, dez.2000.

MEADOWS, A. J. A comunicação científica. Brasília: Briquet de Lemos, 1999.

MINAYO, M.C.S. (org.). Pesquisa Social, Teoria, Método e Criatividade. Petrópolis: Vozes, 1994

MOSLEI, M., LYNCH, J. Uma História da Ciência. Rio de Janeiro; ZAHAR, 2010.

MONTAIGNE, M. Ensaios. São Paulo: Abril Cultural, 1972. (Os pensadores).

MORTIMER, E. F. Linguagem e formação de conceitos no Ensino de Ciências. Belo Horizonte: Editora UFMG, 2006.

MORTIMER, E.F. Para além das fronteiras da química: relações entre filosofia, psicologia e ensino de química. Química Nova, 20 (2), 200-207, 1997.

MORTIMER, E. F. Evolução do atomismo em sala de aula: mudança de perfis conceituais. São Paulo, Faculdade de Educação da USP. (Tese, Doutorado), 1994.

MORTIMER, E. F. \& EL-HANI, C.N. Multicultural education, pragmatism and the goals of Science Education. Cultural Studies of Science Education, 2, 657-702, 2007.

MURTA, M.M- Transição Do Vitalismo Para A Visão De Mundo Mecanicista: Contribuições Para O Perfil Conceitual Do Átomo - IX Encontro Nacional De Pesquisa Em Educação Em Ciências, 2014.

OLIVEIRA, S. S. Concepções alternativas e ensino de biologia: como utilizar estratégias diferenciadas na formação inicial de licenciados. Curitiba: UFPR. Educar, n. 26, p. 233-250, 2005

PACCA, J.L.A. \& VILLANI, A.; Um curso de actualización y cambios conceptuales en professores de Física. Enseñanza de las Ciencias; 1996.

PALMERO, R.L. M.; MOREIRA, A M. (2002). Modelos Mentales VS esquemas de células. Investigações em Ensino de Ciências.

PALMER, F. R. A semântica. Tradução de Ana Maria M. Chaves. Lisboa: Edições 70, 1979.

PILETTI,C, Didática Geral-São Paulo. Editora Ática, 1997.

PLANO DE SEQUÊNCIAS DIDÁTICAS - Ministério da Defesa. Departamento De Educação e Cultura do Exercito, $8^{\circ}$ ano / Ensino Fundamental Área: Ciências da Natureza e suas Tecnologias-2014.

PRESTES, M. E. B.Teoria celular: de Hooke a Schwann São Paulo - SP :Scipione, 1ª Ed, 72 p. 1997

PSICOLOGIA: Sociedade e Saberes em transformação. Maringá: Universidade Estadual de Maringá, v.1, p.1-12, 2005.

SEPULVEDA, C. Perfil conceitual de adaptação: uma ferramenta para análise de discurso de salas de aula de biologia em contextos de ensino de evolução. Tese (Doutorado em Ensino, Filosofia e História das Ciências). Universidade Federal da Bahia, 2010.

STF libera pesquisas com células-tronco embrionárias humanas. Disponível em: http://www.stf.jus.br/portal/cms/verNoticiaDetalhe.asp?idConteudo=89917. Acesso em: 05 out 2014 
VYGOTSKY, L. S. Pensamento e linguagem. edição eletrônica. ed. Ridendo Gastgat Moraes. Ebook, set 2001.

VYGOTSKY, L.S. Pensamento e linguagem.São Paulo: Martins Fontes,1987

VYGOTSKY, L. S. Pensamento e linguagem. São Paulo: Martins Fontes, 1993. 
APÊNDICES 
Apêndice 1-Termo de Consentimento Livre e Esclarecido

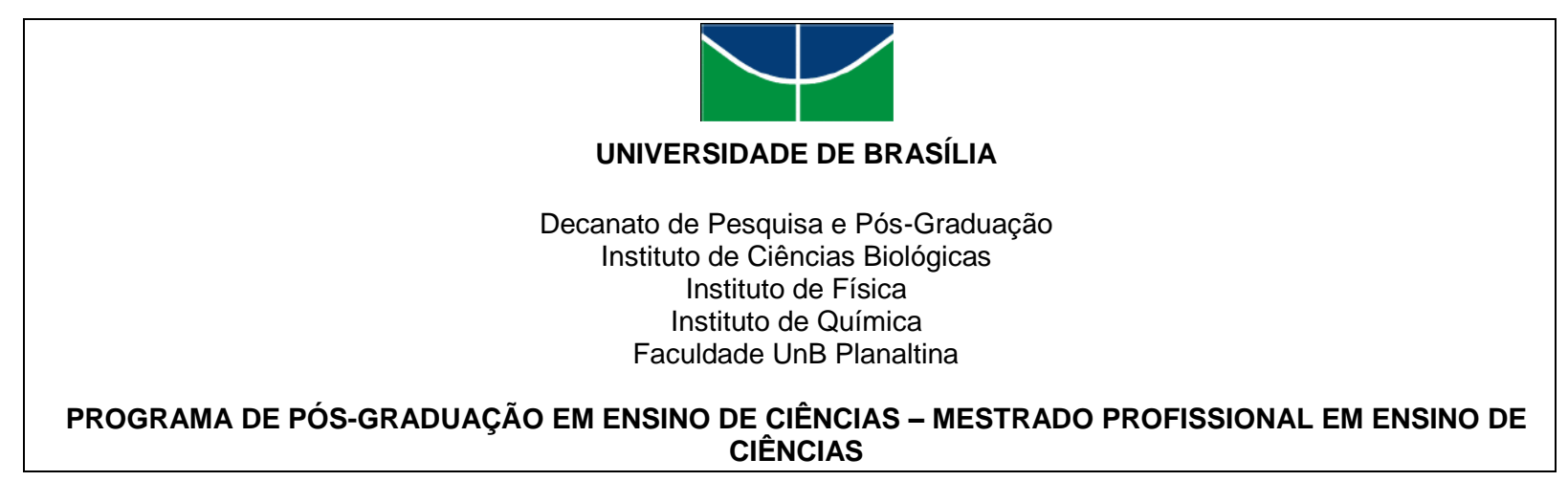

TERMO DE CONSENTIMENTO LIVRE E ESCLARECIDO - TCLE

Caro responsável, seu(sua) filho(a) está sendo convidado(a) a participar, como voluntário(a), em uma pesquisa desenvolvida no âmbito do Curso de Mestrado Profissional em Ensino de Ciências do Programa de Pós-Graduação em Ensino de Ciências da UnB intitulada "Ensino-aprendizagem do conceito de "célula viva": Proposta de estratégia para o Ensino Fundamental". Por meio da aplicação de um questionário a respeito de conceitos celulares. Como nossa pesquisa é colaborativa, queremos construir com o aluno(a) uma parceria, interagindo na busca de alternativas para os diferentes contextos de ensino.

É importante frisar que a participação dele(a) será protegida por total anonimato, quando do registro na futura Dissertação de Mestrado, em todas as suas etapas e em divulgações futuras, por qualquer meio.

Para formalizar a aceitação de seu filho(a) em fazer parte dessa investigação, o que nos deixará honrados, assine, por favor, ao final deste documento, que terá duas vias. Uma delas ficará em seu poder e a outra com a pesquisadoraresponsável.

\section{INFORMAÇÕES SOBRE A PESQUISA:}

Título: "Ensino-aprendizagem do conceito de "célula viva": Proposta de estratégia para o Ensino Fundamental". Pesquisadora-responsável: Jacqueline Alves Araújo França

Contato: amorabio@bol.com.br

Orientador: Maria Márcia Murta

Nosso trabalho visa a contribuir para o desenvolvimento de estratégias de ensino-aprendizagem fundamentadas na perspectiva de compreensão de conceitos celulares fundamentais pelos alunos. Assim, serão coletadas informações por meio de questionários, para análises posteriores, e ficará desde já garantido o anonimato individual dos participantes.

\section{CONSENTIMENTO DA PARTICIPAÇÃO}

$\mathrm{Eu}$,

portador do RG e do CPF abaixo-assinado, autorizo a participação do aluno(a) na pesquisa acima mencionada. Fui devidamente informado e esclarecido pela pesquisadora-responsável, Jacqueline A França sobre a investigação, bem como sobre os procedimentos a serem seguidos, ressaltando-se a garantia plena do anonimato em todos os registros atinentes e em toda a produção acadêmica resultante.

Brasília - DF, 


\section{Apêndice 2- Questionário para os alunos}

Pré-teste

Nome:

$\mathrm{N}^{\mathrm{o}}$ :

.Turma:

Caro aluno, neste questionário, apresentamos cinco questões discursivas. Leia-as e elabore respostas para o que se pede. Não se preocupe com o gabarito. A intenção é convidar você a demonstrar seu conhecimento a respeito do assunto e tentar entender qual a sua visão acerca dele. Portanto, não se preocupe em como vai expressar. Pois você poderá escrever, desenhar, esquematizar etc.

1) Biologicamente, do que você acha que somos feitos?

2) Você acha que todos os seres vivos têm o mesmo número de células? Justifique

3) Você acha que as células são todas iguais? Justifique

4) Dados os termos: organismo, célula, núcleo, gene e DNA. Coloque-os em ordem, de modo a formar a sequência das estruturas pelo tamanho (partindo do maior para o menor) que julgar mais correto:

5) Associe o termo célula a duas palavras: 


\section{Apêndice 3- Questionário para os alunos}

\section{Pós-teste}

Nome: $\mathbf{N}^{\mathbf{0}}:$ Turma:

Caro aluno!

Chegamos ao fim do ano, várias informações acerca do nosso corpo foram discutidas em aula. Entre elas, as células do nosso corpo. Muitas curiosidades, relatos, histórias e informações científicas pautaram nossos debates. Nesse momento, gostaria de saber, a partir, de todo estudo feito ao longo do ano, como você responderia as seguintes questões:

1) Tanto os organismos unicelulares como as células dos vários tecidos dos pluricelulares são muito diferentes entre si. Apesar dessa enorme variedade, quais os três componentes básicos da maioria das células animais eucariontes?

2) A palavra célula foi usada pela primeira vez em 1665, pelo cientista inglês Robert Hooke.Com um microscópio muito simples, ele observou pedacinhos de cortiça. Hooke percebeu que a cortiça era formada por numerosos compartimentos vazios. O termo célula (do latim Cellula $=$ compartimento vazio) foi introduzido na linguagem científica a partir da observação de material vegetal morto em microscópio rudimentar. Agora, suponha que Robert Hooke tivesse observado células vivas ao microscópio, e não células mortas de cortiça. Baseado nos seus conhecimentos sobre estrutura celular atual, o nome célula seria o mais adequado? Por quê?

3) O encéfalo humano é um dos órgãos que apresentam maior irrigação sanguínea. Isto está relacionado ao fato de suas células demandarem grande quantidade de energia. Explique de que maneira o grande volume de sangue contribui para a produção de energia nas células do encéfalo humano?

4) Defina com suas palavras, a partir dos conhecimentos adquiridos, o que é célula? 
Apêndice 4- : Módulo Didático de Apoio ao Professor

Módulo Didático

ENSINO- APRENDIZAGEM DO CONCEITO DE “CÉLULA VIVA": PROPOSTA DE ESTRATÉGIA PARA O ENSINO FUNDAMENTAL 


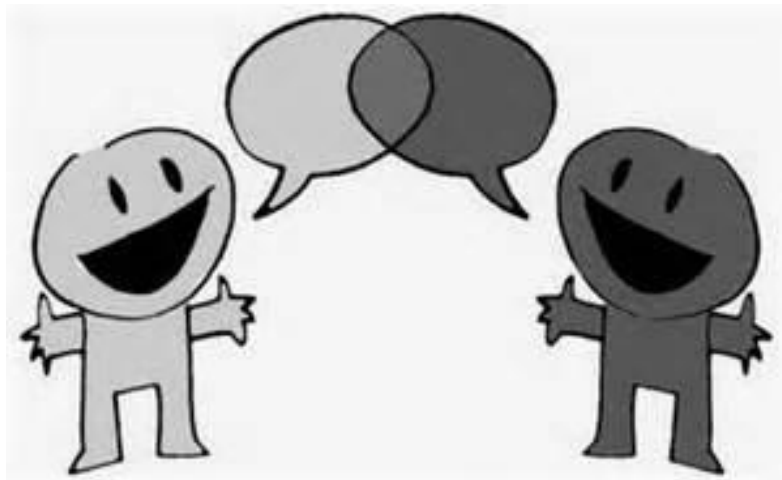

MÓDULO DIDÁTICO

ENSINO- APRENDIZAGEM DO CONCEITO DE "CÉLULA VIVA": PROPOSTA DE ESTRATÉGIA PARA O ENSINO FUNDAMENTAL

\section{RESUMO}

Nesse trabalho elaboramos um conjunto de atividades e reflexões que convergiram para um módulo didático, com a finalidade de oferecer um exemplo de trabalho produzido à luz de uma abordagem teórica que considera o conhecimento das concepções alternativas dos alunos. As ideias dos estudantes sobre as estruturas biológicas muitas vezes não coincidem com os conceitos cientificamente aceitos, mas não foi preciso desestruturar essas ideias, mas sim trabalhá-la paralelamente com a nova informação, visto que o aluno é capaz de conviver com concepções diferentes de um mesmo assunto.

Jacqueline A França

Ensino de Ciências 


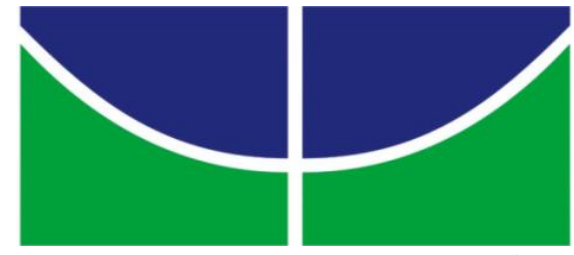

UNIVERSIDADE DE BRASÍLIA

Instituto de Ciências Biológicas

Instituto de Física

Instituto de Química

Faculdade UnB Planaltina

Programa de Pós-Graduação em Ensino de Ciências

Mestrado Profissional em Ensino de Ciências

\section{ENSINO- APRENDIZAGEM DO CONCEITO DE "CÉLULA VIVA": PROPOSTA DE ESTRATÉGIA PARA O ENSINO FUNDAMENTAL.}

JACQUELINE ALVES ARAÚJO FRANÇA

Proposta de ação profissional resultante da dissertação realizada sob a orientação da Prof. ${ }^{a}$ Dr. $^{\text {a }}$ Maria Márcia Murta e apresentada à banca examinadora como requisito parcial à obtenção do Título de Mestre em Ensino de Ciências - Área de Concentração "Ensino de Biologia", pelo Programa de Pós-Graduação em Ensino de Ciências da Universidade de Brasília.

BRASÍLIA- DF

Maio 2015 


\section{SUMÁRIO}

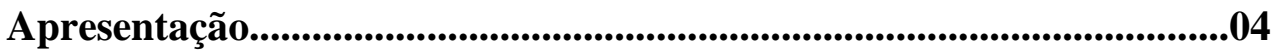

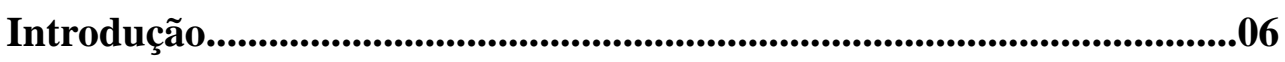

Estratégias Didáticas.................................................................................08

Referências Bibliográficas....................................................................34

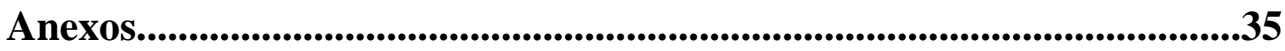




\section{APRESENTAÇÃO}

Olá, colega professor!

Estamos apresentando a você uma proposta de ensino sob a forma de um Módulo Didático, na expectativa de ajudá-lo a trabalhar com o conceito de célula para alunos do $8^{\circ}$ ano do Ensino Fundamental. O objetivo é contribuir para a reflexão e discussão sobre as dificuldades dos alunos na apreensão dos conteúdos relacionados ao conceito de célula, a fim de que eles possam utilizá-los sempre que forem solicitados, de forma ordenada e conectada aos demais conceitos do corpo humano.

Sou professora de Ciências Biológicas da Rede de Ensino do Sistema Colégio Militar de Brasil, sendo que a maior parte dos 11 anos que leciono no sistema estive alocada no $8^{\circ}$ ano do Ensino Fundamental. Sentindo a necessidade de melhorar a minha formação pedagógica busquei o Programa de Pós-Graduação em Ensino de Ciências da Universidade de Brasília (PPGEC), que prevê a elaboração de uma proposta de intervenção ao término do mestrado profissionalizante.

Refletindo sobre algumas das dificuldades encontradas ao longo da minha experiência profissional, verifiquei que aquela que me causou maior inquietação foi a limitada apreensão do conceito de células pelos alunos. Observei que esse conceito era recorrente ao longo do ano, no entanto, sempre que precisava dele, os alunos mostravam-se refratários; comentários como "não sei”, "não lembro" eram frequentes, mesmo quando usava exemplos de gravuras, de desenhos e outros meios didáticos na tentativa de dinamizar as aulas.

Durante o mestrado, fui levada a várias reflexões. Uma delas dizia que "as ideias alternativas dos estudantes desempenham um papel fundamental no processo de aprendizagem, já que só é possível aprender com base no que já é conhecido" (DRIVER, 1989, p.481). Era então preciso modificar estratégias e considerar que meu aluno pode possuir diferentes explicações acerca do mundo e os fenômenos da natureza, mas, algumas vezes, não precisariam necessariamente ser substituídas pelos conceitos científicos, ambas podiam conviver.

Foi então que fui apresentada à Teoria de Perfil Conceitual (TPC) que estabelece que um único conceito chave possa estar disperso entre vários tipos de concepções. 
Assim, qualquer pessoa possui mais de uma forma de compreender a realidade, que irá depender basicamente das experiências vividas por cada um e do contexto no qual tal conceito se insere.

Pelo fato da construção do conceito de célula estar no centro de um conjunto de conhecimentos científicos importantes dentro da biologia e de grande vulto nos dias atuais, compreendemos que sua apreensão em uma dimensão mais ampla pode ser vista como importante para o exercício da cidadania. Basta ver a necessidade que temos todos de nos posicionar frente a processos e inovações que nos afetam, como a engenharia genética; a utilização de células tronco, entre outros, que utilizam muitos dos conceitos celulares.

Dessa forma, decidimos utilizar os pressupostos da TPC como estratégia de ensino, visando melhoria na apreensão de conceitos celulares de forma ordenada e integrada ao corpo humano, seguindo os seguintes passos:

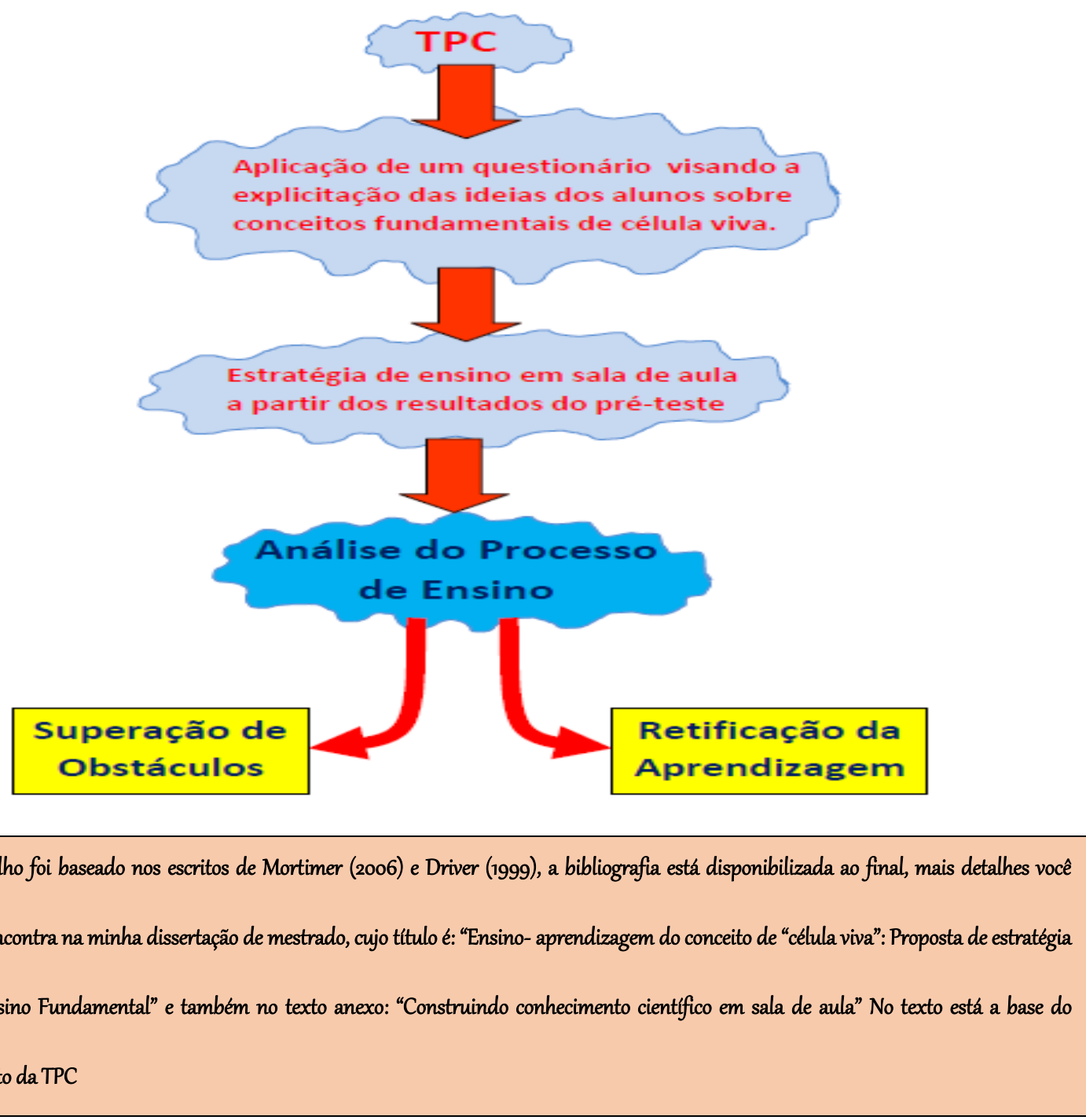

\footnotetext{
Esse trabalho foi baseado nos escritos de Mortimer (2006) e Driver (1999), a bibliografia está disponibilizada ao final, mais detalhes você também encontra na minha dissertação de mestrado, cujo título é: "Ensino- aprendizagem do conceito de "célula viva": Proposta de estratégia para o Ensino Fundamental" e também no texto anexo: "Construindo conhecimento científico em sala de aula" No texto está a base do pensamento da TPC
} 


\section{INTRODUÇÃO}

\section{ENSINO- APRENDIZAGEM DO CONCEITO DE "CÉLULA VIVA": PROPOSTA DE ESTRATÉGIA PARA O ENSINO FUNDAMENTAL}

O estudo das células teve início basicamente com o desenvolvimento de microscópios e de técnicas de preparo para visualização de materiais biológicos, a partir do século XVIII. Foram os primeiros estudos histológicos - pela observação de tecidos provenientes de várias espécies de animais e plantas - que levaram à formulação da TEORIA CELULAR, a qual estabelecia a célula como a unidade estrutural básica dos seres vivos. Quando estudamos a arquitetura das células (ou seja, o modo como elas estão arranjadas no tecido), a função de cada uma e a interação delas com o meio extracelular nos ajudam a entender melhor a estrutura e função de um órgão e de um sistema.

$\mathrm{Na}$ literatura encontramos estudos que apontam que o processo de ensino e aprendizagem de ciências têm revelado que os alunos apresentam concepções próprias, ou seja, conceitos intuitivos, espontâneos, alternativos a respeito de vários temas, que muitas vezes, distanciam-se dos conhecimentos científicos em vigor, não obstante, esse conhecimento, não precisa necessariamente ser abandonado. A Teoria do Perfil Conceitual (TPC), desenvolvida pelo professor Eduardo Mortimer, publicada em 1996, procurou compreender a convivência, num mesmo indivíduo, de várias representações de um mesmo conceito, desde aquelas de senso comum até as científicas.

Essa abordagem avalia as concepções prévias dos estudantes em sala de aula e pressupõe que essas concepções alternativas não sejam abandonadas ao longo do processo de ensino em detrimento de aquisições de concepções científicas, mas sim que possam conviver com as anteriores, podendo ser utilizadas em contextos convenientes.

Alguns autores ressaltam que a escola deve proporcionar o acesso a outras formas de conhecimento, “[...] sem desfazer o amálgama social representado pelas crenças de um povo". Não se pode dizer que entre conhecimento cotidiano e científico existam somente contradições, ou mesmo que um seja certo e o outro errado em termos absolutos, todavia cresce cada vez mais a defasagem entre uma minoria que se apropriou do saber sistematizado e a maioria dos sujeitos que continua analisando os fatos com base em saberes espontâneos, trazendo consequências culturais e sociais no 
mundo em que a maioria dos problemas de gestão tem base científica. Considerando-se esta assertiva, entendemos que a apreensão de conceitos básicos de células ainda no $8^{\circ}$ ano do EF seja fundamental, pois esses conceitos permeiam, além do EF, todo EM e superior.

Nessa perspectiva, entendemos que a apropriação do conhecimento científico se dá gradativamente, a partir da percepção do significado das palavras que expressam os conceitos referentes às células cientificamente aceitos, por meio da mediação social entre alunos e alunos e alunos e professor, mas algumas concepções prévias permanecerão e serão utilizadas em outros contextos. Todos esses pressupostos estão presentes na TPC.

A TPC foi fundamentada a partir de três eixos, que em linhas gerais podem ser assim descritos: Desenvolvimento da Cognição Individual; História e Filosofia da Ciência; Desenvolvimento social de ideias em sala de aula. Esse tipo de estudo já foi realizado em relação aos conceitos de reações químicas, átomo e de estados físicos dos materiais, calor, transformação e outros, ou seja, para alunos do EM e EF. Os três eixos, são dinâmicos e se articulam entre si.

OS TRÊS EIXOS QUE FUNDAMENTAM A TPC

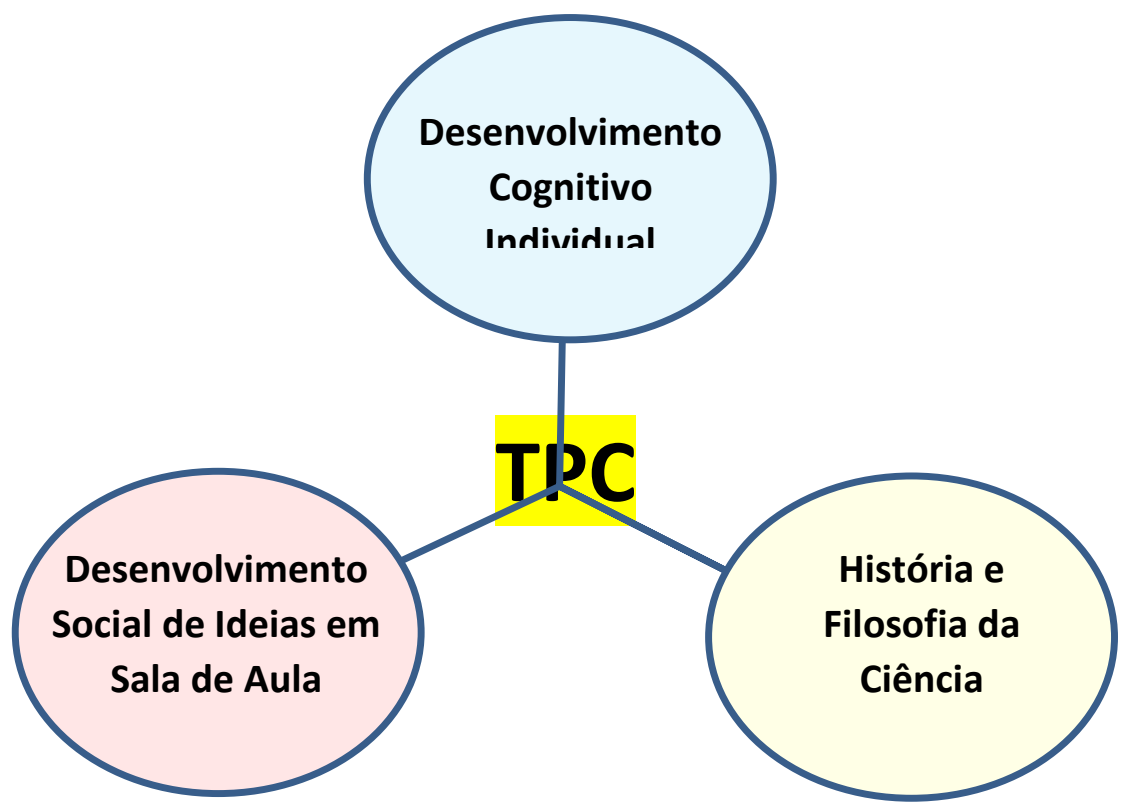

Para saber mais detalhes dos três eixos consulte minha dissertação na biblioteca digital da Universidade de Brasília que tem um pequeno resumo ou o livro: Linguagem e Formação de Conceitos no Ensino de Ciências de Eduardo Mortimer. 


\section{ESTRATÉGIAS DIDÁTICAS}

Professor (a),

O sucesso dessa atividade, de acordo com a TPC, envolve basicamente as seguintes etapas:

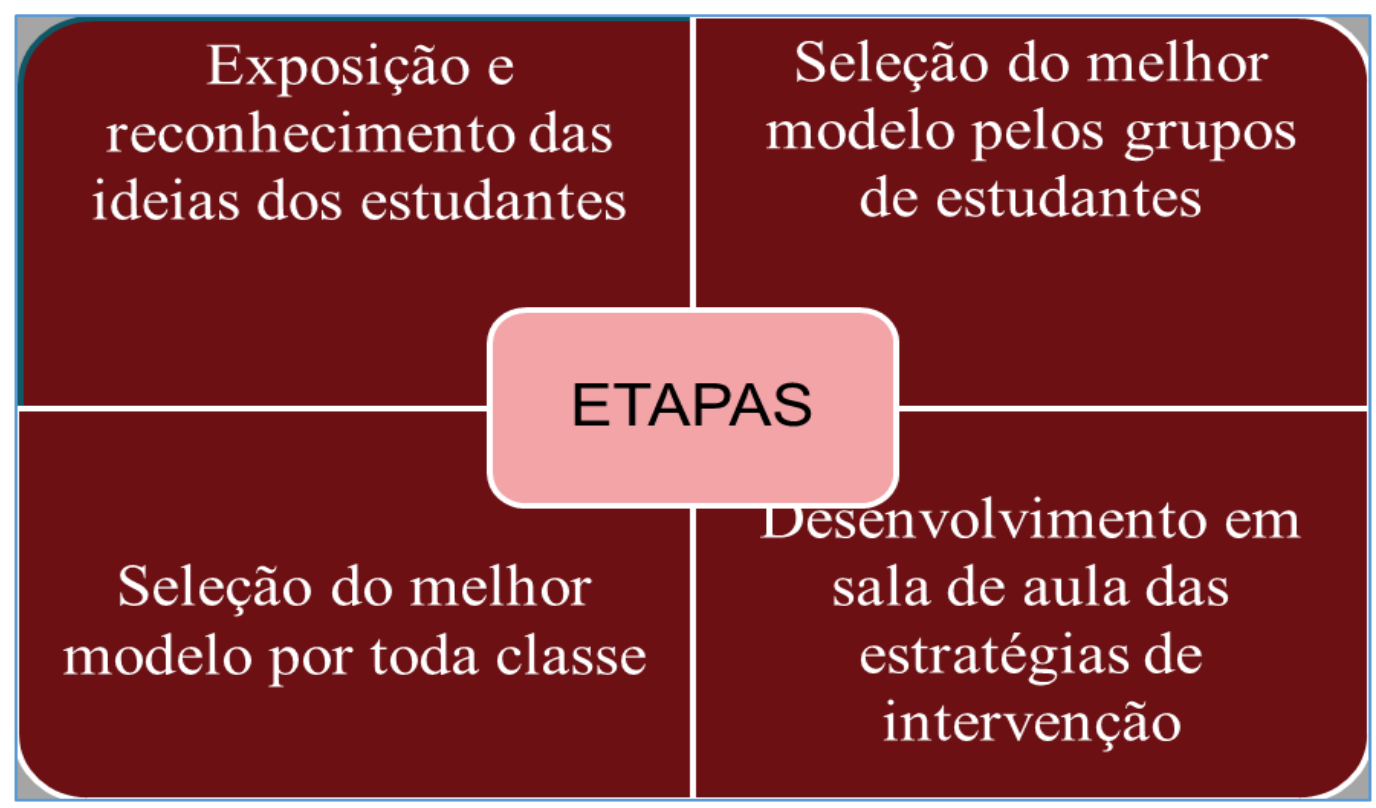

As atividades aqui propostas foram divididas em etapas com duração variável, de acordo com o número de aulas disponiveis:

PRIMEIRA ETAPA: APLICAÇÃO DE UM QUESTIONÁRIO DE EXPLICITAÇÃO DAS IDEIAS DOS ALUNOS A RESPEITO DOS CONCEITOS FUNDAMENTAIS DE CÉLULA VIVA.

O objetivo dessa etapa é explicitar ao máximo as ideias que os alunos trazem do seu cotidiano a respeito de célula, pois ao ser expostos essas ideias é possível que os obstáculos a apreensão dos conceitos científicos fiquem mais claros.

A intenção é convidar o aluno a demonstrar seu conhecimento a respeito do assunto e tentar entender qual a visão dele acerca do tema. Portanto, não há preocupação em como ele vai se expressar. É preciso deixa-lo à vontade para escrever, desenhar, esquematizar etc. É preciso também deixar claro que estamos tentando saber "o que ele acha”. 
Para elaboração das questões o professor deverá considerar o tempo disponível, tanto para aplicação, como para posterior análise das respostas. A seguir, passarei a alinhavar alguns exemplos de perguntas e respostas colhidas dos alunos do $8^{\circ}$ ano do Colégio Militar de Brasília onde realizei minha pesquisa foi.

\section{Professor (a)}

Como o questionário foi aplicado em um momento específico do ano letivo, sem muita flexibilidade, percebemos na dinâmica da pesquisa a necessidade de ter feitos outros questionamentos, como por exemplo, “para você, o que é célula?”.

$\left.1^{\circ}\right)$ "Biologicamente, do que você acha que somos feitos?" - É uma questão de natureza aberta, objetivou suscitar uma diversidade significativa de respostas, mas esperávamos especificamente que os alunos associassem o termo "biologicamente" à célula e respondessem que somos feitos de células.

Exemplo de respostas encontradas:

"somos feitos de organismos" I"nosso corpo é feito de milhões de microrganismos"/ "nosso corpo é feito de milhões de bactérias"

$2^{\text {) }}$ “Todos os seres vivos têm o mesmo número de células?” - a ideia era verificar as concepções dos estudantes em relação a um dos fundamentos da biologia, de que todos os seres vivos são formados por células: apenas uma nos organismos unicelulares, muitíssimas nos pluricelulares.

Exemplos de respostas encontradas:

“...assim como nós, as células vão morrendo” o aluno dissocia célula do próprio organismo

"à medida que ficamos mais velhos, as células aumentam ou diminuem de tamanho". A célula como estrutura estática, no que diz respeito a divisão celular e apoptose.

$3^{\circ}$ ) “As células são todas iguais"? - o objetivo era verificar a percepção que o aluno tem a respeito da diversidade de formas, funções e tamanhos das células.

Exemplos de respostas encontradas: 
"sim, as células são redondas" a célula como uma estrutura associada a um modelo único.

$4^{\circ}$ ) “Associe o termo célula a duas palavras:"- nós nos baseamos nos trabalhos de Bastos (1992) que trabalhou com conceitos celulares e usou o método da livre associação de ideias. O objetivo era de que o aluno fizesse alguma relação com organelas ou com partes da célula. Fizemos uma categorização baseado nas associações mais frequentes que apareceram e estão resumidas na tabela abaixo, algumas respostas pertenciam a categorias diferentes.

Respostas com maiores ocorrências.

\begin{tabular}{|c|c|c|}
\hline Categorias & Palavras citadas & $\begin{array}{l}\text { Quantidade de } \\
\text { alunos }\end{array}$ \\
\hline Microscópica & $\begin{array}{l}\text { Pequeno, menor, invisível, minúscula, micro } \\
\text { parte, partícula. }\end{array}$ & 30 \\
\hline Órgãos ou tecidos & Sangue, pele, pulmão, coração. & 32 \\
\hline Ser humano & Corpo, organismo, humano, ser humano & 26 \\
\hline Vida & $\begin{array}{l}\text { Essencial, saúde, elemento da vida, ser vivo, } \\
\text { energia vital, origem da vida. }\end{array}$ & 13 \\
\hline Moléculas & Gene, cromossomos, DNA, proteínas & 14 \\
\hline $\begin{array}{l}\text { Constituintes da } \\
\text { célula }\end{array}$ & $\begin{array}{l}\text { Membrana, citoplasma, núcleo, mitocôndrias, } \\
\text { nucléolo. }\end{array}$ & 21 \\
\hline
\end{tabular}

Por meio das respostas aos questionamentos pudemos compreender as perspectivas que os investigados têm a respeito da célula. Obviamente alguns detalhes são de difícil observação em apensas um questionário, de qualquer forma, abrem-se evidências e possibilidades de análise das interpretações alternativas. Com o retorno do pré-teste, procurei verificar se todas as perguntas foram respondidas adequadamente; observei algumas dificuldades e a necessidade de algumas alterações.

\section{SEGUNDA ETAPA: ESTRATÉgiA DE ENSINO EM SALA DE AULA, A PARTIR DOS RESULTADOS DO PRÉ-TESTE;}

Nesse momento utilizei algumas aulas para analisar as ideias dos alunos e fazer a intervenção. Aqui ocorreu a tomada de consciência dos diferentes perfis conceituais que os alunos trazem com eles e prevê a generalização dos conceitos celulares a partir de zonas mais elementares dos perfis dos alunos. 


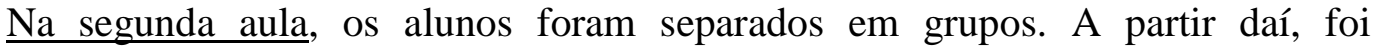
enfatizada a importância de cada aluno conhecer as respostas dos colegas para que pudessem eleger qual das respostas do questionário aplicado eles consideravam mais coerente. $\mathrm{O}$ objetivo dessa estratégia era explicitar a visão dos alunos.

Na terceira aula, de posse dos esquemas previamente selecionados pelos próprios alunos pude verificar com mais clareza onde estavam os erros conceituais mais expressivos, a influência das concepções espontâneas e quais respostas apresentava um padrão de repetições mais comum, além de outras observações.

$\underline{\text { Nas aulas subsequentes, }}$ os passos didáticos escolhidos, com base na TPC, podem ser assim generalizados:

I) a minha própria preparação, buscando conhecer a história pela qual o conceito de célula foi construído, além de assegurar que o tempo e aplicação da estratégia fossem cumpridos.

II) introdução do conteúdo de célula, onde foi feito o entrelaçamento com o que os alunos já conheciam a respeito, sempre explicitando ao máximo as ideias que eles trouxeram, só que agora eu conhecia suas ideias a respeito de célula;

III) tratamento da matéria nova, a qual teve como objetivo ajudar os alunos a tomar consciência de novas alternativas conceituais, sistematiza-las, pois como preconizam alguns pensadores do Ensino de Ciências: "o sucesso no ensino de uma ciência, como a biologia, deve ser medido pela capacidade do estudante de construir uma visão integrada e ordenada das redes de significados e práticas que constituem aquela ciência”. Nessa fase busquei que o aluno conseguisse no $8^{\circ}$ ano, especificamente integrar o conceito de célula ao estudo do corpo humano.

V) consolidação e aprimoramento dos conhecimentos. Não estávamos preocupados em realizar uma ruptura com as concepções prévias dos alunos, mas um enriquecimento de seus perfis conceituais, acompanhado por uma demarcação clara dos domínios de aplicação de cada modo de pensar e de falar. Era preciso que os conhecimentos novos fossem organizados, a fim de que estivessem disponíveis para orientá-los nas situações concretas de estudo e de vida. 
VI) controle e avaliação, aqui foi o momento de buscar observar se eles eram capazes de utilizar autonomamente conhecimentos e habilidades adquiridos, embora conscientes de que essa medida é um componente abstrato de difícil percepção.

\section{Obstáculos percebidos}

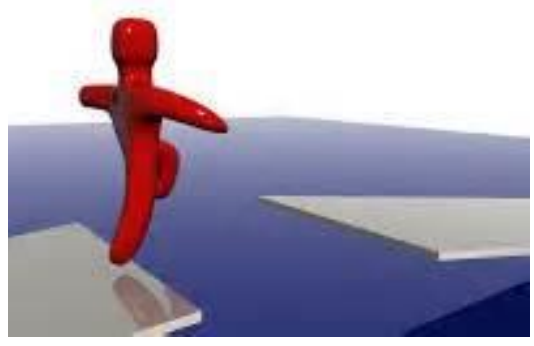

I) Dificuldade em se compreender a natureza microscópica da célula;

II) As figuras de células no livro didático (figuras estanques como se todas as células fossem iguais);

III) Assimilações inadequadas ou incompletas, adquiridas até na escola, tais como TODA célula é constituída de membrana plasmática, citoplasma e núcleo;

IV) Dificuldade com o vocabulário técnico.
V) Dificuldade em distinguir uma célula animal da vegetal ou de um eucarionte e procarionte.

Mortimer (2006) aponta como uma alternativa para a superação de obstáculos epistemológicos auxiliar os alunos a reconhecerem similaridades na diversidade aparente, eles podem ser levados a reconhecer características comuns nos modelos aparentemente diferentes que descreveram. $\mathrm{O}$ autor também chama a atenção para o fato de que a sala de aula é também um espaço de enculturação, cabendo ao professor explicitar os obstáculos epistemológicos e ontológicos que contradizem os conceitos científicos, além de dar oportunidade para que o estudante reflita sobre suas próprias ideias e generalize as novas por si só.

\section{Recursos Didático-Pedagógicos utilizados na compreensão do conceito científico de célula}

Com relação ao material didático, há muita flexibilidade, cabe ao professor uma atitude permanente de análise de suas aulas e, por decorrência, a análise dos materiais didáticos que podem dar maior contribuição em cada conteúdo. Em determinadas situações, a produção de materiais por mim foi a melhor forma de atender a 
especificidades de determinado conteúdo, por exemplo, usei muito a História da ciência e da microscopia na elaboração das aulas, que não eram contemplados no livro didático.

- Textos, livro didático e exercícios avulsos;

- Modelos de células;

- Microscopia;

- Estudo dirigido;

- Trabalhos em grupos;

- Internet e seus dispositivos

Os modelos abaixo busquei no laboratório de ciências do Colégio onde leciono, mas você pode utilizar modelos tridimensionais da internet.

Foto de modelos utilizadas em sala Foto do modelo de neurônio usada em sala mostrando a célula no processo de divisão de aula mostrando a diversidade de formas celular

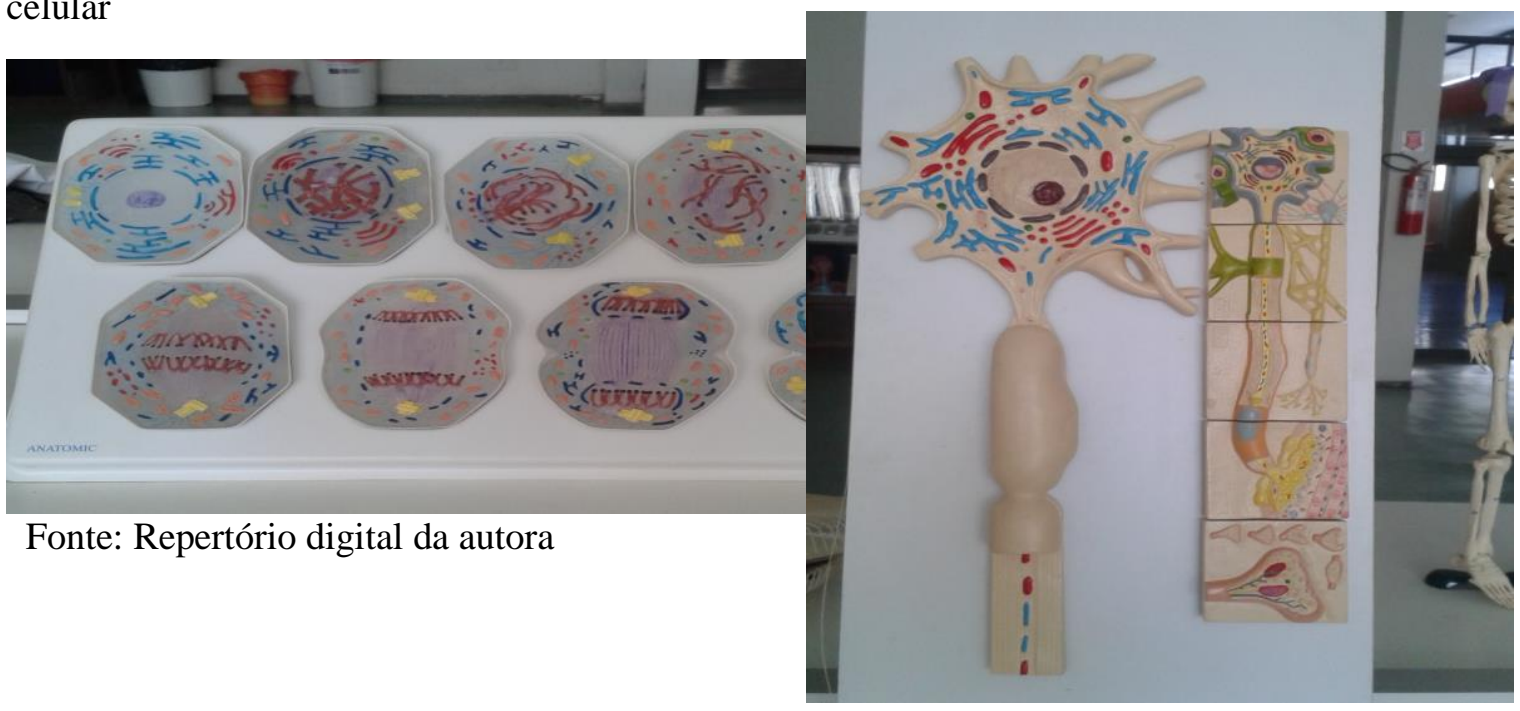

Fonte: Repertório digital da autora

\section{TERCEIRA ETAPA: ANÁLISE DO PROCESSO DE ENSINO}

É a etapa da superação dos obstáculos e retificação da aprendizagem. Na sequência da metodologia de trabalho, utilizamos o pós-teste, as avaliações formais e observações para aferir a evolução das concepções dos alunos. Um aspecto que considerei importante e que foi percebido durante o desenvolvimento do trabalho foi a heterogeneidade das ideias dos alunos acerca do conceito de célula.

Lembre-se! A finalidade do primeiro questionário foi de investigar os conhecimentos prévios a respeito do tema proposto para as aulas: a Célula. Finalizadas 
as aulas, aplicou-se novamente o questionário para se determinar em que medida houve ampliação dos conhecimentos científicos pelos alunos ou como esses novos conhecimentos conviviam com os conceitos alternativos trazidos por eles.

O aluno chegou à escola respondendo que "somos feitos de carne e osso" como apareceu no pré-teste, porque esse é o pensamento do senso comum, essa é a linguagem ouvida no seu cotidiano. A partir daí, o levei a pensar de que é feito essa "carne" e “osso?" será o osso apenas uma estrutura de sustentação da "carne?" ou possui outras funções? É feito apenas de uma estrutura mineralizada ou também possui células? qual a relação entre essas partes e outros tecidos do corpo humano? será que o músculo experimenta certos processos de natureza bioquímica e biofísica, a ponto de se diferenciar de suas características originais, passando a ser considerado "carne"? Segundo a TPC é possível o aluno manter esse pensamento, mas adquirir contornos explicativos mais amplos e usa-los nos momentos oportunos cada um deles.

O primeiro questionamento do pós-teste proposto continha a seguinte pergunta: 1) Tanto os organismos unicelulares como as células dos vários tecidos dos pluricelulares são muito diferentes entre si. Apesar dessa enorme variedade, quais os três componentes básicos da maioria das células animais eucariontes?

Respostas dos alunos a primeira questão do pós-teste

\begin{tabular}{|c|c|c|}
\hline Categorias & Respostas & Percentual (\%) \\
\hline Não responderam & 7 & 5,30 \\
Respostas incompletas & 10 & 7,57 \\
Erradas & 12 & 9,09 \\
Corretas & 103 & 78,03 \\
\hline
\end{tabular}

O segundo questionamento foi assim descrito: 2) A palavra célula foi usada pela primeira vez em 1665, pelo cientista inglês Robert Hooke. Com um microscópio muito simples, ele observou pedacinhos de cortiça. Hooke percebeu que a cortiça era formada por numerosos compartimentos vazios. O termo célula (do latim Cellula = compartimento vazio) foi introduzido na linguagem científica a partir da observação de material vegetal morto em microscópio rudimentar. Agora, suponha que Robert Hooke 
tivesse observado células vivas ao microscópio, e não células mortas de cortiça. Baseado nos seus conhecimentos sobre estrutura celular atual, o nome célula seria o mais adequado? Por quê?

O objetivo era fazer uma triangulação entre a História da Ciência, incluindo a microscopia, já que foi muito recorrente na aula e os conceitos celulares atuais discutidos em sala, seja célula morta/viva e animal/vegetal, tentando perceber a tomada de posição do aluno frente a essas questões. Obtivemos os seguintes resultados:

Respostas dos alunos a segunda questão do pós-teste

\begin{tabular}{|l|l|l|}
\hline \multicolumn{1}{|c|}{ Categorias } & \multicolumn{1}{|c|}{ Respostas } & Percentual (\%) \\
\hline Erradas & 9 & 6,8 \\
\hline Com erros conceituais & 12 & 9,0 \\
\hline Não responderam & 9 & 6,8 \\
\hline Corretas & 102 & 77,3 \\
\hline
\end{tabular}

Observamos ainda a dificuldade persistente dos alunos com a linguagem científica. Frases tais como: "o nome está incorreto, pois dentro da célula há várias coisinhas" ou " a célula não é um ser vazio, pois dentro dela tem algo nesse espaço que fazem coisas" (grifo da autora); percebemos que o aluno nesse caso, reconhece que há partes na célula responsável pela produção de energia e pela síntese de proteínas, mas continuaram chamando as organelas de "coisas", "algo" e até "seres"

O terceiro problema: $O$ encéfalo humano é um dos órgãos que apresenta maior irrigação sanguínea. Isto está relacionado ao fato de suas células demandarem grande quantidade de energia. Explique de que maneira o grande volume de sangue contribui para a produção de energia nas células do encéfalo humano?

Essa questão buscou avaliar, dentro da perspectiva da TPC, alguma evidência do alcance de generalização do aluno, pois sendo uma questão feita já ao final do ano letivo, esperávamos que o aluno explicitasse noções de órgãos (encéfalo), tecido (sanguíneo) e metabolismo energético. “...propriedades essenciais ou sistêmicas (todo) não se encontram nas partes isoladas, só no conjunto, surgem das relações de organização". Queríamos aferir algum potencial de visão sistêmica.

Respostas dos alunos ao terceiro problema 


\begin{tabular}{|c|c|c|c|c|}
\hline \multicolumn{2}{|c|}{ Categorias } & Respostas & Exemplos & Percentual \\
\hline \multirow[t]{2}{*}{ Corretas } & Complexas & 19 & $\begin{array}{l}\text { "o encéfalo é uma região importante } \\
\text { que necessita de grande quantidade } \\
\text { de glicose e oxigênio trazidos pelo } \\
\text { sangue" } \\
\text { "as hemácias do sangue transportam } \\
\text { oxigênio e o plasma transporta } \\
\text { nutrientes necessários para produção } \\
\text { de energia no encéfalo" }\end{array}$ & 14,4 \\
\hline & Simples & 81 & $\begin{array}{l}\text { "o sangue é um tecido } \\
\text { transportador" }\end{array}$ & 61,4 \\
\hline \multicolumn{2}{|c|}{ Não responderam } & 23 & $\mathrm{XXX}$ & 17,4 \\
\hline \multicolumn{2}{|c|}{$\begin{array}{l}\text { Erradas ou sem } \\
\text { entendimento }\end{array}$} & 9 & $\begin{array}{l}\text { "devido à grande quantidade de } \\
\text { mitocôndrias soltas no sangue" }\end{array}$ & 6,8 \\
\hline
\end{tabular}

Subdividimos a categoria correta em "complexa" e "simples", por consideramos que algumas respostas demonstravam um nível de uniformização maior e com maior objetividade (as simples) já outras (as complexas) traziam maior diversidade de ideias, com maior grau de estruturação e com uma visão mais sistêmica.

A quarta e última questão do pós-teste: Defina com suas palavras, a partir dos conhecimentos adquiridos, o que é célula? Buscamos uma resposta com caráter mais direto. Esperávamos que o aluno respondesse que a célula é a menor parte dos seres vivos com forma e função definidas. O resultado foi compilado no quadro 9 abaixo:

Resultado das respostas dos alunos a questão 4 do pós-teste

\begin{tabular}{|l|c|c|}
\hline \multicolumn{1}{|c|}{ Categorias } & Respostas & Percentual (\%) \\
\hline Não sabiam ou em Branco & 8 & 6,0 \\
\hline $\begin{array}{l}\text { Erradas ou com falhas } \\
\text { conceituais }\end{array}$ & 28 & 21,2 \\
\hline Corretas & 96 & 72,7 \\
\hline
\end{tabular}


Nessa questão observamos que a maior parte dos alunos conseguiu expressar suas ideias acerca da estrutura celular, suas organelas, as limitações do instrumento de medida da época e outros. Os alunos explicitaram nas respostas que os Eucariontes (com envoltório nuclear) apresentam uma organização mais complexa com estruturas chamadas de organelas, bem diferentes do que Hook havia observado no passado, por isso não poderia ser chamado de célula. Durante as aulas levamos modelos celulares para que eles percebessem a correlação entre organelas, DNA e cromossomos.

\section{Informações básicas a respeito de conceitos celulares atualmente aceitos que enfatizamos nas aulas}

a) A célula é a unidade básica dos seres vivos. Há seres vivos que apresentam uma só célula, são unicelulares. É o caso dos seres vivos pertencentes ao reino Monera e de muitos outros pertencentes ao reino Protista. As plantas e os animais são constituídos de numerosas células, são pluricelulares;

b) O ser humano tem o seu corpo composto de um número muito grande de células, todas com organização semelhante. Há muitos tipos de células, que se encontram associados no organismo formando tecidos;

c) Todas as células possuem partes ou estruturas que contribuem para o seu funcionamento como um todo;

d) A maioria das células pode ser descrita como uma unidade envolvida por uma membrana e constituída por um citoplasma e um núcleo;

e) A membrana celular controla a entrada e saída de substâncias na célula;

f) O citoplasma é a maior porção da célula, compreendida entre a membrana e o núcleo. Seus compostos mais abundantes são a água e a proteína. Nele se encontram corpúsculos, que são os "pequenos órgãos" da célula, por isso são denominadas organelas;

g) O núcleo funciona como o centro de controle da célula, nele se encontram os cromossomos, filamentos de DNA que representam o material genético do indivíduo;

h) A célula vegetal distingue-se fundamentalmente da célula animal por apresentar parede celular e cloroplastos. 


\section{Sugestões de planos de aula}

O pré-teste já foi aplicado, as ideias alternativas dos alunos expostas, foram escolhidos os melhores modelos explicativos tanto dos grupos quanto da sala.

1) Objeto do conhecimento: Célula

2) Objetivos:

a) Indicar os componentes essenciais de uma célula.

b) Relacionar as funções vitais das células com seus componentes.

c) Estabelecer diferenças entre vários tipos de células a partir da observação microscópica, da análise de fotos e esquemas e da construção de modelos.

d) Compreender as funções vitais como nutrição, transporte, excreção, digestão e respiração que ocorrem no organismo, relacionando-os as células.

e) Analisar mecanismos de integração de sistemas em situações cotidianas

3) Mediação das Atividades:

Aula 01:

Em sala:

- Aula de laboratório: uso de microscópio e identificação de suas partes, ver no microscópio uma célula animal e vegetal (similaridades e diferenças).

- Diálogo a respeito da história da microscopia e da história da célula.

Em casa:

- Pesquisar na internet imagens de células procarióticas e eucarióticas (animais e vegetais) anotando os nomes de todas as organelas visualizadas e trazer para discussão.

\section{Aula 02:}

Em sala:

- Organização em grupos para analisar as imagens pesquisadas encontrando semelhanças e diferenças.

- Aula expositiva- sistematização dos diferentes grupos celulares.

- Níveis de organização dos seres vivos.

Em casa:

- Montar um glossário com os termos: Unicelulares, pluricelulares, procariontes, eucariontes.

- Pesquisar imagens de organelas celulares e trazer. 
- Pesquisar imagens de núcleos celulares, comparando como se comporta a célula procarionte e eucarionte e trazer para aula.

\section{$\underline{\text { Aula } 03}$}

Em sala:

- Em grupo: ver e manusear modelos de células eucariontes.

- Considerações a respeitos das organelas citoplasmáticas e suas funções: cada um montar sua própria célula.

Em casa:

- Folha de atividades

4) Material de Apoio: Questionários, modelos de células, microscópio, textos, livro didático, internet.

Aula baseada em "AMABIS, José Mariano; MARTHO, Gilberto Rodrigues. Fundamentos da Biologia Moderna. Volume único, 4 ed. São Paulo: Editora Moderna, 2006."

Fazendo algumas reflexões após a finalização da pesquisa e na busca pelo aprimoramento do processo, algumas atitudes didáticas eu redefiniria para próximos trabalhos, entre elas destaco o período em que foi aplicado o pós-teste. Como foi aplicado no quarto bimestre, devido a meu entendimento de que teria mais tempo para intervenção, não consegui aferir com mais acuidade a evolução das ideias dos alunos, embora tenha utilizado outros instrumentos formais de avaliação da escola em que trabalho e as observações pessoais. Assim aplicaria o pós-teste no final do segundo bimestre.

Outra atitude seria diminuir o número de conceitos avaliados, fixando-me mais na teoria celular, a fim de me aprofundar um pouco mais na evolução do pensamento do aluno, primeiro pela limitação do tempo letivo e também pelo currículo impositivo, se for o caso.

Com relação aos recursos utilizados na intervenção, entendemos que a avaliação mais precisa dos materiais didáticos deva ser feita pelo aluno, público a quem são destinados. $\mathrm{O}$ aluno durante o processo de aprendizagem consegue diagnosticar de maneira mais legítima as dificuldades de uso; todavia dialogando com os alunos a respeito dos recursos e da maneira como foram conduzidos os trabalhos, eles afirmaram 
que gostaram do formato de trabalhar em grupo e participar das decisões de escolher do melhor modelo, além da aula prática, da história da célula, das imagens e outros.

Não obstante, minha leitura é que os resultados poderiam ser melhores se fossem mudadas algumas sequências de aplicação, como por exemplo, o glossário, aplicando-o desde o início da intervenção. O glossário auxiliou à medida que usamos termos cujo significado não era ambíguo, familiarizou os termos, indicou as propriedades definidoras e não demandou tempo em sala, já que era uma atividade extraclasse.

\section{História da Célula}

As células foram descobertas em 1665 pelo inglês Robert Hooke. Ao examinar em um microscópio rudimentar, uma lâmina de cortiça, Hooke verificou que ela era constituída por cavidades poliédricas, às quais chamou de células (do latim cella, pequena cavidade). $\mathrm{Na}$ realidade Hooke observou blocos heradecimais que eram as paredes de células vegetais mortas. A teoria celular foi formulada em 1839 por Schleiden e
Schwann, que concluíram que todo ser vivo é formado por células. Abaixo desenho esquemático do microscópio rudimentar utilizado por Hooke.

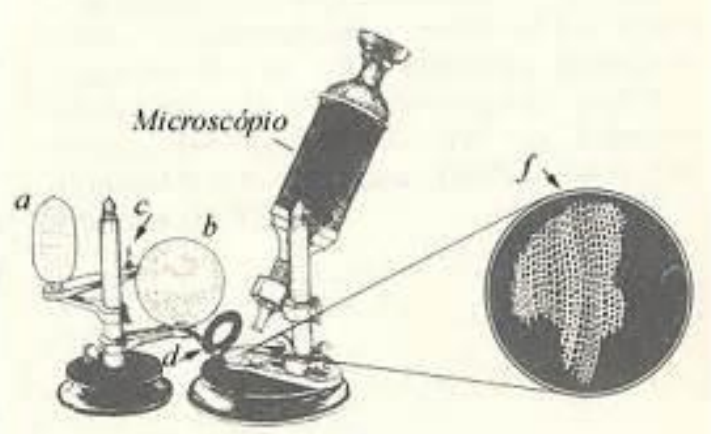

\section{Diferenças entre eucariontes e procariontes}

As células procariontes ou procariotas (a figura a sua esquerda) são diferentes das eucariontes. Sua maior diferença é que as células procariontes não possuem carioteca. A carioteca é uma membrana que separa o material genético do citoplasma. As células eucariontes ou eucariotas (a figura logo abaixo) possuem a carioteca, individualizando o material nuclear da célula.

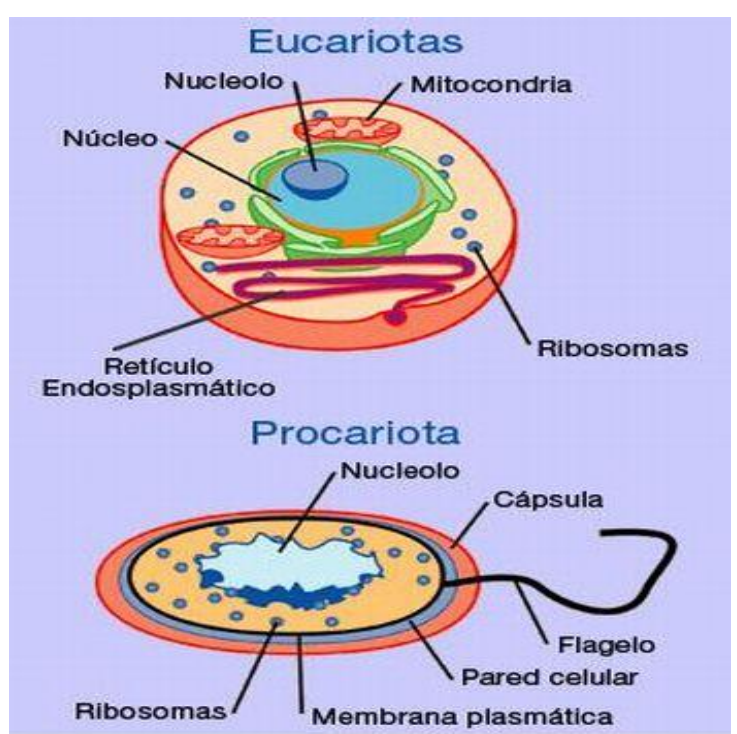


Imagem retirada de: http://www.windows2universe.org/earth/Life/images/celltypes.sp.gif (consultado em 10/01/2015

\section{Sugestões de links para trabalhar em sala ou em casa}

- http://pt.slideshare.net/guestdb5b7a/celula-2011687?related=2

- http://pt.slideshare.net/catir/a-clula-unidade-bsica-da-vida-presentation?related=1

- http://pt.slideshare.net/emcoeliribas/apresentao1-celulas-5-ano-8196204

- http://pt.slideshare.net/jonaskiko/a-clula-1035581?related=2

- http://pt.slideshare.net/Jhonatanmorandi/16-022012-celulas-e-tecidos?related=2

- http://pt.slideshare.net/veneranto/corpo-humano-final?related=1

- http://cienciasempre.blogspot.com.br/2014/01/citologia-o-estudo-das-celulas.html

- http://www.todabiologia.com/botanica/celula_vegetal.htm

- http://biologia-celular.info/

- http://portaldoprofessor.mec.gov.br/fichaTecnicaAula.html?aula=25547

A seguir apresentaremos algumas atividades que podem ser utilizadas em suas aulas. Elas poderão ser aprofundadas caso queira atingir alunos do ensino médio, os quais estudam células em um grau mais aprofundado. No $8^{\circ}$ ano, o mais importante é que as atividades ajudem o aluno a compreender a célula, correlacionado ao estudo dos tecidos, órgãos e do corpo humano como um todo, sob a perspectiva científica, linguagem científica, a histórica e até mesmo a tecnologia implícita. 


\section{ATIVIDADE 1}

Trabalhando com a História ( Linha do Tempo) para melhor compreender a construção do conhecimento celular

Caro professor (a)!

Essa atividade pode ajudar o aluno a reconhecer os acontecimentos do passado, fazendo pontes com o momento presente. Trazer o aluno para o centro da discussão e tentar mostrar que os feitos históricos e culturais da humanidade são frutos do trabalho árduo e dedicado de uma coletividade, não apenas de atos individuais e "isolados", ou seja, foi construído e compartilhado. Nesse sentido, sugerimos a linha do tempo como uma atividade em que ele não seja um mero expectador, mas um agente capaz de refletir e integrar conhecimentos: a história e a ciência caminham juntas.

Pode adequar sua linha do tempo de acordo com o tempo disponível, buscar imagens para dar mais ludicidade e projetá-las seguindo as datas. Na minha pesquisa utilizei somente alguns recortes.

1665 - Robert Hooke - Publica os primeiros desenhos de células observadas ao microscópio: células mortas de cortiça.

1831 - Robert Brown - Estudando partes das plantas ao microscópio descobre o núcleo das células.

1865 - Gregor Mendel - Demonstra a existência de elementos individuais e autorreplicáveis, posteriormente chamados de genes, responsáveis pela manifestação das características hereditárias.

$\underline{1869}$ - Friedrich Miescher - Encontra uma nova substância orgânica, isolada de núcleos de células de pus humano, denominada nucleína. Vinte anos mais tarde foi chamada de ácido nucléico.

1879 - Walther Flemming - Descreve o comportamento dos cromossomos durante a divisão celular.

1915 - Thomas Morgan - Estabelece a relação entre genes e cromossomos, e formula a teoria cromossômica da herança.

1923 - Robert Feulgen - Pelo método de coloração DNA-específico fortalece a teoria de que os genes estão localizados nos cromossomos.

1929 - Phoebus Levene - Descreve a composição química dos ácidos nucléicos.

1944 - Oswald Avery - Comprova, após alterar a descendência de uma bactéria com o DNA de outra, que esta substância é o material genético, abolindo de vez a tese de que as informações hereditárias estariam guardadas nas proteínas.

1950 - Erwin Chargaff - Verifica que existe uma proporção aproximada de 1:1 entre as bases nitrogenadas adenina (A) e timina (T) e 1:1 entre citosina (C) e guanina (G).

Início da década de 50 - Alexander Todd - Estuda minuciosamente os nucleosídeos (base nitrogenada ligada a um açúcar) e conclui que estes estão ligados a grupos fosfatos das moléculas de desoxirribose, o açúcar do 
DNA.

1952 - Rosalind Franklin - Descobre, entre outras características, que os grupos fosfatos do DNA estão situados na parte externa da molécula e que esta é formada por cadeias antiparalelas. Estas informações oferecem fortes indícios de qual seria a conformação espacial da estrutura da molécula de DNA.

1953 - Francis Crick e James Watson - Desvendam a estrutura da molécula de DNA, constituída por uma dupla hélice.

1977 - Frederick Sanger - Elabora uma técnica capaz de determinar a ordem sequencial das bases nitrogenadas do DNA de qualquer organismo vivo.

1983 - Kary Mullis - Idealiza uma técnica experimental que permite obter múltiplas cópias de um fragmento qualquer de DNA.

1985 - Alec Jeffreys - Desenvolve a técnica precursora do teste de paternidade e com a qual é possível identificar cada pessoa por meio do que, segundo o próprio pesquisador, seria um "código de barras" humano. 1996 - Ian Wilmut - Nasce o primeiro clone de um mamífero adulto, a ovelha Dolly, obtido por a partir de uma célula da glândula mamária.

2000 - Pesquisadores paulistas - Sequenciamento do genoma da bactéria Xylella fastidiosa, causadora da doença do amarelinho em cítricos.

2001 - A empresa Celera Genomics e um consórcio de laboratórios internacionais (Organização do Genoma Humano) - Rascunho do mapeamento do genoma humano, revelando que este é formado por aproximadamente 30 mil genes, e não 100 mil, como era até então estimado.

Fonte: Espaço interativo de Ciências: Disponível em http://cbme.usp.br/index.php/material-de-apoio/145linhadotempo.html. Acesso em 10 mar 2015 


\begin{abstract}
ATIVIDADE 2
Trabalhando com montagem de célula, utilizando figurinhas coloridas, objetivando a apreenção de conceitos sobre organelas e núcleos, suas formas, funções, nomeclatura científica e outros.
\end{abstract}

a) trazer ( de casa) diversas imagens prévias de células, animal e vegetal.

b) a seguir, conduzimos a pergunta: $\mathrm{O}$ que a célula tem?,são apresentados os passos para a montagem de um modelo de célula animal, que depois será transformada em uma célula vegetal.

c) cada aluno foi montando seu modelo de célula, utilizando seu kit de montagem de modelo de célula individual (que é uma versão impressa da internet), onde ele recortou cada organela e estrutura celulares. Conforme cada uma e sua função correspondente foram sendo apresentadas pelo professor, o aluno as recortou de seu kit de montagem de modelo de célula, posicionando, corretamente, cada uma dentro da figura do citoplasma, colorindo e colando posteriormente.

d) começando como uma célula procarionte, avançando para uma eucarionte, todas as organelas e estruturas foram sendo incluídas no citoplasma passo a passo, até a finalização do modelo.

e) completado o modelo de célula animal, o aluno precisou transformá-lo num modelo de célula vegetal, com a inclusão de cloroplastos e vacúolos no citoplasma e com a célula montada sendo colada dentro da figura que representa a parede celular. 


\section{ATIVIDADE 3}

Trabalhando com os vários níveis hierárquicos de organização dos seres vivos, iniciando pelo átomo e chegando ao organismo humano, podendo ampliar até a biosfera. A ideia é contextualizar a célula para fundamentar o estudo do corpo humano ao longo do ano.

Solicitar que os alunos se organizem em grupos (a distribuição das tarefas dependerá do número de alunos por sala) e tragam materias de casa (imagens, figuras etc)

1) Numerar os grupos e orientá-los, conforme sugestão abaixo:

- grupo 1: desenhar o átomo, a molécula e uma organela presente na célula animal.

- grupo 2: desenhar a célula eucariótica animal, com diferentes organelas em seu interior.

- grupo 3: desenhar um tecido e um órgão correspondente.

- grupo 4: desenhar o sistema relacionado ao órgão anterior.

- grupo 5: desenhar o corpo humano.

2) Discutir com os alunos os níveis de organização, utilizando os desenhos elaborados. 
ATIVIDADE 4

Trabalhando com comparações de células Eucarioto e Procarioto/ Animal e Vegetal

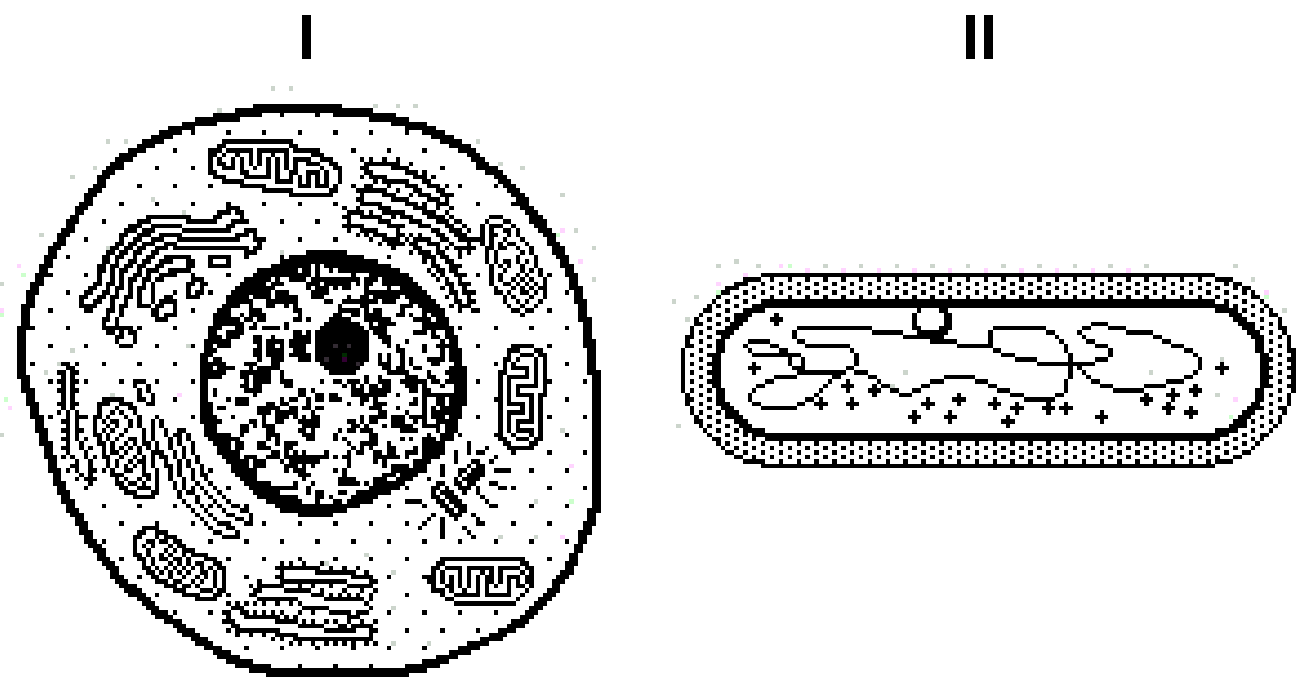

SOARFS, J. L.: "Biologia". São Paulo: Scipione, vol. único, 1999 . p. 38 e 44.
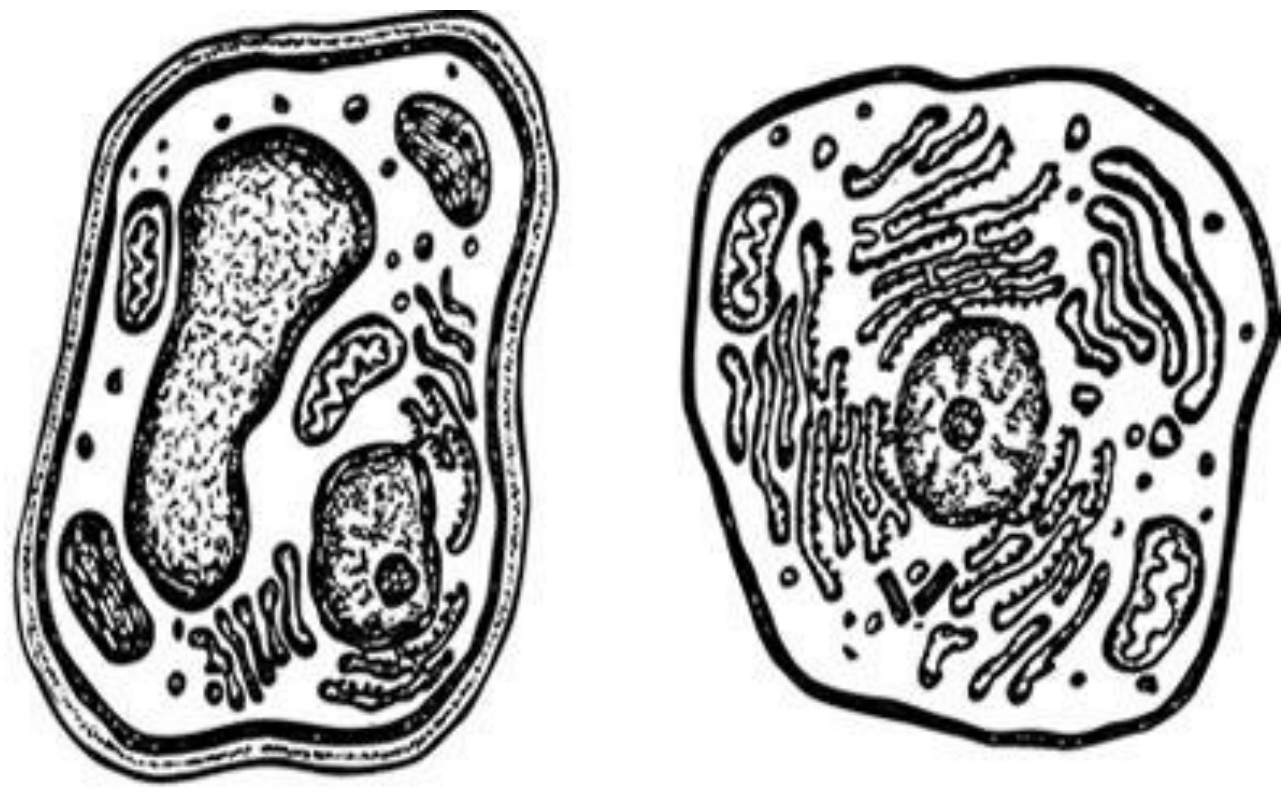


\section{ATIVIDADE 5}

Trabalhando com exercícios

1) Quem foi o primeiro cientista a observar as células? Como ele fez isso?

2) Diferencie seres unicelulares dos seres pluricelulares

3) O que afirma a teoria celular?

4) Diferencie célula animal da célula vegetal com relação a: Parede celular, cloroplastos e membrana plasmática

5) A figura abaixo mostra o esquema do corte de uma célula, observada ao microscópio eletrônico.

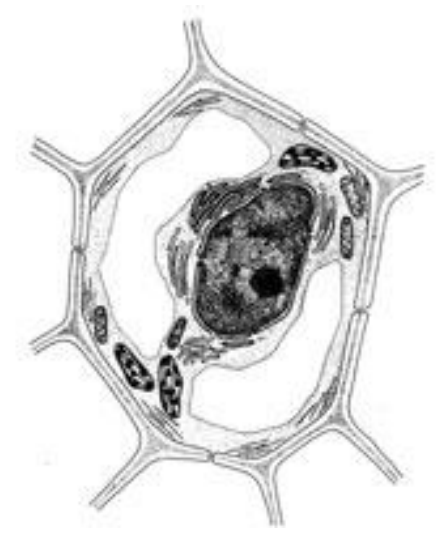

a) A célula é proveniente de tecido animal ou vegetal? Justifique. 


\section{ATIVIDADE 6}

Trabalhando com exercícios e imagens a respeito das organelas citoplasmáticas

Considerando as estruturas apontadas no esquema abaixo, responda ao que se pede:

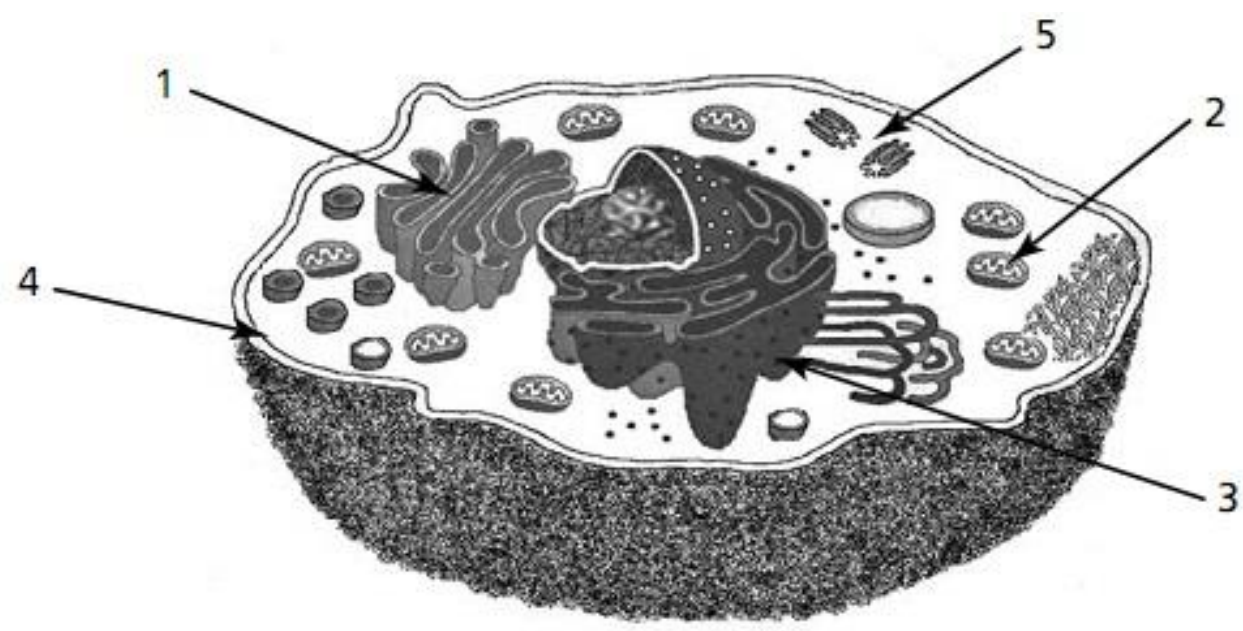

Fonte: http://crv.educacao.mg.gov.br (modificado)

1) Analise a frase: “Toda célula viva possui membrana plasmática, mas pode não possuir núcleo e mitocôndrias" Essa declaração será falsa ou verdadeira? Defenda seus argumentos:

2) Qual o nome da organela 2?

3) A quantidade da estrutura 2 no interior da célula depende de alguma necessidade específica?

4) Qual uma importante função da estrutura 4?

5) Por que a estrutura 1 é bem desenvolvida em células glandulares? 


\title{
ATIVIDADE 7
}

Trabalhando com texto: Ciência e Tecnologia. Discutir a importância da tecnologia.

\section{Novo nanotermômetro é capaz de medir temperatura de células}

\author{
Por Ricardo Schinaider de Aguiar \\ $14 / 08 / 2013$
}

Um novo tipo de termômetro, de escala microscópica, servirá não para medir a temperatura corporal, mas sim a temperatura de células específicas. O chamado "nanotermômetro", desenvolvido por uma equipe de pesquisadores da universidade de Harvard, consegue detectar variações de milésimos de graus celsius que ocorrem dentro de células vivas. O dispositivo poderá ajudar a elucidar processos de biologia celular e tem potencial para ser utilizado na detecção de cânceres.

Para medir temperaturas com essa precisão, os cientistas utilizaram pequenos cristais de diamante. O diamante, quando puro, é constituído apenas por átomos de carbono. Os cristais usados, porém, continham impurezas, geralmente causadas pela substituição de alguns átomos de carbono por átomos de nitrogênio. Quando iluminados com um laser de luz verde, os diamantes ficam fluorescentes com luz vermelha. A intensidade da luz vermelha, devido às impurezas, varia de acordo com a temperatura. Assim, monitorando a intensidade da fluorescência dos cristais, é possível medir a temperatura do ambiente ao seu redor.

A técnica foi aplicada em uma célula de embrião humano. Os cristais de diamante, de aproximadamente 100 nanômetros de diâmetro, foram injetados dentro da célula através de um nanofio. Os pesquisadores foram capazes de detectar variações de temperatura de até $0,044^{\circ} \mathrm{C}$ dentro da célula. Após o experimento, os pesquisadores afirmaram que a sensibilidade do nanotermômetro é cerca de dez vezes maior do que qualquer dispositivo para medir temperatura dentro de células vivas, mas que ainda pode melhorar. Quando testado fora de células, o nanotermômetro conseguiu medir variações de até $0,0018^{\circ} \mathrm{C}$.

"Nós temos agora uma ferramenta para medir temperatura em nível celular e podemos estudar como sistemas biológicos reagem a variações de temperatura", diz Peter Maurer, um dos autores do estudo. As possíveis aplicações do nanotermômetro vão desde pesquisas básicas em biologia até pesquisas aplicadas em medicina. Diversos processos biológicos, como expressão gênica e metabolismo celular são afetados pela temperatura e podem ser estudados com o termômetro de diamante, bem como o desenvolvimento embriológico de organismos mais simples, como o nematódeo $C$. elegans. "Podemos, por exemplo, aumentar a temperatura de determinadas células e analisar se as células à sua volta diminuem ou aumentam sua taxa de reprodução".

Além disso, o nanotermômetro tem potencial para ser utilizado até mesmo na detecção de cânceres, já que células de tumores malignos possuem um metabolismo mais rápido e temperatura mais elevada em relação às células de tecido saudável.

Fonte: Com Ciências, revista eletrônica de jornalismo científico 


\section{ATIVIDADE 8}

Trabalhando a diversidade celular, o objetivo é mostrar que mesmo com a diversidade, no seu conjunto as células estabelecem relações e divisão de trabalho, promovendo então o funcionamento dos tecidos e órgãos, as células porém apresentam memória estrutural, ou seja, apesar de representar uma infinitésima parte do todo nos organismos multicelulares, a célula faz parte de um todo integrado, o organismo.:

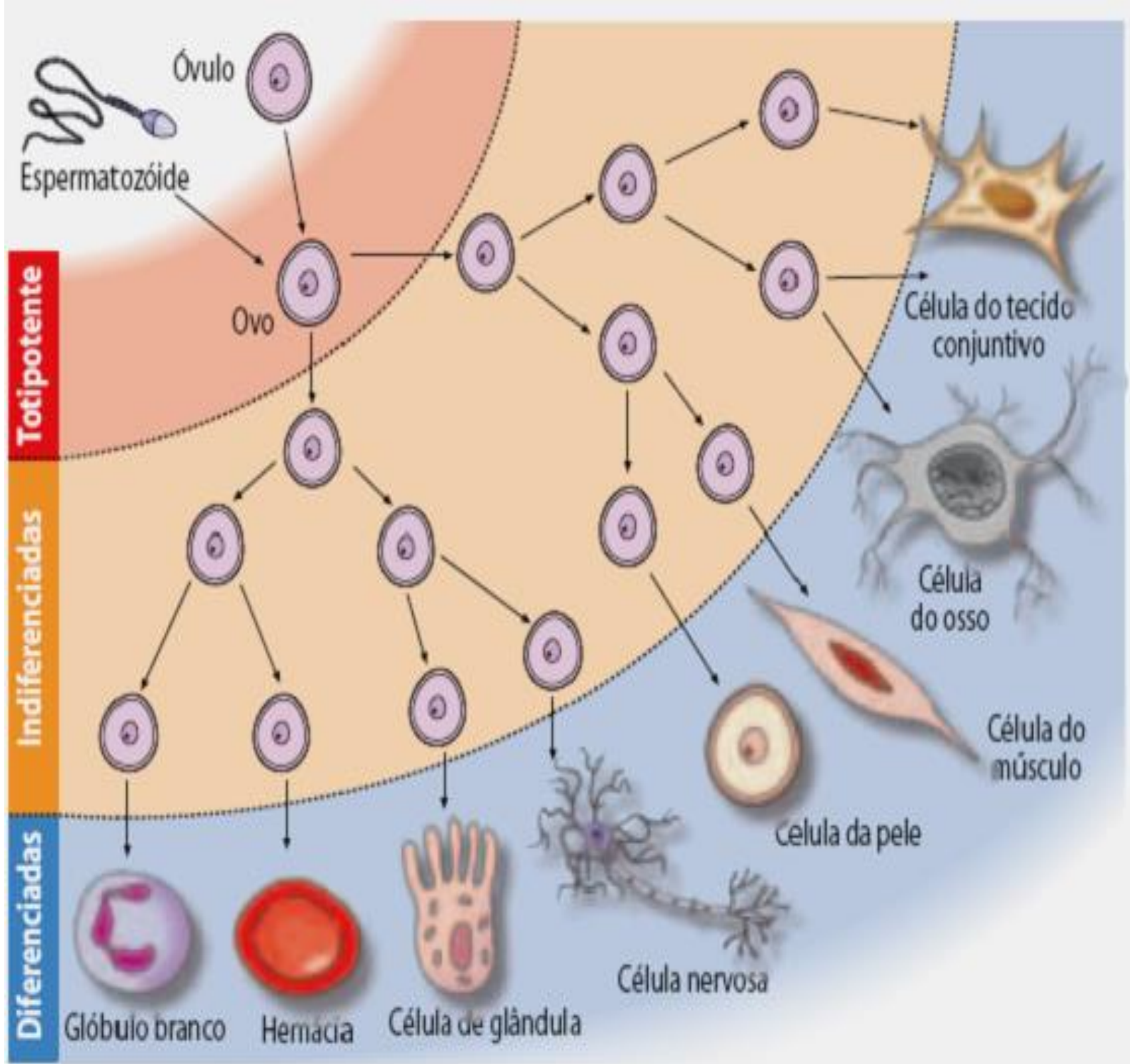

Fonte:http://www.netxplica.com/2015/disciplinas/biologiageologia1011/bio11_02.html acesso em 12 de maio de 2015

Porque células, com a mesma informação genética, têm formas e funções diferentes?

O que são células tronco? 


\section{ATIVIDADE 9 \\ Trabalhando com glossário}

\section{Caro professor (a)!}

Os glossários são compostos por termos técnicos e/ou específicos que poderão auxiliar a compreensão dos temas abordados. É preciso considerar que ao estudar um fenómeno novo além de o compreenderem, os alunos necessitam ser apresentados a uma nova linguagem específica, típica da ciência.

Para fazer um glossário, primeiro tenha em mente todas as palavras ou terminologias que necessitam explicação e então as organize por ordem alfabética. As explicações poderão ser breves ou um pouco mais extensas, dependendo da complexidade e da ênfase que se deseja condicionar o elemento a ser explicado. É uma atividade que o aluno pode fazer em casa.

Alguns exemplos:

Bactéria - Organismo unicelular, procarionte, isolado ou colonial, pertencente ao reino Monera

Citoplasma - Região da célula onde se encontram as organelas

Complexo de Golgi - Organela celular originado do retículo endoplasmático liso. Apresenta-se como um conjunto de vesículas achatadas e sobrepostas, distribuídas de forma irregular no citoplasma celular

Hemácias - Glóbulo vermelho ou eritrócito; célula vermelha do sangue; possui hemoglobina e é responsável pelo transporte de gás $\mathrm{O} 2$ e $\mathrm{CO} 2$

Leucócitos - Glóbulo branco; a célula branca do sangue; há diversos tipos de leucócitos, entre os quais podem ser citados os neutrófilos e os linfócitos; sua função é a defesa do organismo (fagocitose e produção de anticorpos).

Lisossomo - Organela presente no citoplasma de célula eucariontes, responsável pela digestão intracelular

Unicelulares - Composto por apenas uma célula.

Parede Celular - Envoltório relativamente rígido, externo à membrana plasmática, presente em alguns tipos de célula

Procariontes - Ou procarioto; tipo celular que não apresenta sistemas membranosos internos nem organelas; não há carioteca envolvendo o material hereditário 


\section{$\underline{\text { ATIVIDADE } 10}$}

O objetivo é conhecer as principais partes de um microscópio óptico, seu manuseio e funcionamento, também aprender a preparar lâminas "a fresco" com epitélio de escamas de cebola e da da mucosa oral, para podermos visualizar e poder diferenciar as estruturas ( parede celular, membrana plasmática, cloroplastos, núcleo, nucléolo) de cada tipo de célula eucariótica (vegetal e animal) .

\section{MATERIAL E MÉTODOS:}

\section{a)Observação das células da epiderme da cebola ( célula vegetal)}

Materiais utilizados

Lamina Lamínula

Corante azul de metileno $(0,3 \%)$

Pinça

Facas

cebola

Pipetas de Pasteur de plástico

Papel toalha

Metodologia:

cebola,- uma película delicada que recobre cada escama da cebola-

1- Cortou-se com uma faca a cebola e foi retirado com uma pinça, o epitélio da 2- Colocou-se o epitélio da cebola na lâmina 3- posteriormente foi colocado uma gota do corante azul de metileno 4- Cobriu -se a película com a lamínula 5- retira-se o excesso do corante com uma toalha de papel 6- Observou -se a lamina ao microscópio óptico 7- Os resultados obtidos foram anotados

\section{b)Observação da célula da mucosa bucal ( célula animal)}

Materiais e reagentes:

Laminas Lamínulas

Haste flexível

Corante azul metileno $(0,3 \%)$

Célula da mucosa bucal

Metodologia:

1- Com uma haste flexível obtém -se a mucosa bucal. 2- Espalha-se sobre a lâmina o material obtido, através da técnica do esfregaço; 3- Colocou-se uma gota do corante azul de metileno; 4- Cobriu -se com uma lamínula o material contido na lamina. 5- Observa-se a lamina ao microscópio óptico; 6- Anotam-se os resultados obtidos 


\section{Professor (a)}

Finalizando nosso diálogo gostaria de deixar um recorte do pensamento do biólogo Shedrake (2014, p.349) quando ele faz algumas reflexões a respeito da ciência no cotidiano das pessoas. Reproduzirei na íntegra um desses trechos:

"A ciência como a conhecemos é menos eficaz quando lida com aspectos subjetivos da realidade, ou quando tenta evita-los. A nossa própria percepção de qualidades como o perfume de uma rosa ou o som de uma banda foi reduzida ao mínimo, deixando apenas estruturas moleculares inodoras e a física das vibrações. A ciência tentou restringir-se a relações do tipo eu-objeto, uma visão de mundo em terceira pessoa. Ela fez o que pôde para deixar de fora as relações eu-você, experiências na segunda pessoa, bem como experiência em primeira pessoa, nossas experiências pessoais. Nossa vida interior- inclusive nossos sonhos, esperanças, amores, ódios, arrebatamentos, intenções, alegrias e tristezas - é reduzida a leituras de traçados de eletrodos, como no eletroencefalograma (EEG), alterações nos níveis de substâncias químicas das terminações nervosas ou imagens bidimensionais de tomografias computadorizadas cerebrais em telas de computador. Por esses meios uma mente se torna um objeto.

Durante a maior parte da história da humanidade, os seres humanos eram caçadores-coletores e só conseguiam sobreviver porque sabiam caçar e compreendiam profundamente os animais que caçavam. Só conseguiam sobreviver porque sabiam quais plantas eram comestíveis e onde e quando encontrá-las. Seu conhecimento foi útil, e ainda hoje nos beneficiamos de suas descobertas, e grande parte do nosso conhecimento sobre as propriedades medicinais dessas plantas era medicinal, adquiridas há muito tempo em culturas pré-científicas"

Bom trabalho!

Texto retirado do livro "Ciência Sem Dogmas” de Sheldrake Rupert 


\section{BIBLIOGRAFIA}

ALBERTS; Bray; Hopkin; Johnson; Lewis; Raff; Roberts \& Walter. Fundamentos da Biologia Celular. 3a ed. Porto Alegre. Artmed, 2011

AMABIS, J.M; MARTHO,G.R-Biologia das Células. São Paulo, Editora Moderna, 1999.

CORPO HUMANO - Novo Pensar. Autores: Demétrio Gowdak - Eduardo Martins. Editora FTD

DRIVE, R;ASOKO, H;LEACH, J; MORTIMER, E.F; SCOTT,P. Construindo conhecimento científico em sala de aula- química Nova na escola n ${ }^{\circ}$ 9, maio 1999.

MORTIMER, E. F. Linguagem e formação de conceitos no Ensino de Ciências. Belo Horizonte: Editora UFMG, 2006.

PLANO DE SEQUÊNCIAS DIDÁTICAS - Ministério da Defesa. Departamento De Educação e Cultura do Exercito, $8^{\circ}$ ano / Ensino Fundamental Área: Ciências da Natureza e suas Tecnologias-2014.

KRASILCHIK, M. Prática de ensino de biologia. São Paulo: Editora da Universidade de São Paulo, 2004.

LAVILLE, C.; DIONNE, J. A construção do saber: manual de metodologia da pesquisa em ciências humanas, tradução Heloísa Monteiro e Francisco Settineri. Porto Alegre: Artmed; Belo Horizonte: Editora UFMG, 1999, p.342. 
ANEXO: 
Anexo 1- Texto "Construindo conhecimento científico na sala de aula"

O ALUNO EM FoCO

PESQUISA NO ENSINO DE QUIMICA

\section{Construindo}

\section{conhecimento científico}

na sala de aula

\begin{abstract}
A seção "Pesquisa no ensino de química" relata investigaçóes relacionadas a problemas no ensino de química, explicitando os fundamentos teóricos e procedimentos metodológicos adotados na pesquisa $\mathrm{e}$ analisando seus resultados. A seçáo "Aluno em Foco" discute resultados de pesquisas sobre idéias informais dos estudantes, sugerindo formas de levar essas idéias em consideraçáo no ensino-aprendizagem de conceitos científicos. 0 presente artigo enfoca a importante temática da construçáo de conhecimento científico em sala de aula e a relaçáo entre as idéias científicas e idéias informais dos estudantes, razáo pela qual se inclui a traduçáo deste artigo para integrar as seçóes "Pesquisa em Ensino de Química" e "Aluno em Foco". A publicaçáo deste artigo também significa uma homenagem da comunidade de educadores químicos brasileiros à grande pesquisadora em ensino de ciências que foi Rosalind Driver, falecida em outubro de 1997.
\end{abstract}

processo de aprendizagem, idéias cientificas, idéias informais, pedagogia

$\mathbf{0}$ compromisso central de uma posiçáa construtivista - de que o conhecimento náo é diretamente transmitido mas construido ativamente pelo aprendiz - é compartilhado por diferentes tradiçóes de pesquisa no ensino das ciências. Uma dessas tradiçóes concentra-se na construçáo individual de significados e nas várias teorias informais que as pessoas desenvolvern sobre os fenômenos naturais (Carey, 1985; Carmichael et al., 1990; Pfundt e Duit, 1985), como resultado das interaçóes individuais dos aprendizes com os eventos físicos de sua vida diária (Piaget, 1970). A aprendizagem em sala de aula, a partir dessa perspectiva, é vista como algo que requer atividades práticas bem elaboradas que desafiem as concepçóes prévias do aprendiz, encorajando-o a reorganizar suas teorias pessoais. Uma outra tradiçáo descreve o processo de construçáo de conhecimento corno consequeência da aculturaçáo do aprendiznos discursos cienti- ficos (por exemplo, Edwards e Mercer, 1987; Lemke, 1990). Outros, ainda, vêem o processo como um aprendizado das práticas cientificas (Rogoff e Lave, 1984). O nosso próprio trabalho tem se concentrado no estudo de como os alunos recorrem a seu conhecimento informal e como este interage com as formas cientificas de conhecimento intro-

duzidas na sala de aula (por exemplo, Johnston e Driver, 1990; Scott, 1993; Scott et al., 1994). Existe uma variedade de descriçóes dos processos de construçáo do conhecimento. Parece ser necessário esclarecer essas perspectivas distintas e suas inter-relaçóes.

Uma outra questáo que precisa ser esclarecida entre os educadores em ciências é a relaçáo que vern sedo proposta entre a visáo construtivista da aprendizagem e suas implicaçóes

\author{
Rosalind Driver \\ Hilary Asoko \\ John Leach \\ Eduardo Mortimer \\ Philip Scott \\ Traduçào*: Eduardo Mortimer
}

pedagógicas. De fato, Millar (1989) afirma que perspectivas particulares sobre a aprendizagem náo resultam necessariamente em práticas pedagógicas especificas. Além disso, as tentativas de articular as abordagens "construtivistas' à didática das ciências (Driver e Oldham, 1986; Fensham et al., 1994; Osborne e Freyberg, 1985) têm sido criticadas com base no pressuposto de que tais praticas pedagogicas estáo fundamentadas em uma visáo empirista da natureza da ciência (Matthews, 1992; Osborne, 1993), argumento que será posteriormente analisado neste texto.

Neste artigo, vamos apresentar nossa visáo de como os vários fatores da experiência pessoal, da linguagem e da socializaçáo inter-relacionam-se no processo de aprendizagem das ciências em sala de aula e discutir as relaçóes problemáticas entre conhecimento cientifico, aprendizagem das ciências e pedagogia

\section{A natureza do conhecimento cientifico}

Qualquer relato sobre ensino e aprendizagem das ciências precisa levar em consideraçáo a natureza do conhecimento a ser ensinado. Embora trabalhos recentes sobre a natureza da ciência enfatizem que as práticas cientificas náo podem ser caracterizadas de modo unitário simplista, ou seja, 
que náo existe uma única "natureza da ciência' (Millar et al., 1993), existem alguns compromissos centrais ligados às práticas cientificas e ao conhecimento que têm implicaçóes para o ensino da ciência. Defendemos que, na educaçáo em cièncias, é importante considerar que o conhecimento cientifico é, ao mesmo tempo, simbólico por natureza e socialmente negociado. Os objetos da ciência náo sáo os fenômenos da natureza, mas construçóes deservolvidas pela comunidade científica para interpretar a natureza. Hanson (1958) fornece uma ilustraçáo eloqūente sobre a diferença entre os conceitos da ciência e os fenômenos do mundo, em seu relato sobre os esforços intelectuais de Galileu para explicar o movimento de queda livre. Durante vários anos Galileu realizou medidas de objetos em queda, representando a aceleraçáo em termos das mudanças na velocidade do objeto em uma dada distância, uma formulaçáo que levou a relaçóes complexas e deselegantes. Uma vez que ele começou a pensar em termos de mudança de velocidade em um dado intervalo de tempo, a aceleraçáo constante de objetos em queda se tornou evidente. A noçáo de aceleraçáo náo emergiu de forma náo problemática das observaçóes, mas Ihes foi imposta. O conhecimento cientifico em muitos domínios, sejanas explicaçóes do comportamento de circuitos elétricos, no fluxo de energia através de ecossistemas ou na rapidez das reaçóes químicas, consiste de entidades definidas formalmente e de relaçóes que se supóe existirem entre elas. O fato é que, mesmo em dornínios relativamente simples da ciência, os conceitos usados para descrever e modelar o domínio náo sáo revelados de maneira óbvia pela leitura do 'livro da natureza'. Ao contrário, esses conceitos sáo construçóes que foram inventadas e impostas sobre os fenômenos para interpretá-los e explicá-los, muitas vezes como resultado de grandes esforços intelectuais.

Uma vez que esse conhecimento tenha sido construido e acordado dentro da comunidade cientifica, torna-se parte da forma náo problemática de ver as coisas, aceita dentro dessa cornunidade. Como resultado, o mundo simbólico da ciência é hoje povoado por entidades como átomos, elétrons, lons, campos e fluxos, genes e cromossomos; ele é organizado por idéias como a da evoluçáo e inclui procedimentos de medida e experimentos. Essas entidades ontológicas e conceitos organizadores, assim como a epistemologia e as práticas das ciências a eles relacionadas, dificilmente seráo descobertas por individuos através de suas proprias observaçóes do mundo natural. O conhecimento cientifico, como conhecimento público, é construído e comunicado através da cultura e das instituiçóes sociais da ciência.

Existem estudos, na área de história e sociologia das ciências, que vềem o conhecimento que emerge da atividade dentro da comunidade cientifica como relativista e resultante exclusivamente de processos sociais (Colins, 1985; Latour e Woolgar, 1979). Além disso, essa posiçáo relativista argumenta que náo há como saber se esse conhecimento é um reflexo 'verdadeiro' do mundo, e que a noçáo de 'progresso' cientifico é, portanto, problemática Esse aparente 'irracionalismo' e relativismo das ciências é, no momento, motivo de controvérsia nos estudos sobre as ciências e na educaçáo em ciências. Mas uma perspectiva do conhecimento cientifico como socialmente construido náo implica logicamente uma posiçáo relativista. Ao propor uma ontologia realista, Harré (1986) sugere que o conhecimento cientifico é limitado pela própria estrutura do mundo tal como ele é, e que o progresso cientifico tem base empirica, mesmo que seja socialmente construldo e validado (urna posiçáo que consideramos convincente).

Quer se adote ou náo uma perspectiva relativista, a visáo do conhecimento cientifico como socialmente construído e validado tem implicaçóes importantes para a educaçáo em ciềncias. Isso significa que a aprendizagem das ciências envolve ser iniciado nas formas cientificas de se conhecer. As entidades e idéias cientificas, que sáo construidas, validadas e comunicadas através das instituiçóes culturais da ciência, dificilmente seráo descobertas pelos individuos por meio de sua propria investigaçáo emplrica; aprender ciências, portanto, envolve ser iniciado

\section{Rosalind Driver}

Quando o eu estava preparando esta traduçáo, fui co-

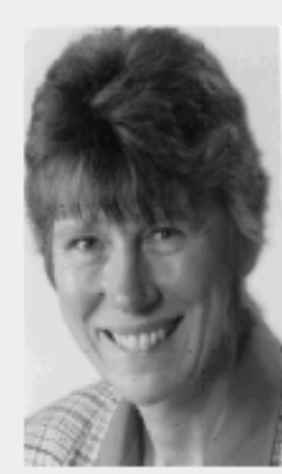
municado do falecimento da profa. Rosalind Driver, principal articuladora deste artigo. Ros foi uma da mais proeminentes figuras da educaçáo em ciências neste século. Seu trabalho com Jack Easley, publicado em 1978 no Studies in Science Education, sob o titulo de "Pupils and paradigms: a review of literature related to concept development in adolescent science students", é considerado um marco na criaçáo do programa de pesquisa sobre concepçóes alternativas dos estudantes, que dominou a cena na educaçáo em ciências na década de 80. Dinâmica e inquieta, Ros esteve sempre a frente do movimento construtivista no ensino de ciências e soube perceber como ninguém a crise que foi se instalando nesse programa de pesquisa a partir do fim da década de 80 . Este artigo representa uma tentativa de refletir sobre essa crise e sugerir novos rumos ao movimento.

Todos que tiveram a honra e o privilégio de conviver e trabalhar com a excelente figura humana que foi Ros Driver podem avaliar a dor que sua morte significou para seus amigos e colaboradores. Para seus leitores e admiradores nos quatro cantos do mundo, fica a sensaçáo de urna perda irreparável para a educaçáo em ciências. Espero que a publicaçáo deste artigo em português provoque nos leitores e leitoras a mesmas inquietaçóes, questionamentos e buscas de novos rumos que marcaram a vida de Rosalind Driver. 
pela interaçáso entre pares. No entanto, as interaçós dos aprendizes com as realidades simbollicas, com as ferramentas culturais da ciência, náo sáo substancialmente consideradas.

Além disso, ao ver a aprendizagem como algo que errvolve a substituiçấ de antigos esquemas de conhecimento por novos, essa perspectiva ignora a possibilidade de os individuos terem esquemas conceituais plurais, cada um apropriado a contextos sociais especificos. (Os cientistas, afinal, entendem perfaitamente o que sigrificam frases como "Feche a porta para o frio náo entrar"). No lugar de reequi braçoes sucessivas, argumenta-se que a aprendizagem pode ser mais bem caracterizada por construçes paralelas relacionadas a contextos especificos (Solomon, 1983). A noçáo de 'perfil epistemológico' de Bachelard (1940) 1968) pode ser útil aqui. Em vez de construir uma única e poderosa idéia, os individuos podem apresentar ma- ve a introduçáo em um mundo simbólico. Isso está bem explicitado na introduçáo de Bruner ao trabalho de Vygotsky:

O projeto Vygotskyano é descobrir o modo como os membros aspirantes de uma cultura aprendern de seus tutores, os vicários de sua cultura, a entender o mundo. Este mundo é um mundo simbólico no sentido de que ele consiste de sistemas de crenças conceitualmente organizados, delimitados por regras sobre as coisas que existem, sobre como atingir us objetivos e sobre o que dave ser valorizado. Náo existe nenhuma maneira, nenhuma mesmo, através da qual o ser humano poderia ter dominio desse mundo sem a ajuda e a assistencia de outras pessoas, pois, na verdade, esse mundo sáo os outros (Bruner, 1985, p. 32).

A partir dessa perspectiva, o cortheperfil concaitual dentro de dorninios especficos. Por exemplo, uma visáo contínua da matéria é normalmente adequada para lidar com as propriedades e o comportamento das substancias sólidas na vida cotidana. Perspectivas diferentes podem, entretanto, ser utilizadas. Uma visáo quântica da matéria é epistemologica e ontologicamente difererte de uma visio atornista, e ambas sáo diferentes de um modelo continuo. Essas tres perspectivas podem formar o perfil conceitual de urn individuo para us sólidos, e cada uma pode ser apropriada a um contexto diferente. Assim, um quimico que trabaha em uma reaçáa de sintese pode achar mais útil considerar os átomos particulas materiais do que um conjunto de singularidades matemáticas em campos de força (Mortimer, 1993).

\section{Aprendizagem das clenclas como construçào soclal do conhecimento}

Enquanto a perspectiva individual sobre a construçáo do conhecimento privilegia as experiencias flsicas e seu papel na aprendizagem das ciencias, uma perspectiva socioconstrutivista reconhece que a aprendizagem envole internalize o processo, ou se- ja, corvertendo-as em ferramentas para controle consciente.

Existe aqui uma questáo importante para a educaça em ciencias. Se a

construçáo do conhecimento for vista apenas corno processo indvidual, isso é semelhante ao que tern sido tradicionalmente identificado como aprendizagem por descoberta. Se, no entanto, os aprendizes tiverem que ter acesso aos sistemas de conhecimento da ciência, o processo de construçáa do conhecimento tern que ultrapassar a investigaçáo emplrica pessoal. Quem aprende precisa ter acesso náo apenas às experiencias flisicas, mas também aos conceitos e modelos da ciencia convencional. O desafio está em ajudar os aprendizes a se apropriarem desses modelos, a reconhecerern seus domínics de aplicabìidade e, dentro desses dominios, a serem capazes de usá-los. Se ensinar é levar ds estudantes às idéas cornvenciona's da ciencia, entáa a intervençáa do professor $e$ essencial, tanto para fornecer evidencias experimentais apropriadas como para disponibilizar para os alunos as ferramentas e convenḉos culturais da comuridade cientifica. O desafio é como alcançar com exito esse processo de enculturaçáo na rotina da sala de aula comum. Além disso, os desafios sáo especialmente importantes quando a perspectiva cientifica que o professor está apresentando é confitante com os esquemas de conhecimento prévio dos alunos.

\section{Idélas clentificas Informals e conhecimento de senso comum}

Os jovens possuem vários esquamas de conhecimento utilizados para interpretar os fenomenos com que se deparam no seu dia-a-dia. Esses esquemas sáo fortemente apoiados pela experiencia pessoal e pela socializaçáo em uma visáo de senso comum. Pesquisas feitas em todo o mundo já demonstraram que as idéias cientificas informais das crianças náo sáo total mentte idiossincráticas. Dentro de dominios especificos das ciências existem ma-
Em vez de construir uma única e poderosa ideia, os individuos maneiras diferentes de pensar, ou seja, um perfil conceitual dentro de domínios especificos neiras informais de modelar e interpretar os fenomenos que sáo encontrados entre crianças de diferentes palses, linguas e sisternas educacionais. Uma 
das áreas mais exaustivamente estudadas é o raciocínio informal sobre mecânica. Aqui existe uma concepçáo comum de que é necessário uma força constante para manter um objeto em movimento constante (Clement, 1982; Gunstone e Watts, 1985; Viennot, 1979). Essa noçáo difere da física newtoniana, que associa força à mudança na condiçáo de movimento, ou seja, à aceleraçáo. Entretanto, náo é difícil entender que experiências como empurrar objetos pesados ou pedalar uma bicicleta possam ser vistas como coerentes com a noçáo de que "movimento constante implica em força constante". Em outro domínio, aquele do raciocínio sobre as substâncias materiais, as crianças náo vêem problema em considerar a matéria algo que aparece e desaparece. Quando um tronco de madeira queima até ser reduzido a um amontoado de cinzas, as crianças afirmam que a matéria "se foi com o fogo" (Andersson, 1991). As crianças mais velhas podem reconhecer que existem produtos gasosos originários do fogo. No entanto, eles náo sáo vistos como substâncias, mas como algo que tem propriedades etéreas (Meheut et al., 1985). "Os gases, afinal, náo podem ter massa ou peso; se náo, por que náo caem?" De fato, para muitas crianças a idéia de que o ar ou um gás possa ter peso é totalmente implausível. Muitos chegam a postular que eles têm peso negativo, porque tendem a fazer as coisas subirem (Brook et al., 1989; Stavy, 1988). Um raciocínio semelhante é utilizado sobre o papel dos gases nos processos biológicos, como a fotossíntese, a respiraçáo e a degradaçáo (Leach et al., no prelo).

Esses sáo apenas alguns exemplos dos tipos de idéias informais que prevalecem no raciocínio de jovens e adultos. Em domínios como os aqui referidos, sustentamos que existem coisas em comum nas maneiras informais de raciocinar, em parte porque os membros de uma cultura compartilham formas de falar e de se referir a fenômenos específicos. Além disso, as maneiras como os individuos experimentam os fenômenos naturais sáo limitadas pela própria realidade.

No que tange às experiências do dia-a-dia das pessoas, as idéias informais sáo, na maioria das vezes, perfeitamente adequadas para interpretar e orientar as açóes. As fogueiras de fato queimam até virar periências do dia-ala das pessoas, as um monte de cinzas - uma maneira muito usada para livrar-se do lixo indesejado. Se você deseja que um piano continue a ser mover, você precisa de fato de empurrá-lo com um esforço constante. Náo é de
admirar que as idéias que sáo usadas e cuja utilidade é comprovada sejam entáo representadas na linguagem do dia-a-dia. Expressóes do tipo "leve como o ar" ou "o fogo consumiu tudo" refletem e apóiam idéias informais subjacentes. Argumentamos, portanto, que as idéias informais náo sáo apenas visóes pessoais do mundo, mas refletem uma visáo comum, representada por uma linguagem compartilhada. Essa visáo compartilhada constitui o 'senso comum', uma forma socialmente construída de descrever e explicar o mundo.

Durante a infância, as idéias das crianças se desenvolvem como resultado da experiência e da socializaçáo, transformando-se em visóes 'do senso comum'. Para crianças muito pequenas (entre 4 e 6 anos), o ar existe apenas como vento ou brisa - os pequeninos náo conceituam o ar como substância material. A noçáo do ar como 'coisa' normalmente torna-se parte dos modelos de mundo das crianças entre 7 e 8 anos. Essa coisa é entáo conceitualizada como algo que ocupa espaço, mas que náo tem peso, ou que tem um peso negativo ou a propriedade de se elevar ('upness' - Brook et al., 1989). Esse exemplo ilustra uma questáo muito mais geral: as entidades - o ar como coisa, por exemplo - que sáo tidas como reais pelas crianças podem ser bastante diferentes para crianças em faixas etárias diferentes Em outras palavras, as estruturas ontológicas cotidianas da criança desenvolvem-se com a experiência e com a utilizaçáo da linguagem dentro de uma cultura. Essa mudança corresponde ao que outros autores descrevem como uma reestruturaçáo radical das concepçóes específicas por domínio das crianças (vide Carey, 1985; Vosniadou e Brewer, 1992).

As formas 'de senso comum' de explicar os fenômenos, conforme exposto aqui, representam o conhecimento do mundo descrito dentro da cultura do dia-a-dia. Elas diferem do conhecimento da comunidade científica de várias maneiras. Obviamente, o senso comum e a ciência diferem nas entidades ontológicas que contêm. As entidades tidas como reais dentro do discurso do dia-a-dia diferem das entidades da comunidade científica Em segundo lugar, o raciocínio de senso comum, embora possa apresentar certa complexidade, também tende a ser tácito ou a náo ter regras explícitas. O raciocínio científico, por outro lado é caracterizado pela formulaçáo explícita de teorias que podem ser comunicadas e inspecionadas à luz da evidência. Em ciências, esse processo envolve vários cientistas comunicandose uns com os outros. Embora o conhecimento tácito tenha, inquestionavelmente, o seu lugar na ciência, a necessidade de ser explícito na formulaçáo de uma teoria é central para o empreendimento científico. Em terceiro lugar, o raciocínio do dia-a-dia é caracterizado pelo pragmatismo. As idéias sáo julgadas por sua utilidade para fins específicos ou em situaçóes específicas e, como tal, orientam as açóes das pessoas. A busca científica, por outro lado, tem o objetivo adicional de construir um quadro geral e coerente do mundo. O compromisso científico portanto, náo é satisfeito por modelos situacionalmente específicos, mas por modelos que tenham maior generalidade e escopo.

\section{Aprendizagem das ciências envolvendo processos individuais e sociais}

Vamos considerar agora o que vemos como as implicacóóes das distin- 
Raios de luz: negociando "novas ferramentas conceituais" - novas entidades ontológicas

Uma classe de alunos entre 8 e 9 anos de idade participou de uma série de aulas introdutórias sobre a luz (vide Asoko, 1993). As crianças nessa idade tendem a considerar a luz como fonte ou efeito (Guesne, 1985), mas têm menos possibilidade de conceituar a luz como algo que existe no espaço e que se desloca a partir de uma fonte. 0 professor, Michael, estava interessado em ajudar a turma a desenvolver a idéia de que a luz viaja pelo espaço e que se desloca em linha reta. Uma vez estabelecida a concordância de que a luz viaja em linha reta, ele planejou apresentar a representaçáo convencional dos 'raios' de luz.

A princípio, o professor Michael convidou a classe a pensar sobre a luz da sala de aula, e todas as crianças concordaram que se tratava da luz do sol. A seguir ele explorou com elas essa noçáo um pouco mais, perguntando de onde vem a luz do sol.

Aluno 1: Do sol.

Michael: Quer dizer que a luz que está entrando naquela janela veio do sol? (várias respostas simultâneas)

Aluno 2: Vem do calor, porque é táo quente que faz uma luz brilhante.

Michael: Entáo como é que ela chega aqui? Se é a luz do sol, como é que pode estar aqui também? Martyn?

Aluno 3: Porque o sol está brithando sobre nós.

Michael: Mas ele está a $93 \mathrm{mi}-$ Ihóes de milhas daqui - entáo como é que a luz do Sol pode estar aqui nesta mesa?

Aluno 4: É por causa da camada de ozônio? (Seguiu-se uma curta interaçáo entre eles, em que vários alunos deram suas idéias sobre o buraco na camada de ozônio que permitia que mais luz do sol passasse, e entáo Michael recolocou sua pergunta).

Michael: Mas como é que a luz do sol chega até aqui?

Aluno 5: Ela viaja até aqui.

Michael: Coulton disse, e essas sáo suas palavras exatas, que "ela viaja até aqui". Em outras palavras, a luz se move do Sol até aqui..

Aluno 5: Sim.

Michael: 93 milhóes de milhas. Está certo?

Alunos: Sim (coro de muitas vozes)

Nessa interaçáo, Michael indicou que a idéia do sol brilhando sobre nós poderia ser mais bem elaborada $e$, com as contribuiçóes da turma, focalizou a idéia da luz como algo que viaja de sua fonte, percorrendo o espaço. Sua interaçáo com a classe, à medida que a idéia foi sendo explorada, fornece uma indicaçáo de que essa é uma idéia geralmente aceita como plausível, um aspecto importante na construçáo conjunta do conhecimento em sala de aula.

A idéia de que a luz viaja foi desenvolvida um pouco mais através de uma atividade prática feita em grupos. Cada grupo de três a quatro crianças recebeu um jogo de equipamentos contendo uma lâmpada de $12 \mathrm{~V}$, colocada em uma posiçáo central sob uma caixa de cartolina octogonal de aproximadamente $35 \mathrm{~cm}$ de diâmetro, colocada sobre uma grande folha de papel. Foi cortada uma fresta de $12 \mathrm{~cm}$ de altura por $0,5 \mathrm{~cm}$ de largura em cada uma das oito faces. Foi entáo pedido às crianças para pensar sobre o que veriam quando a luz fosse acesa e para desenhar, na folha de papel, o que esperavam ver. Quase todas as crianças desenharam linhas num ângulo de 90 graus em relaçáo às faces, a partir da fresta, para indicar o caminho da luz. As linhas variavam em comprimento, de 2 a $3 \mathrm{~cm}$ até aproximadamente 30 $\mathrm{cm}$. Quando todas as crianças haviam feito pelo menos uma previsáo, todas as lâmpadas foram acesas simultaneamente na sala escura. O efeito espetacular causou certa empolgaçáo e náo pouca surpresa, quando as crianças perceberam que, em vez de percorrer apenas uma distância curta, os raios de luz continuaram por toda a folha, podendo ser vistos, num plano vertical, quando chegavam a uma superfície como a parede ou os corpos das crianças.

Michael reuniu a turma para discutir suas observaçóes. Ele desenhou, no quadro, o plano da caixa octogonal. Traçando uma linha para representar a trajetória da luz, ele comentou que todos haviam feito previsóes sobre a posiçáo da linha que estavam de acordo com o que eles tinham visto, mas acrescentou que várias pessoas na sala acharam que a luz iria parar.

Michael: Está certo?

Aluno 1: Náo, ela continua.

Michael: Ela continua. Quanto mais ela continuaria?

Aluno 2: Até o final. Ela continua toda a vida

Aluno 3: Continua toda a vida, isto...

Aluno 4: Ela náo pode parar. Você náo pode parar a luz sem desligá-la.

Nessa sequêencia, a noçáo de que a luz "continua toda a vida" novamente é interpretada como um discurso compartilhado. Michael entáo convidou as crianças a desenhar mais linhas sobre o seu desenho a fim de mostrar para onde vai a luz. Depois que elas terminaram, Michael começou a usar as palavras raio de luz para descrever a trajetória da luz.

Nesse conjunto de seqüências, Michael estava introduzindo às crianças, por meio do discurso, a maneira cientifica de ver as coisas, tornando essa visáo plausível no contexto de uma experiência memorável. Tendo se convencido de que as crianças tinham uma representaçáo mental para "o caminho pelo qual a luz viaja", ele introduziu a convençáo ou representaçáo simbólica do raio de luz, uma ferramenta cultural que seria utilizada em aulas subseqüentes. Ao longo de toda a sequêencia, foi surgindo uma estória coerente, uma estória que Michael verificava, através de feedbacks, ser comum a toda a turma. Esse processo de desenvolver um significado compartilhado entre professor e alunos é central àquilo que Edwards e Mercer (1987) chamam de conhecimento comum na sala de aula. Esse conhecimento comum ou discurso compartiIhado passou a se referir a uma nova estrutura ontológica sobre a luz, uma estrutura na qual a luz viaja, e viaja em linha reta (representada simbolicamen- 
te por 'raios de luz') por longas distâncias.

A pressão do ar: estruturando (scaffolding) "uma nova maneira de explicar" - conflito entre o senso comum e a perspectiva cientifica

0 processo pelo qual os alunos desenvolvem novas maneiras de explicar podem envolver interaçóes dialógicas entre professor e alunos ou entre pequenos grupos de alunos. Nessas interaçóes, o adulto (ou um colega mais competente) fornece aquilo que Bruner (1986) chamou de 'andaime' (scaffolding) para a aprendizagem dos alunos enquanto eles constroem novos significados para si mesmos.

Numa seqüência instrucional sobre a pressáo do ar entre alunos de 11 e 12 anos (Scott, 1993), o professor desenvolveu, por meio de demonstraçóes e conversa com a classe, uma nova maneira de explicar vários fenômenos sim-

ples (como, por exemplo, por que uma garrafa plástica murcha quando o ar é retirado de dentro dela). Essa nova maneira de explicar baseava-se nas diferenças entre a pressáo do ar dentro e fora da garrafa. Foi pedido à turma para trabalhar em grupos a fim de usar essa idéia de diferença de pressáo para explicar outros fenômenos - por exemplo, como borrachas de sucçáo, a exemplo dos desentupidores de pia, grudam em superfícies lisas ou como um líquido pode ser sugado para uma pipeta.

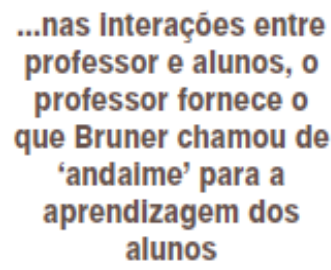

Nas passagens que se seguem, vemos exemplos de um adulto experiente tentando 'andaimear' (to scaffold) o raciocínio dos estudantes em termos do modelo de diferença de pressáo. Vemos também as maneiras como as teorias informais dos alunos, como por exemplo a idéia de que "o vácuo suga", influenciam na formaçáo de sentido pelos indivíduos.

Christa e Adele completaram uma atividade com as borrachas de sucçáo e ficaram surpresas com a força que precisaram fazer para retirá-las de uma superfície lisa. Elas entáo discutiram sua explicaçáo para o fato:

Christa: É uma superfície lisa e náo existe ar na borracha, entáo há menos ar dentro do que fora, por isso ela gruda.

Adulto: Entáo, o que é que empurra... o que é que faz grudar?

Christa: $\mathrm{O}$ ar.

Adele: A sucçáo.

Adulto: $\mathrm{O}$ que é sucçáo?

Adele: $\hat{E}$ algo que puxa... algo que puxa para baixo.

Adulto: Uns minutinhos atrás, você disse que tinha a ver com o ar empurrando aqui fora.

Adele: Sim.

Adulto: Entấo você também disse que tinha a ver com sucçáo. Trata-se da mesma explicaçáo, ou sáo explicaçóes diferentes?

Adele: Sáo quase... (Adele náo tem certeza e interrompe sua fala).

O adulto entáo lembrou as duas meninas da demonstraçáo anterior do colapso da garrafa plástica, que elas explicaram em termos de diferença na pressáo do ar dentro e fora. As meninas entáo voltaram a pensar no caso das borrachas de sucçáo.

Adulto: Agora, onde é que estáo a parte de dentro e de fora?

Adele: Bem... esta é a parte de dentro (indica a parte de baixo da borracha de sucçáo)

Adulto:Sim... certo.

Adele:É, e esta é a parte de fora.

Adulto: Ok. - Você pode usar a mesma explicaçáo usada para a garrafa, para poder explicar o que acontece aqui? ( $\mathrm{O}$ adulto volta a se referir à garrafa plástica que murchou).

Adele: Tem alguma coisa a ver com gravidade?

Adulto: Por que você está dizendo isto?

Adele: Puxando para baixo.

Após uma conversa adicional, Adele e o adulto concordaram que a gravidade pode estar agindo mesmo quan- do náo existe ar, e que sáo, portanto, coisas diferentes. Eles continuaram a pensar nas borrachas de sucçáo:

Adele: Está agarrado no fundo. ele [o ar] sai todo pelas laterais.

Adulto: Tudo bem, mas e o ar do lado de fora?

Christa: $\mathrm{O}$ ar de fora está empurrando para baixo

Adele: Entáo fica difícil puxar para cima.

Neste trecho, o adulto estruturou 0 curso do raciocínio, primeiro lembrando às meninas da explicaçáo que a turma construiu para o fenômeno ocorrido com a garrafa plástica e, a seguir, ajudando-as a fazer a ligaçáo com o caso da borracha de sucçáo ao levá-las a pensar no ar dentro e fora da borracha.

Logo em seguida, Adele levantou uma outra questáo:

Adele: Como é que quando você prende a borracha, e entáo você puxa para um canto da mesa e ela solta?

Adulto: Ah, esta é uma ótima pergunta. Vocês querem analisar isto um minutinho?

Adele: É que.

Christa: Náo, deixa eu mostrar o que acontece. É o ar, ele consegue entrar de volta, náo consegue?

Adele: É, ele volta para dentro, entáo o ar empurra para cima, náo é?

As duas: $\mathbf{E}$

Aqui, o adulto retirou o apoio ou scaffolding, tornando-se apenas um espectador interessado, e as próprias garotas usaram com confiança a explicaçáo baseada na diferença de pressáo. No entanto, uma pergunta final de Christa sugere que ainda pode haver problemas:

Adulto: Agora... (pausa longa) vocês têm alguma pergunta a respeito?

Christa: Por que... por que o ar empurra para baixo... quando o ar sai pelas laterais? Por que 0 ar empurra para baixo?

A pergunta de Christa sugere que embora ela tivesse tido êxito (com o 
apoio do adulto) em construir a explicaçáo com base na diferença de pressáo para esse caso, a situaçáo ainda náo é plausível para ela ("Por que o ar empurra para baixo?"). Na verdade, é bastante improvável que qualquer experiência ou explicaçáo anterior sobre o ar estático pudesse apoiar a idéia de que ele exerce tanta pressáo. A nova maneira de explicar desafia as idéias dos alunos sobre aquilo que 0 ar pode e náo pode fazer; desafia suas ontologias pessoais sobre $\mathrm{o}$ ar.

Os exemplos aqui apresentados chamam a atençáo para o ponto fundamental de que domínios diferentes da ciência envolvem tipos diferentes de aprendizagem. No primeiro exemplo, os jovens alunos pareciam ter pouca dificuldade em compreender e acreditar que a luz viaja e persiste, a menos que seja bloqueada. Eles adotaram o discurso científico e usaram as idéias de forma produtiva. A situaçáo no segundo exemplo parece ser bastante diferente. O professor havia envolvido as alunos nas atividades e no discurso a fim de apoiá-las na construçáo da visáo científica, e mesmo assim vemos as alunas passando por dificuldades para tornar aqueles modelos da ciência significativos e apropriá-los à realidade de cada uma. Sugerimos que essas diferenças nas reaçóes dos alunos podem, em parte, ser explicadas ao se considerar as demandas ontológicas e epistemológicas de aprendizagem nos domínios distintos da ciência que estáo sendo estudados. No entanto, 0 que é comum em ambos os casos é o processo pelo qual o professor, familiarizado com o modo de ver científico, torna acessiveis aos alunos as ferramentas culturais da ciência, apoiando a (re)construçáo de suas idéias por meio do discurso sobre eventos físicos comuns.

\section{Resumo e comentários finais}

$A$ visáo de que o conhecimento científico é socialmente construído, validado e comunicado é central neste artigo. Apresentamos uma perspectiva de aprendizagem das ciências como processo de enculturaçáo e náo de descoberta, argumentando que o estudo empírico do mundo natural náo resultará em conhecimento científico porque o conhecimento científico é, por natureza, discursivo. Mostramos que os alunos de ciências possuem representaçóes cotidianas sobre os fenômenos que a ciência explica. Essas representaçóes sáo construídas, comunicadas e validadas dentro da cultura do dia-a-dia. Elas se desenvolvem à medida que os individuos convivem dentro de uma cultura. Mostramos que existem diferenças epistemológicas e ontológicas entre o raciocínio cotidiano e o raciocínio científico. Embora a aprendizagem das ciências envolva interaçóes sociais, no sentido de que as ferramentas culturais da ciência precisam ser apresentadas aos alunos, defendemos a posiçáo de que os individuos precisam entender de forma pessoal as maneiras de ver o mundo que lhes foram apresentadas. Se as representaçóes cotidianas de certos fenômenos naturais forem muito diferentes das representaçóes científicas, a aprendizagem acaba sendo difícil. Já argumentamos que a relaçáo entre as visóes de aprendizagem e a pedagogia é problemática e que náo existem regras simples para a prática pedagógica que emergem de uma visáo construtivista da aprendizagem. Existem, no entanto, aspectos importantes do processo de mediaçáo que podem ser identificados. Para que os alunos adotem formas científicas de conhecer, é essencial que haja intervençáo e negociaçáo com uma autoridade, normalmente o professor. Nesse aspecto, o ponto crítico é a natureza do processo dialógico. O papel do professor, como autoridade, possui dois componentes importantes. 0 primeiro deles é introduzir novas idéias ou ferramentas culturais onde for necessário e fornecer apoio e orientaçáo aos estudantes a fim de que eles próprios possam dar sentido a essas idéias. O outro é ouvir e diagnosticar as maneiras como as atividades instrucionais estáo sendo interpretadas, a fim de subsidiar as próximas açóes. $\mathrm{O}$ ensino visto nessa perspectiva é, portanto, também um processo de aprendizagem para o professor. Aprender ciências na sala de aula requer que as crianças entrem numa nova comunidade de discurso, numa nova cultura; o professor é o guia, quase sempre pressionado, des- sa excursáo, que faz a mediaçáo entre o mundo cotidiano das crianças e o mundo da ciência.

$\mathrm{O}$ que foi apresentado aqui difere fundamentalmente do programa educacional positivista, cuja ênfase reside na racionalidade técnica e na apresentaçáo náo-problemática do conhecimento a ser adquirido. Participando das atividades discursivas das aulas de ciências, os alunos váo sendo socializados nas formas de conhecimento e nas práticas da ciência escolar. Isso representa uma grande demanda para os educadores: O desafio está em criar, entre os alunos, uma perspectiva crítica sobre a cultura científica. A fim de desenvolver tal perspectiva, os alunos precisaráo estar conscientes dos objetivos variados do conhecimento científico, de suas limitaçóes e das bases sobre as quais se assentam suas asserçóes. Um desafio crucial para o cotidiano da sala de aula é, portanto, transformar esses aspectos epistemológicos no foco explícito do discurso e, assim, socializar os alunos na perspectiva crítica da ciência como forma de conhecimento.

Rosalind Driver foi professora titular de ensino de ciências na Faculdade de Educaçáo da Universidade de Leeds, Reino Unido, onde Hilary Asoko, John Leach $\ominus$ Philip Scott sáo professores de ensino de ciências. Em 1995 Rosalind Driver assumiu a posiçáo de professora titular do King's College, em Londres. Todos as quatro têm em cornum o interesse no ensino e aprendizado das ciências, com um enfoque especlfico sobre o deservolvimento da compreensáo de conceitos, tendo sido membros do CLIS (Chidren's Leaming in Science Hesearch Group) atualmente LIS. Eduardo Mortimer é professor adiunto da Faculdade de Educacáo da Universidade Federal de Minas Gerais, Brasil, também interessado no deservolvimento da compreensáo de conceitos nas ciências.

^Este artigo foi originalmente publicado em Educational Research, v. 23, n. 7. p. 5-12, 1994 . Sua traduçác foi autorizada pela American Educational Research Association.

\section{Agradecimentos}

Os autores agradecem os comentários feitos por Robin Millar a uma versáo anterior deste trabalho, bem como as valiosas sugestóes feitas por revisores anônimos.

\section{Nota do tradutor}

1. No original, "is burnt away". É difícil encontrar uma expressáo semeIhante em português. 
